\title{
WHAT HAPPENS WHEN THEY \\ LEAVE? \\ THE SOCIAL IMPACT OF \\ MIGRATION ON THE PHILIPPINES
}

\author{
by
}

\section{Ashifa Kassam}

A thesis submitted to the Faculty of Graduate Studies and Research in partial fulfillment of the requirements for the degree of

\section{Master of Journalism}

School of Journalism and Communication

\author{
Carleton University \\ Ottawa, Ontario \\ May 2008
}

(C) Ashifa Kassam 2008 


$\begin{array}{ll}\begin{array}{l}\text { Library and } \\ \text { Archives Canada }\end{array} & \begin{array}{l}\text { Bibliothèque et } \\ \text { Archives Canada }\end{array} \\ \begin{array}{l}\text { Published Heritage } \\ \text { Branch }\end{array} & \begin{array}{l}\text { Direction du } \\ \text { Patrimoine de l'édition }\end{array} \\ \begin{array}{l}\text { 395 Wellington Street } \\ \text { Ottawa ON K1A 0N4 } \\ \text { Canada }\end{array} & \begin{array}{l}\text { 395, rue Wellington } \\ \text { Ottawa ON K1A 0N4 } \\ \text { Canada }\end{array}\end{array}$

Your file Votre référence ISBN: 978-0-494-40652-6

Ourfile Notre référence

ISBN: 978-0-494-40652-6

NOTICE:

The author has granted a nonexclusive license allowing Library and Archives Canada to reproduce, publish, archive, preserve, conserve, communicate to the public by telecommunication or on the Internet, loan, distribute and sell theses worldwide, for commercial or noncommercial purposes, in microform, paper, electronic and/or any other formats.

The author retains copyright ownership and moral rights in this thesis. Neither the thesis nor substantial extracts from it may be printed or otherwise reproduced without the author's permission.
AVIS:

L'auteur a accordé une licence non exclusive permettant à la Bibliothèque et Archives Canada de reproduire, publier, archiver, sauvegarder, conserver, transmettre au public par télécommunication ou par l'Internet, prêter, distribuer et vendre des thèses partout dans le monde, à des fins commerciales ou autres, sur support microforme, papier, électronique et/ou autres formats.

L'auteur conserve la propriété du droit d'auteur et des droits moraux qui protège cette thèse. $\mathrm{Ni}$ la thèse ni des extraits substantiels de celle-ci ne doivent être imprimés ou autrement reproduits sans son autorisation.
In compliance with the Canadian Privacy Act some supporting forms may have been removed from this thesis.

While these forms may be included in the document page count, their removal does not represent any loss of content from the thesis.
Conformément à la loi canadienne sur la protection de la vie privée, quelques formulaires secondaires ont été enlevés de cette thèse.

Bien que ces formulaires aient inclus dans la pagination, il n'y aura aucun contenu manquant.

\section{Canada}




\begin{abstract}
The Philippines has consistently ranked as one of the world's top suppliers of migrant workers, with Filipinos arriving in droves on the doorsteps of developed countries to work both legally and illegally. While their impact on the global economy has been well-documented, there has been little analytical journalism examining the social consequences of this mass exodus on Filipinos and Filipino culture. Whether they cross borders to work as domestic workers, teachers or nurses, migration causes immediate and long-term hardships that range from the emotional wrench of family separation to brain drain from the country. This thesis explores migration's footprint on the politics and economics of the Philippines. As the majority of those leaving the Philippines are women, the thesis also documents the effects of this gendered migration pattern, including the experiences of domestic workers who come to Canada.
\end{abstract}




\section{Acknowledgments}

This thesis would not have been possible without the insight, patience and wisdom of Dr. Barbara Freeman. Thanks must also go to the many Filipinos who opened their hearts and their homes to me in telling their stories. 
Introduction

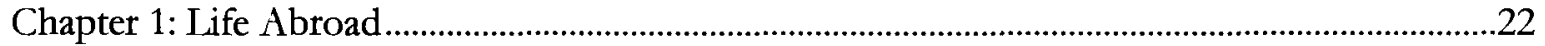

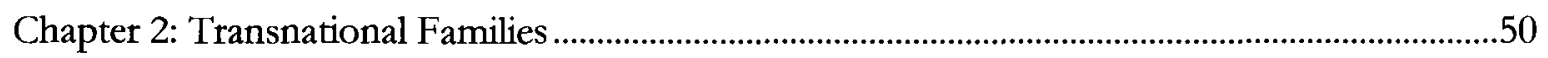

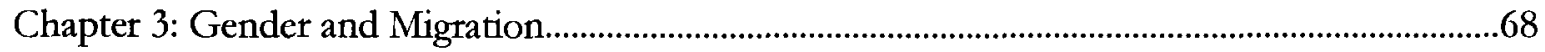

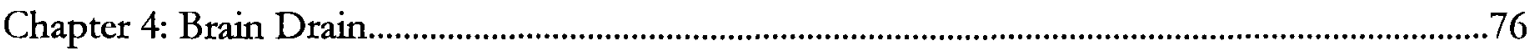

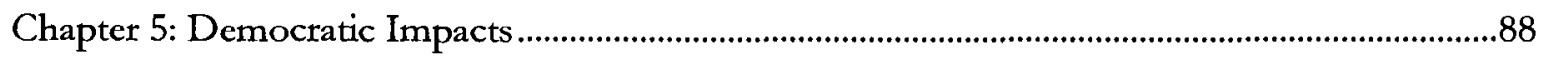

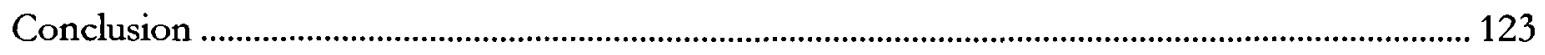

Interviews …

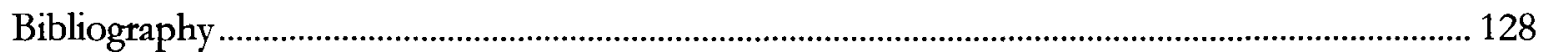




\section{Introduction}

At the Manila International Airport, there are brown, cardboard boxes everywhere. They outnumber the luggage of travellers several times over; giant cartons filled to the brim with gifts from places that most Filipinos can only dream of. Their contents -- French wines, Belgian chocolates, Canadian maple syrup, American clothing and any other luxuries that might fit inside -- are betrayed by the label reading, Balikbayan. This label grants the contents an easy pass through customs.

The term Balikbayan refers to a Filipino who lives overseas. They come home either permanently or just for a visit - in numbers large enough to merit their own category on immigration forms. As box after box tumbles onto the baggage claim conveyer belt, many are seized by their senders. But some Balikbayan cartons arrive unaccompanied, sent with high hopes that honest airport staff will make sure that they arrive at their final destinations. One box swings around the conveyor belt several times. Along with its telltale Balikbayan label, it's addressed to the Dumagues family who live in a remote seaside village in northern Philippines.

The sender is Lorena Dumagues, who left home six years ago to become a domestic worker in Hong Kong. This shy, demure woman of 27 years, the youngest member of her family, is a flesh and blood manifestation of the Philippines' latest development strategy - the export of human capital. "It's not politically correct to say that you're exporting people," the labour secretary of the Philippines, Patricia Santo 
Tomas, once told reporters, "but it's part of globalization and I like to think that countries like ours, rich in human resources, have that to contribute to the rest of the world."'

It's a new twist to an old story. Every day, all over the world, people migrate from one place to another with the hope of improving their lives. They move from rural to urban areas, from poor provinces to rich ones and from developing nations to wellestablished ones. Whether for job opportunities, the chance to obtain an education or to escape oppression, people change their lives every_day through migration.

This thesis, using analytical journalism, will explore the social consequences of migration from the Philippines, a country where close to 3,000 people a day leave to work abroad. ${ }^{2}$ While journalists have reported on the economic benefits of migration, few have considered its social impacts. A small number of academics are researching migration's social costs, but their work is often narrow in scope. This thesis will use their work as a foundation, but rely strongly on personal narratives to tell the larger, unheard story of the multiple impacts migration is having on the Philippines. Several dimensions of Filipino life will be considered, including life abroad, especially in Canada, the trials of family separation and brain drain from the country. As the majority of those migrating from the Philippines are women, the effects of this gendered migration will be explored, as well as the democratic impact of having an entire country dreaming of life abroad. Finally this thesis will weigh the question being asked by development theorists around the world; is this migration leading to development? Is the Philippines, overall, gaining or losing by exporting its labour to countries around the world?

\footnotetext{
'quoted in David Diamond, "One nation, overseas," Wired.com, 10 June 1999, 16 April 16, 2008 $<$ http://wired.com/wired/archive/10.06>.

${ }^{2}$ Glenis Balangue, "OFW Remittances: Lifeblood of the Economy?" IBON Facts \& Figures 29.1(2006):4.
} 
These questions need to be asked, as an unprecedented surge of people around the world are migrating across borders and launching themselves into a whole new culture, language and way of life. In the last 30 years, the number of international migrants has more than doubled from 75 million to 200 million. $^{3}$

Necessity propels many of them. In 2006, migrant workers sent an estimated $\$ 300$ billion -- nearly three times the world's foreign-aid budgets combined -- from developed economies to their home countries through official channels along with an estimated 20 to 50 per cent more by unofficial means, such as friends and family who were returning home. ${ }^{4}$ It is exactly this combination of bravery, necessity and hope for a better life that brought Dumagues to Hong Kong.

In this city of nearly seven million people, nine per cent of all households employ foreign live-in maids. The majority of these domestic workers are Filipino women, with an estimated 140,000 living and working in Hong Kong. Sunday is their governmentsanctioned day off and the central district's markets that cater specifically to Filipinos draw thousands of maids using their precious free time to run errands, socialize with each other in their mother tongue of Tagalog and relax.

They come from different parts of the Philippines, but their stories are nearly always identical. Frustrated by the lack of jobs and consistent poverty in their homeland, the promise of money lures them to work in Hong Kong. For a cut of their eventual salary, recruiting agencies in the Philippines will secure them a two-year contract with a household seeking a domestic worker, obtain a working visa for them and cover the cost

\footnotetext{
${ }^{3}$ Report of the Global Commission on International Migration, Migration in an interconnected world: New directions for action, (Switzerland: SRO-Kundig, 2005) vii.

${ }^{4}$ Ibid., vii.
} 
of their flight. They get room and board plus the equivalent of about US $\$ 475$ per month, the majority of which they send home to their families in the Philippines.

In Hong Kong's soaring rent market, apartments are tiny and often the domestic worker's space is minuscule. Dumagues lives out her life in this world-class city in a closet-sized room of her employer's $18^{\text {th }}$ floor apartment. The extravagant apartment, with its glistening hardwood floors and three full bathrooms is worlds away from the small fishing village in the Philippines that she calls home. "Sometimes I can't believe that I live here," she says, pointing to the breathtaking view of Hong Kong's harbour from the living room windows. "I just shake my head when I think of where I grew up."

Her family's reliance on the sea for their livelihood accustomed her to a hard life where food and water were often scarce and luxuries were unheard of. After graduating from high school, she couldn't afford to attend university and couldn't find any work in her village. "I thought maybe I could start a business or find a job in Manila. After one year of trying, I realized nothing was happening."

Her older sister, earlier frustrated by the same dilemma, had moved to Hong Kong to become a domestic worker and was earning good money. Motivated by her experience, Dumagues followed her. She left behind her aging parents, her boyfriend who works as a teacher in their village and everything she had ever known in her life, with hopes that the money she would earn could compensate. She was terrified, but also excited to see Hong Kong, to experience a different culture and, most importantly, to help lift her family out of the poverty that had become their daily reality.

The first family Dumagues worked for had two children and owned a restaurant. They forced her to look after the youngsters, help out in the restaurant and take care of all 
of the domestic chores. Twenty-hour workdays became the norm. While the family otherwise treated her well, she was relieved when the contract expired and her next one placed her in a home with an elderly woman. These days she works only 14 hours a day, Monday though Saturday, rising at 6 a.m. to prepare breakfast, cook elaborate lunches and dinners from scratch, hand-wash all of the laundry, scrub every inch of the apartment and wait on her employer's friends and family until 10 p.m.

Having done much sightseeing during her first few years in Hong Kong, Dumagues often spends her day off at a rest house for domestic workers operated by a non-profit agency. Here she has the chance to catch up on her sleep, meet with her sister and phone her friends and family back home.

It's been four years since she switched employers and much in her life has changed. Between contracts she returned home and married her boyfriend. Her sister went home for good, only to return to Hong Kong a few months later. "She missed Hong Kong and she couldn't make any money at home," says Dumagues, shaking her head. "I wonder if that will happen to me." She's hoping to head home in two years so that she can live with her new husband for the first time ever.

In spite of all the hard work, Dumagues is deeply appreciative of the opportunities she has been granted as a domestic worker. "Otherwise I would have never seen Hong Kong. I would have never left the Philippines. And I couldn't have helped my family."

Her only complaints about the job are the long hours and the constant loneliness, as she is only able to socialize with others on Sundays. The other six days of the week she is relegated to inside the house with her employer who has little interest in speaking to her. 
"But I have been very, very lucky," she says, her eyes widening. She knows a few domestic workers who have been beaten or sexually abused by their employers. Their only choices are to quit and be deported back to the Philippines or to suffer through the harsh working conditions quietly for the sake of the money. Other women painfully tell their stories of working in Hong Kong solely to support their own children in the Philippines, describing an ironic reality where a mother's only choice is to separate from her children in order to afford to provide them with three meals a day and fund their education.

But when asked if she would rather be in the Philippines, Dumagues nods shyly. She loves her home, misses her family and dreams of going back someday to have children and settle down. But for now, on an income of US\$475 a month, her dreams will have to be set aside.

The United Nations estimates that there are almost 200 million migrants around the world, a population equivalent to that of Brazil, the world's fifth largest country. This number has more than doubled since 1980 , when the UN estimated that around 78 million people resided in a country other than where they were born. ${ }^{5}$ The reasons for migration vary as widely as the countries of origin; refugees flee lives of terror, retired Europeans abandon the cold while second-generation Canadians find better opportunities in their parents' homeland. Many of these are permanent migrants, the relatively lucky

\footnotetext{
${ }^{5}$ Hania Zlotnick, "The South-to-North Migration of Women," International Migration Review 29.1(1995):230.
} 
ones for whom the immigration game has been beneficial enough to give them a new home, new opportunities and potentially even new citizenship.

But around the world, millions like Dumagues play a different game. They are the world's temporary migrants, non-citizens of where they live, yet permanent citizens of countries that don't have enough jobs to keep them at home. They are the Filipino women (Filipinas) who migrate to Hong Kong, Toronto and even Rome to become domestic workers while their brothers take work on the ships that carry the world's goods. They are the Bangladeshi women who are trafficked into brothels in India. They are the Mexican men who come to Ontario annually to work as farm labourers.

While the International Monetary Fund and the World Bank regulate the flow of international capital and the World Trade Organization governs the movement of goods across borders, no organization monitors the international flow of labour. If there were one, it would report a crazed pace of people flowing from developing nations to developed ones. It would tell the stories of the Central Americans who risk their lives time and again to smuggle their way through the Mexico-US border. It would adopt the heart-wrenching sight of Africans bobbing in the Mediterranean as its symbol of the lengths people will go to find greener pastures.

It might even resolve to tackle the root causes of this migration. As Dumagues and millions before her have found, developed countries are a gold mine. A few years of work abroad can yield the same savings as decades of work in their home countries and help to secure opportunities they previously only dreamed of. When Ivy Tamgga begins her new job as a front desk clerk at a hotel in Dubai, she'll be making seven times what she currently makes as a computer programmer in Manila. The idea flusters the 26-year- 
old. "It's not right that I will make more there, doing nothing, than working here and doing something important."

With remittances from abroad, a family in the Philippines can afford groceries and begin to meet their basic needs. This done, they often still have enough money to put their children into private schools and pay for university and college degrees. ${ }^{6}$

No country has seized on the opportunities offered by migration like the Philippines. "Migration is to the Philippines what cars once were to Detroit: its civil religion," writes Jason Deparle in the New York Times. "A million Overseas Filipino Workers -- O.F.W.'s -- left last year, enough to fill six $747 \mathrm{~s}$ a day. Nearly half the country's 10-to-12-year-olds say they have thought about where to go." ${ }^{\prime 7}$ More than 10 per cent of the country's population of 89 million live abroad, making the Philippines the top source of migrant workers in the world, followed by Sri Lanka, Bangladesh and Thailand. "It's an industry," says one Canadian government employee who monitors Filipino migration to Canada. He declined to be named. "The Filipino government sends these people out just to get their remittances. They have three government-sponsored agencies dedicated to placing Filipinos around the world." OFWs arrive on the doorsteps of some 170 countries to work both legally and illegally, as care-givers, general labourers, sex workers, teachers and nurses. They have become integral to countries in

\footnotetext{
${ }^{6}$ E. R. Rodriguez, "International migrants' remittances in the Philippines," The Canadian Journal of Economics / Revue Canadienne d'Economique, 29.2(1996): S427-S432.

${ }^{7} J a s o n$ Deparle, "A good provider is one who leaves," The New York Times 22 April 2007, 15 April 2008 $<$ http://query.nytimes.com/gst/fullpage.html?res=9D04E7D61 13FF931A15757C0A9619C8B63\&sec=\&sp on $=$ \&pagewanted $=2>$.

${ }^{8}$ Balangue 3.
} 
which they have no citizenship claims. ${ }^{9}$ As Nigel Harris writes in his book The New Untouchables, "Filipinas are everywhere, a genuine labour force - maids gossiping and smoking on their day off in downtown Hong Kong or Singapore, working in Japanese farms, running the duty-free shops of Bahrain, cleaning most of the world's cities from London to Sao Paulo." ${ }^{10}$ Filipino American academic E. San Juan likens the global marketing of Filipino labour to the trade of African slaves in previous centuries and writes that the migrant experience has become synonymous with the Filipino experience." "We are now a quasi-wandering people, pilgrims or prospectors staking our lives and futures all over the world - in the Middle East, Africa, Europe, North and South America, in Australia and all of Asia, in every nook and cranny of this seemingly godforsaken earth." ${ }^{12}$ The overwhelming desire by Filipinos to migrate for work, he adds, "determines our image, our identity and our notion of our future, to a larger degree than any ethnic particularism we can boast of."13

The OFW craze has spurred multiple industries in the Philippines; loans cater specifically to families with OFWs, hotels host Balikbayan only and a line of travel accessories, called Balikbayan Travel Gear, sells everything an OFW could need, from fanny packs to ropes and covers for Balikbayan boxes. Office buildings like the Midland Plaza in Manila have been transformed into OFW centres, with recruitment agencies,

9Pura Velasco, "Filipino Migrant Workers Amidst Globalization," Canadian Woman Studies (Spring/Summer 2002):132.

\footnotetext{
${ }^{10}$ Nigel Harris, The New Untouchables: Immigration and the New World Worker (London: B. Tauris and Company, 1995) 15.

${ }^{11}$ E. San Juan, Filipinos Everywhere: Displaced, Transported Overseas, Moving On in the Diaspora (Quezon City, Philippines: IBON Books, 2006) 109.

${ }^{12}$ Ibid., 74-75.

${ }^{13}$ Ibid., 157.
} 
travel agents and would-be OFWs crammed into every inch of the three-story complex. The walls are lined with job advertisements, all marked urgent, demanding everything from photographers to coffee makers and trailer drivers for countries ranging from Qatar to Australia.

As Rona Panizale, a Filipina bound for the Netherlands in a matter of months explains, "if you don't have relatives who live abroad, it's not normal." She learned what an OFW was 15 years ago, when she was eight years old. That was the word used to explain the big changes happening in her family; why they had to sell everything they owned so that her mother could move to Dubai to work as a domestic helper.

Her mother would visit every two or three years for one month, says Panizale, and the rest of the time she was raised by her grandparents. She missed her mother growing up, but says the sacrifice was worth it. "It's so hard here. Even if you have a good job, it's so hard to make money," the twenty-three year old says earnestly. "People in the Philippines, they live off loans. That's all." The family's gamble paid off and today the Panizales have paid off their loans, own an eight-bedroom mansion in a gated community and have access to anything they could ever ask for. It's all been made possible by their mother's 15 years of overseas work.

With remittances from their mother, the family was able to put all five of the Panizale children in the best private schools and pay for their college and university degrees. As they graduated university, one after the other, each found jobs in the Philippines. But the money was never enough to compete with what they knew they could earn abroad, the jobs never challenging enough to keep them satisfied. One by one, they went overseas. The first, Bibi, left seven years ago to become a nanny in the 
Netherlands. She now lives there with her Dutch husband and their child. Another sister went to visit Bibi in the Netherlands and never came back. She's now working illegally as a nanny, collecting as many Euros as she can before being deported to the Philippines. Panizale's sister-in-law has just finished her paperwork to go to the Netherlands as a nanny and is planning on leaving in a few weeks. Rona, the youngest of the siblings, is hoping to leave for the Netherlands in a few months, pending the last bits of paperwork. She'll be an au pair to a 12-year-old, she's found out. "It's a start," she explains. "Once I'm there I can choose if I want to be a nanny or try to use my college degree in commerce."

The family has one sister left in the Philippines. She takes care of all the children left behind - three of them, plus one of her own. She and her husband tried long ago to migrate to Canada, she says, but their application was denied. Now she's accepted that her job is to stay in the Philippines and play caregiver to the Filipino quotient of the Panizale family.

With so many OFWs to keep the family afloat, the Panizales have been asking their mother to retire and come home. She's been ill for sometime, Panizale says, "but she thinks she will get better medical care in Dubai." She also loves her life there and doesn't want to come home, admits Panizale. She works for a nice family and would rather stay there than come home and live with the family she barely knows anymore. Her decision has left Panizale's aging father to live out his days alone, watching TV and hoping that his wife will change her mind.

During family gatherings, the absent ones are present only in the photographs and gifts they send. At a $13^{\text {th }}$ birthday party for Panizale's nephew - one that his mother 
missed because she was working illegally in the Netherlands - the latest pictures of the family members overseas are passed around. Everyone exclaims how much fun the smiling women look like they're having away from home. Bottles of French wine are opened and Dutch chocolates are offered to guests.

It's just how life here is, says Panizale. When she was growing up, most of the kids at her private school were just like her, with one parent working overseas to finance their education. "It's really normal," she says flippantly, "its okay."

As for her, she's nervous and excited about moving to the Netherlands. "My friends, I'll miss them. My family too - but not the country," she says. "I want to live in Holland. And come back to the Philippines only for visits."

An estimated one million migrant workers from the Philippines live in Saudi Arabia alone. Japan, Hong Kong, the United Arab Emirates and Taiwan follow closely behind as main destinations for Filipinos seeking overseas work. The men dominate international waters, making up one-quarter of the world's seafarers.

Once abroad, what they send home is jaw-dropping. The Philippines received US $\$ 15$ billion in formal remittances in 2006, exceeded only in real numbers by India (US\$25 billion), China (US\$24 billion) and Mexico (US\$24 billion). Remittances account for 14 percent of the Philippines' GDP in 2006 and represented the country's single biggest source of foreign exchange. ${ }^{14}$ It takes a stroll through any Filipino neighbourhood to see remittances at work, says foreign aid worker Alice Rotan. "Mansions sit next to huts," she explains, "and all of the nice houses are because someone is overseas, sending back money."

\footnotetext{
${ }^{14}$ Balangue 3.
} 
The numbers have taken the development community by storm and provoked questioning as to whether remittances are the solution to global poverty. In the eyes of these theorists, global capitalism sustains an overarching system that organizes nations based on unequal relationships. Migrants are an inevitable outcome and in high demand, simply reflecting the continuous circulation of resources - both capital and labour - that takes place between a dominant core and dependent peripheral nations. ${ }^{15}$ As migrants, the theories say, their lives are not defined by the free will often ascribed to individuals, but rather by situations and statuses conferred upon them. ${ }^{16}$

The excitement over the development potential of migration competes with a body of literature that documents the social consequences of this development strategy. Interviews with domestic workers in Rome and Los Angeles speak of the children they left behind, elders in the Philippines lament at how everyone in the country has their sights set abroad and instead of recounting what they want to be when they grow up, high school students in the Philippines detail where they want to be.

Others have argued that remittances essentially punish the poor by making migrants pay obscene costs, such as family separation, contradictory class mobility and social exclusion, in order to enact their own development. Critics have pointed to the ambiguous citizenship that migration bestows on Filipinos. "Neither fully integrated in receiving nations nor completely protected by the Philippines, they are at most only

\footnotetext{
${ }^{15}$ Kathie Friedman-Kasaba, Memories of Migration: Gender, Ethnicity and Work in the Lives of Jewish and Italian Women in New York, 1870-1924 (Albany, NY: SUNY Press, 1996).

${ }^{16}$ Joan Scott, "Experience," Feminists Theorize the Political, eds. Judith Butler and Joan W. Scott, 34 (New York: Routledge, 1992).
} 
partial citizens," writes Rhacel Salazar Parrenas in her exploration of the lives of domestic helpers in Los Angeles and Rome. ${ }^{17}$

But it's hard to argue with economics. Persistent neo-liberal restructuring of the Filipino economy has lead to massive unemployment and underemployment in the Philippines, creating a migrant workforce that Canadian sociologists Daiva Stasiulis and Abigail Bakan call the "underbelly of globalization." ${ }^{.18}$ As Filipina Pura Velasco, a former domestic worker in Canada, writes, "The impact of globalization on the lives of poor Filipinos is so devastating, and the need for jobs so pressing, that despite the horrifying stories of injustices suffered by Filipino migrant victims, Filipino workers cannot be dissuaded from leaving the country." 19 Her words are confirmed by actions; from the Filipinos who travel to far-flung destinations like Papua, New Guinea, Angola and Afghanistan for work, to the Filipino migrants who hid when their government tried to evacuate them from Iraq after a Filipino truck driver was kidnapped in 2004. Many protested the government's ensuing attempts to ban migration to Iraq, arguing that they "would rather go to Iraq to work and be killed instantly rather than die a slow death in their beloved Philippines. ${ }^{20}$

The culture of migration is not discouraged by the three to four OFW corpses that arrive daily at the Manila International Airport. They're not seen as victims of poor employment conditions or mental stresses that forced them to claim their own lives, but

\footnotetext{
${ }^{17}$ Rhacel Salazar Parrenas, Servants of Globalization: Women, Migration and Domestic Work (Stanford: Stanford University Press, 2001) 37.

${ }^{18}$ Daiva Stasiulis and Abigail B. Bakan, "Negotiating Citizenship: The case of foreign domestic workers in Canada," Feminist Review 57(Autumn 1997): 121.

${ }^{19}$ Velasco, Filipina Workers 132.

${ }^{20}$ San Juan, ix.
} 
lauded as Balikbayan of the truest form; even dead, Filipinos always return home. ${ }^{21}$ "They say that most Filipinos go by suicide," admits Panizale of the returning bodies. "But I think it's not true - Filipinos are so strong. They can take lots." David Wurfel, professor emeritus of Filipino politics at the University of Windsor, has watched migration slowly become a staple in the Philippines over the past three decades. "Their blindness to the downside of going abroad is really amazing," he says, adding that it is partly "because the people who come back want to talk about the glories of their overseas experience rather than the trials and tribulations."

In the early 1900s, the Philippines exported their men to work in the sugar plantations of Hawaii, a migration that was soon curtailed by a US national-origin quota system that limited Filipino migrants to 100 in the next decade. ${ }^{22}$ But the foundation for migration as a civil religion was to come decades later, in the 1970s under the reign of Filipino president Ferdinand Marcos. With his narrow hold on power compromised by soaring unemployment, communist rebels and growing unrest among Filipinos, the export of labour held particular potential to stabilize the unstable economy. Marcos issued a 1974 degree to "facilitate and regulate the movement of workers," introducing labour exports as a permanent fixture in Filipino politics and unleashing the talents of Filipinos on the globe. Marcos himself lobbied the Middle East, other Asian countries, Europe, the United States and Canada to import Filipinos. ${ }^{23}$ While fewer than 50,000

\footnotetext{
${ }^{21}$ Ibid., vi.

${ }^{22}$ Ibid., 19.

${ }^{23}$ Linda Basch, Nina Glick-Schiller and Christina Szanton Blanc, Nations Unbound: Transnational Projects, Postcolonial Predicaments and Deterritorialized Nation-States (Langhorne, PA: Gordon and Breach Science, 1994).
} 
Filipinos left in the mid-1970s, more than 250,000 left in $1981 .{ }^{24}$ By the time Marcos was deposed in 1986, the export of labour was so deeply engrained in the economic infrastructure of the Philippines that it was barely questioned by his successors. By 1994 , the surge of labour migrants had reached $700,000{ }^{25}$ The Filipino economy quickly became dependent on the export of workers to ease high unemployment and underemployment rates, provide workers with additional skills training and generate foreign currency from the remittances of overseas workers. ${ }^{26}$ Without labour migration, it's estimated that the rate of unemployment in the Philippines would increase by 40 per cent. $^{27}$

Today the issue in the Philippines is not whether Filipinos should be leaving, but how to best protect migrants who are abroad. The definitive moment of this shift in thinking came with the execution of Flor Contemplacion, a domestic worker employed in Singapore who was accused of murdering another Filipina maid there.

In 1991, Delia Maga was found strangled to death. The four-year-old she was looking after, Nicolas Huang, was also found dead in the bathtub. Nicolas' father could not name a suspect and Contemplacion was identified to police through Maga's diary. During police interrogation, Contemplacion admitted to killing both Maga and Huang,

\footnotetext{
${ }^{24}$ Philip Martin, "Migration and Trade: The Case of the Philippines," International Migration Review 27.3 (1993): 639-45.

${ }^{25}$ Ibid., 639-45.

${ }^{26}$ Manolo Abella, "International Migration and Development" Philippine Labour Migration, eds. Graziano Battistella and Anthony Paganoni (Quezon City, Philippines: Scalabrini Migration Centre, 1992) 22-40.

${ }^{27}$ Stephen Castles and Mark J. Miller, The Age of Migration: International Population Movements in the Modern World, $2^{\text {nd }}$ ed. (New York: Guilford Press, 1998).
} 
though she did so in an uncertain mental state and with weak legal representation. She was sentenced to death by hanging.

Prior to her execution, two Filipina witnesses fingered Nicolas' father for the murders. They claimed that Nicolas was an epileptic who had drowned by accident in the bathtub and that his father had murdered Maga in rage and then framed Contemplacion for the murders. Their testimony was considered and rejected by a Singapore court. Contemplacion was then executed, despite Filipino President Fidel Ramos' $11^{\text {th }}$ hour bid to stay the execution.

The outcry in the Philippines - and in the Filipino Diaspora - was tremendous. Contemplacion became a martyr to Filipinos, who believed she was innocent or, if she had committed the murders, had done it out of temporary insanity brought on by the mental stress of domestic work. President Ramos' wife, Amelita Martinez, received her coffin at the Manila airport while the president himself sent a wreath to her funeral and offered financial assistance to Contemplacion's children, who were dependent on her income as a domestic worker abroad to meet their basic needs. The Catholic Church, which continues to wield considerable influence in this country where more than threequarters of the population is Roman Catholic, condemned the execution. ${ }^{28}$ A communist terrorist group in the Philippines, the Alex Boncayao Brigade, threatened to punish Singaporean and Filipino officials. Filipinos accused the Singapore government of not being merciful enough and their government of not doing enough to stop the execution. In response, President Ramos removed the Filipino ambassador to Singapore and cancelled most bilateral trade with Singapore.

\footnotetext{
28“"The Philippines" The World Factbook, Central Intelligence Agency, 15 April 2008 $<$ www.cia.gov/library/publications/the-world-factbook/geos/rp.html>
} 
Others used her case to vent their frustrations at their own government and the Singaporean government over the inhumane, abusive and exploitative working conditions faced by migrant workers from the Philippines. A movie called The Flor Contemplacion Story was made, telling her story and highlighting the mental stresses, helplessness and vulnerability facing migrant workers. The movie went on to win best picture at the Cairo Film Festival, spur a much-needed dialogue regarding the rights of international migrants and embed this dialogue forever in Filipino culture.

It became institutionalized in the Philippines with the passing of Republic Act 8042, known as the "migrant workers' Magna Carta." 29 The act pushed the government of the Philippines to invest as much effort in protecting migrants as they were putting into placing migrants abroad.

Rather than risk the wrath of Filipinos, current President Gloria MacapagalArroyo has worked hard to uphold Republic Act 8042. As mentioned earlier, the 2004 kidnapping of a Filipino truck driver in Iraq resulted in a ban of Filipino placements in Iraq along with withdrawal from the American-led military coalition. Lobbying proved successful in convincing King Abdullah of Saudi Arabia to free more than 400 Filipino workers who had been jailed for petty crimes. Arroyo's government has imposed an indefinite ban on the deployment of new workers to Jordan after an estimated 150 of them, mostly domestic helpers, sought refuge at a Philippine-run centre in Amman due to maltreatment, rape and non-payment of wages. But the government can only do so much, as evidenced by the disturbing tales of abuse that migrant workers continue to bring home with them. When the bombings began in Lebanon in 2006, many Lebanese

\footnotetext{
${ }^{29}$ Deparle, 4.
} 
fled, leaving their Filipina maids locked in their apartments with hopes that they would look after the place while their employers were gone. With bombs exploding around them, many of the maids tied the drapes together to fashion an escape. For some it worked, but dozens of others fell to their deaths. Thousands more Filipina maids were displaced during the war, as Deparle writes, returning "home with harrowing tales of prewar abuse, including beatings and rape, endured in pursuit of salaries that averaged US\$200 a month. ${ }^{\circ 30}$

In response, the government sought to increase the value of Filipina domestic workers abroad by imposing a "Supermaid" program, a short-term training program designed to lift their skills and allow them to demand a doubling of their wages. Critics worried that if Filipina maids demanded pay raises and better working conditions, their employers would replace them with their Bangladeshi and Indonesian counterparts.

In the Philippines, going abroad depends on your financial resources. Panizale says the USA is the most sought-after destination, followed by Canada, Australia, Europe, the Middle East and, lastly, Asia. The rankings reflect the salary to be earned and potential for obtaining citizenship in each country.

The fees recruitment agencies charge workers vary widely, depending on the placement country, and reflect these preferences. The cost is determined by the prospective wages of the workers and also by the distance between the receiving country and the Philippines. For example, agencies in the Philippines charge approximately US $\$ 600$ to place a domestic helper in Hong Kong, where the monthly salary, stipulated by contract, is about US\$475. Singapore is another low-cost destination, stemming from

\footnotetext{
${ }^{30}$ Ibid.
} 
the fact that the average monthly pay hovers around US\$200..$^{31}$ Many agencies offer programs to foot the bill to place domestic helpers in Singapore, in exchange for the first year of wages. In contrast, to be placed in Italy can cost up to US\$5,000, but those who make it can expect to earn up to US $\$ 1,229$ per month. ${ }^{32,33}$ Part of this cost reflects the risks inherent with migrating to Italy, as agencies catering to prospective migrants are not state-sanctioned, as is the case in Hong Kong, but illegal operations that facilitate undocumented migration. ${ }^{34}$ Migration to Canada - where permanent citizenship is up for grabs-- can run as high as US\$8,300 while entry into the United States remains an elusive goal. There they enter with a temporary non-migrant visa, often only granted to those who can prove economic security through documentation of property, investment and savings in the Philippines. ${ }^{35}$

The fees restrict who can become an OFW, favoring the Filipino middle-class, or those who already have family and friends overseas willing to contribute to the fees. What results is a development strategy that, for the most part, benefits the middle-class rather than the poorest of Filipino society. OFWs separate the Philippines into two distinct classes, explains Jessie Gasner, an American aid worker based in the Philippines from 2001 to 2003 . "There are the regular Filipinos and then there are the ones with OFWs who are like middle-class Americans - nice house, nice car and lots of money."

\footnotetext{
${ }^{31}$ Brenda S. A. Yeoh, Shirlena Huang and Joaquin Gonzalez III, "Migrant Female Domestic Workers: Debating the Economic, Social and Political Impacts in Singapore," International Migration Review 33.1(1999).

${ }^{32}$ Parrenas, Servants of Globalization 19.

${ }^{33}$ Ibid., 40.

${ }^{34}$ Ibid.

${ }^{35}$ Ibid.
} 
Material possessions aside, critics have questioned whether the country is actually benefiting from migration. Some claim that the remittances the OFWs send home have led to a dependency on outside sources for income, rather than stimulated economic growth in the Philippines. ${ }^{36}$ Others argue that having every pair of eyes cast outside the country has allowed corruption to become rampant within the current administration and the foreign debt of the Philippines to balloon to US\$35 billion, depleting any of the economic gains made by migration. ${ }^{37}$

These criticisms have been accompanied by an exploration of the personal costs Filipinos bear in order to migrate. The OFW predicament is captured powerfully by Angelo de la Cruz's response after he was released by his kidnappers in Iraq in 2004. "They kept saying I was a hero...a symbol of the Philippines. To this day I keep wondering what it is I have become. ${ }^{38}$ San Juan pushes his question further, asking "how did Filipinas/os come to find themselves scattered to the four corners of the earth and subjugated to the position of selling their selfhoods?"39

\footnotetext{
${ }^{36}$ Manolo, 22-40.

${ }^{37}$ Ninotchka Rosca, “The Philippines' Shameful Export," Nation, 260.15(1995): 526.

${ }^{38}$ San Juan xiii.

${ }^{39}$ Ibid., 109-110.
} 


\section{Chapter 1: Life Abroad}

Cathy Devera can't decide whether to be nervous, terrified or excited. In just one week, she will leave her home in Manila, take her first-ever airplane trip and arrive in Vancouver, Canada to work as a domestic helper. She's got the work visa. She's got the plane ticket. She's got the names of distant relatives in Vancouver who have promised to help her ease into her new home.

She's already spoken to them once; they told her that Canada is cold in February and warned her to bring sweaters. They assured her, she says, that "Canadians are like Filipinos - very nice." They told her that the work is hard, saving money is harder but that it can be done.

And it will have to be done. What's driving 30-year-old Devera to travel thousands of kilometers across the world for work are her five children, who range in age from three to 12 years old. "I need to do this for my kids," she says emphatically. "They need to go to college, they are so smart. My oldest, she wins so many awards at school."

She's taken the last month off from her job as a marketing assistant for a medical company to spend time with her children, who she will be leaving in care of her parents. She's especially worried about her youngest. "I'm going to miss him so much," she says, tears welling in her eyes. "But it's okay," she reassures herself. It's just part of life, she says, more to herself than anyone else. "Ba hala na," she adds in Tagalog, a favorite saying of Filipinos, whose meaning lie somewhere between "God will provide" and "come what may."

Whenever she gets upset about leaving, she cheers herself up by thinking of all the things that her family will be able to afford with her remittances. A family vacation 
to Boracay, the Philippines' premier beach. A big house that can replace the small, dilapidated two-bedroom home where she and nine others in her family live. A chance to become a Canadian citizen and sponsor her family to become Canadians as well.

It took one year and cost her thousands of US dollars to apply for overseas jobs fees her family paid through a combination of savings and loans from relatives abroad. She was offered jobs Dubai and Canada, but chose Canada because she's hoping to eventually gain citizenship there. Also, she adds, the money is much better.

The mood at her house on the outskirts of Manila is sombre. Her husband, Nestor Pulin, who works as a maintenance man for Manila's public transit system, has no idea what he'll do without his Cathy. Her oldest daughter says it will be okay, as her mom will come back to visit as often as she can. Devera's parents are excited to join the ranks of OFW families in the Philippines and entranced with the possibilities of being able to afford anything they can dream of. "Cathy's always wanted to travel, now here's her chance," says her mother.

In the kitchen sits the family's lone suitcase, packed with everything Devera thinks she might need. Sitting on top is a thin, black cardigan - Devera's sweater for the Canadian winter.

The fate of migrants abroad varies greatly according to their destination. Some countries, such as Singapore prohibit migrant Filipinas from marrying or living with Singapore citizens, while being pregnant is forbidden to domestic workers in the Middle East and Asia. ${ }^{40,41}$ Filipinos maintain that Singapore is the worst place to go, insisting

\footnotetext{
${ }^{40}$ Abigail Bakan, and Daiva Stasiulis, "Introduction" Not One of the Family, eds. A. Bakan and D. Stasiulis (Toronto: University of Toronto Press, 1997).
} 
that many employers there treat their domestic help like animals, feeding them only leftovers and not allowing them time off. But, in droves, Filipinos continue to try their luck in Singapore, hoping to land a nice employer.

Migrant workers are eligible to apply for citizenship in a few countries, including Canada, Spain, the United States and Australia. In Canada and Spain, domestic workers are eligible to apply for full citizenship after two years in the country. ${ }^{42}$ Italy, one of the most popular destinations for Filipinas, allows migrant workers to stay up to seven years and while they are restricted to domestic work, they are not contractually tied to one employer. Since the 1990 s, temporary residents can sponsor their families to join them in Italy.

Peter Matheson, originally from Scotland, worked for 20 years supervising construction sites in Saudi Arabia. The majority of workers at his sites were from the Philippines. "They worked hard," he recalls, "but whenever you got a new batch, you would have a few who didn't even know how to hit a nail. You would know that they just got there because they paid someone to give them a visa. But their friends would cover for them and teach them and in no time they would be fine."

Matheson, now retired, remembers the Filipino workers fondly. On a recent trip to Saudi Arabia, he met a young Filipino man working in construction and was shocked at the stories he heard about life on the site. "When I worked there, they were allowed to go home once a year, but now its every two years. That's unbelievable - they're just exploiting these people," he fumes. "And you know what's the worst of it? These people,

\footnotetext{
${ }^{41}$ Pei-Chia Lan, "Bounded Commodity in a Global Market: Migrant Workers in Taiwan," Paper presented as the 1999 Annual Meeting of the Society for the Study of Social Problems, Chicago, 6-8 Aug. 1999.

${ }^{42}$ Parrenas, Mothering from a Distance 50.
} 
they think they're lucky to have a job. They're thanking us all the time for letting them work."

That's one of the reasons Canada favours Filipino migrants, says one Canadian working at the embassy in the Philippines. "They're young, they want to go abroad and they're ready to make some money," he says, declining to be named. "The Philippines is by and large the best place to recruit people - they speak English and they've got a good work ethic."

The feeling is mutual, as Canada is one of the most sought-after destinations for migrant workers from the Philippines. "Going to Canada is my dream," one cab driver confides, "but I have no more than a grade three education." Another family tried unsuccessfully for years to land a job in Canada. "They told me that I need to volunteer more," the father grimly explains. "I want to come to Canada and drive a bus," says one bus driver excitedly, "you need bus drivers there, right?"

Their enthusiasm for Canada is echoed around the world. When it comes to life expectancy, opportunities for education and access to material resources, the United Nations Human Development Index consistently ranks Canada as one of the "best countries in the world to live."43 It's this, safe, multicultural Canada with plenty of opportunities for everyone that consistently lures Filipinos like Devera to work in lowskill jobs.

But the Canadian dream is much different from the reality. The majority of the OFWs arrive in Canada through the Live-In Caregiver Program (LCP), the moniker given to Canada's recruitment program for domestic workers. "Last year 6,541 LCP work

\footnotetext{
${ }^{43}$ Human Development Reports, United Nations Development Programme, 26 Oct. 2007 $<$ http://hdr.undp.org/reports/global/2001/en/clips/>
} 
permits were approved - 5,956 of those were from the Philippines. Those are some pretty powerful numbers," says Danielle Norris, a spokesperson for Citizenship and Immigration Canada.

Some of those who arrive, like Joy Madulid, are fortunate. She came to Canada from the Philippines through the LCP in 2002, when she was just 23 years old. "I felt that I needed to grow and I could see some great opportunities out there to learn something new," she says. Moving across the world for a job was a big change for this shy, quiet woman. But a few years --and Canadian citizenship-- later, Madulid remembers the LCP fondly. "I was treated very well as a caregiver. As a matter of fact they treated me as a part of their family and I felt like I was at home." After a pause, she adds, "The live-in caregiver program is a great program for people who would like to work and live permanently here in Canada."

She knows her rave reviews of the program are not shared by everyone. "I consider myself as an exception," she says, "because many of my friends encountered employers where they were not treated very well."

For some domestic workers, life in Canada consists of being overworked, underpaid, sexually harassed and unjustly deported at the will of immigration officers. ${ }^{44}$ Pura Velasco, once a domestic worker from the Philippines and now a Canadian citizen writes, "As a domestic under the [Live-In Caregiver Program], I felt like a prisoner serving time for Immigration Canada and for my employers for almost three years. And

\footnotetext{
"44 Judith Ramirez, "Indentured Servitude," rev. of Home Economics: Nationalism and the making of "Migrant Workers, by Nandita Sharma, Literary Review of Canada_ 14.2 (2006): 14.
} 
what was my crime? I was poor." ${ }^{45}$ Her words echo those of Kelly Botengan, a former domestic worker and spokesperson for the Canadian domestic worker advocacy group, the Philippine Women Centre. "The Philippine government can no longer deny that the LCP continues to claim and destroy the lives of countless Filipinos who dream of creating a better life for themselves and their families back home," says Botengan. ${ }^{46}$

"It's a very complex program," says Regina Sosing Ferrar, a Filipina who arrived in Canada through the LCP more than 15 years ago. "There are problems with the program and that is for sure. But I would be very, very sad if it were taken away."

History reveals that these shortcomings are not personal but instead inextricably tied to the racialized and sexualized history of the temporary worker program. Canada began importing foreign domestic workers prior to the Second World War. Aside from a short lived experiment in 1911, where 100 domestic workers from Guadeloupe were recruited, most domestic workers in Canada during this period were from Europe. Many of them were British and Scottish women who arrived in Canada as permanent settlers, but were first required to perform domestic service for six months. ${ }^{47}$ Changes to the domestic workers program in 1955 brought women from the Caribbean, primarily Jamaica and Barbados, along with women from Eastern Europe who had been displaced by war. The shift from Europeans to women from the Global South was partnered with more restrictions and an extension of the period of bonded service to one year. The

\footnotetext{
${ }^{45}$ Pura M. Velasco, "We can still fight back," Not One of the Family: Foreign Domestic Workers in Canada (Toronto: University of Toronto Press, 1997) 160.

${ }^{46}$ Aubrey Makilan, "Filipina caregiver in Canada killed, another dream ending in tragedy," Bulatlat 7-13 Oct. 2007, 01 Dec. $2007<\mathrm{http} / /$ www.bulatlat.com/2007/10/filipina-caregiver-canada-killed-anotherdream-ending-tragedy>

${ }^{47}$ The Philippines-Canada Human Resource Development Program, Uneven Gains. (Ottawa: North-South Institute, 1996) 19.
} 
program was limited to single, healthy women within the age of 18 to 40 years. Testing for venereal disease was mandatory and based on the premise that women from the Caribbean were sexually promiscuous. ${ }^{48}$ It was hoped that through the recruitment of single women, the entry of any dependants from the Caribbean into Canada would be discouraged. ${ }^{49}$ The practice of allowing domestic workers to enter Canada as permanent settlers was ended by the Canadian government in 1973. Instead, employment visas issued under the Employment Authorization Program specified that domestic workers were only able to stay for a specific duration, usually a year, and termination of domestic servitude meant leaving the country. In 1981, intense lobbying by domestic worker advocacy groups resulted in the opportunity to apply for landed immigrant status under the Foreign Domestic Movement Program, now known as the LCP. ${ }^{50}$

The demand for domestic workers soared as middle-class, Canadian women stayed in the work force after they married and had children. Ironically, as they secured modest gains in equality of opportunities, and helped provide financially for their families, the doors opened for more migrant women from the Global South to come to Canada and live lives characterized by a lack of opportunity in Canadian terms. From 1975 to 1993 , Canadian women's participation in the labour force rose by 71 per cent. ${ }^{51}$ These gains in equality in the workforce were compromised by a lack of gains in obtaining institutionalized child care. A 1992 study found that 2.9 million children in

\footnotetext{
${ }^{48}$ Agnes Calliste, "Canada's Immigration Policy and Domestics from the Caribbean: The Second Domestic Scheme. Race, Class, Gender: Bonds and Barriers" Socialist Studies/Etudes Socialistes Nov. 51989.

${ }^{49}$ The Philippines-Canada Human Resource Development Program, 19.

${ }^{50}$ Ibid.

${ }^{51}$ Status of Women Canada. Canada's National Report to the United Nations for the Fourth World Conference on Women. (Ottawa: Status of Women Canada, September 1995).
} 
Canada lacked access to regulated care and were instead being cared for by relatives, nannies and baby-sitters. ${ }^{52}$

Enter the LCP. Federally, the importing of highly-educated women from developing countries to work as live-in nannies provides a cheap alternative to a universal child-care system. ${ }^{53}$ On the ground, the hiring of a live-in domestic worker is an attractive alternative for dual-income families with young children, as it is often more cost-effective than hiring live-out nannies, whose room and board cannot be deducted from their paycheque, or paying for day care, which can cost as much as $\$ 1,200$ per child per month. ${ }^{54}$ Live-in domestic workers also come with the added benefit of performing household work other than child care.

The LCP, as it became known in 1992, markets itself as program that enables individuals from the Global South to come to Canada and care for children, elderly persons or persons with disabilities in private homes. ${ }^{55}$ Both men and women can apply to the program, but men are very rarely accepted. The LCP lures workers with the promise that those who complete two years of the program can apply for landed immigrant status and potentially obtain Canadian citizenship. ${ }^{56}$ Application to the LCP is limited to those with Grade 12 education, who are fluent in English or French and have at least 12 months of domestic work experience. Prior to applying to the LCP, potential

\footnotetext{
${ }^{52}$ Ibid.

53،Canada: The new frontier for Filipino Mail-Order Brides" Status of Women Canada 29 Oct. 2003,01 Dec. 2007 <http://www.swc-cfc.gc.ca/pubs/pubspr/0662653343/200011_0662653343_9_e.html>

${ }^{54}$ The Philippines-Canada Human Resource Development Program, 18.

${ }^{55}$ Working temporarily in Canada: The Live-In Caregiver Program" Citizenship and Immigration Canada 31 March 2007, 26 Oct. $2007<$ http://www.cic.gc.ca/English/work/caregiver/index.asp>

${ }^{56}$ Ibid.
} 
workers must first have an employment authorization that specifies who they will be working for and their conditions of work, a step that often requires a placement agency. If their application is successful, they enter Canada as temporary workers and are subject to provincial labour laws. Those who work in Ontario are guaranteed wages of $\$ 9.25$ per hour for a work week that ranges between 30 to 48 hours. $^{57}$ They are required to live in the residence of their employers. Disability benefits are optional for employers and domestic workers are not entitled to sick leave. Once in Canada, they must work for the employer listed on their work permit and need written permission from an immigration officer to change jobs. If they leave their jobs without permission, they will be immediately deported. ${ }^{58}$ Before landed immigrant status can be obtained several criteria have to be met, including completion of two years of "satisfactory" live-in domestic service, proficiency in either English or French, upgrading of skills that would facilitate integration into the Canadian labour force, performance of volunteer work in the community to show social adaptation and personal suitability, sound financial management with savings and receipts of remittances as proof of their ability to support dependents. $^{59}$

The number of people from the Global South, predominantly women, who participate in the LCP continues to rise. Government data show that between 2001 and 2004, the number of foreign domestic workers in Canada nearly doubled, from 10,531 to

\footnotetext{
57"Live-in Caregiver. Ontario Prevailing Wage Rates and Room and Board Rates, effective February 1, 2007." Ontario Provincial Government 15 Feb. 2007, 26 Oct. 2007

$<$ http://wwwl.servicecanada.gc.ca/en/on/epb/fwp/lic.shtml>

${ }^{58}$ Ramirez, 14.

${ }^{59}$ Rita Parikh, "I Could Put This House on Fire: The Everyday Resistance of Filipina Domestics in Canada," M.A. Thesis, Norman Paterson School of International Affairs, 1994, 55.
} 
$19,820 .^{60}$ The majority of these are Filipinas, for whom traversing borders to take care of a stranger's family is often their best hope of caring for their own family. They are, as Parrenas calls them, the "servants of globalization," a cheap, docile labour force of mostly women, unleashed on the world as a result of a lack of opportunities in the Philippines. ${ }^{61,62,}$ For Ferrar, the LCP offered her an escape from her village where there was no electricity and no running water. "If I were in the Philippines, I wouldn't have the chance to experience what I have over the past years. It's a give and take situation." Today Ferrar is a Canadian citizen, is married to a wealthy Canadian and has two beautiful sons. "There are good things that happen to people that make it through the program," she insists. Ferrar's three sisters all came to Canada through the LCP, allowing them to send back large remittances to the Philippines. "My family is way better now than before we had anyone abroad," she says. "It's really sad that we had to leave to do that."

Approximately two-thirds of workers who arrive in Canada through the LCP settle in Ontario, particularly in metro Toronto. ${ }^{63}$ Filipinas are now favoured as domestic workers, partly due to stereotypes perpetuated by placement agencies that depict Filipinas as subservient, hard-working and loving caregivers to young children. ${ }^{64}$ Interestingly, many Filipinas who come to Canada to work as domestic workers learn these 'inherent'

\footnotetext{
${ }^{60}$ Ramirez, 15.

${ }^{61}$ Parrenas, Servants of Globalization title page.

${ }^{62}$ Velasco, Filipina Workers 132.

${ }^{63}$ The Philippines-Canada Human Resource Development Program, 21.

${ }^{64}$ Abigail B. Bakan and Daiva Stasiulis, "Making the match: Domestic Placement Agencies and the Racialization of Women's Household Work" Journal of Women in Culture and Society, 20.21(1995): 308.
} 
nurturing and household skills on the job. ${ }^{65}$ Madulid had no experience in looking after children when she arrived in Canada, but was placed in a family with three children between the ages of two and 10 years. "It made being a caregiver a challenging job," she says, laughing. A wide variety of nanny schools in the Philippines, with names like the Fil-Canadian School of Training and Development for Caregivers, also teach these skills; earning their participants a certificate that is equivalent to the 12 months of domestic work experience needed for the LCP. Domestic workers from the Philippines have replaced those from the Caribbean, once a staple of the LCP but now less in favour after their repeated attempts to lobby for better citizenship rights for domestic workers in Canada. ${ }^{66}$

While Canada as a developed nation carries within it the assumption that the rights of women, workers and marginalized populations will be protected, race, space and the law combine to create unsafe working environments for Filipina domestic workers. Dozens of countries around the world host programs similar to the LCP, but Canada continues to draw Filipina caregivers, thanks to its reputation for tolerance and kind people. ${ }^{67}$ Inherent within the LCP promotional material is the promise that the rights of workers will be upheld. Prior to granting permission for a worker to become part of the LCP, Human Resources and Social Development Canada reviews the contract outlining job duties, working conditions and suggested pay to ensure that the job offer meets provincial labour standards and is "equivalent to those wages paid to Canadians in the

\footnotetext{
${ }^{65}$ The Philippines-Canada Human Resource Development Program, 21.

${ }^{66}$ Stasiulis and Bakan, Negotiating Citizenship 123.

${ }^{67}$ Sherene H. Razack, "Introduction" Race, Space and the Law: Unmapping a White Settler Society., ed. Sherene Razack (Toronto: Between the Lines, 2005) 4.
} 
same occupation." ${ }^{\prime 68}$ Other LCP material states clearly that domestic workers have "legal rights to fair working conditions and fair treatment under labour laws...nothing in your contract must violate these laws. ${ }^{299}$ Norris insists that what the government does is more than enough. "These live-in caregivers are also informed prior to coming to Canada about their recourse should they come in contact with some form of abuse or what they think is abuse," she says. "There are forms on the Internet, there are pamphlets given out to them prior to them coming, we talk to them face to face," she says. Yet once the contract is approved and the domestic workers arrive in Canada and begin work, there is no regulating body to ensure that these conditions are actually being met.

What can result is an exploitative workplace that is abusive towards these women. The LCP's requirement that domestic workers live with their employer places these workers in a particularly vulnerable position, as the private nature of their workplace conceals practices that would not be acceptable in other work environments. Failure to obey the live-in requirement results in deportation. ${ }^{70}$ Velasco writes that domestic workers routinely suffer sexual harassment, violation of employment contracts and other forms of abuse, often silently out of a fear of jeopardizing their immigration status. ${ }^{71}$ While Ferrar says that all three families she served in the LCP treated her adequately, she admits that she had to coach herself through it. "You know what I would say to myself? There's no turning back. I have to make this work. Going back to the Philippines is not

\footnotetext{
68،"The Live-In Caregiver Program: How to Apply" Citizenship and Immigration Canada 31 Mar. 2007, 01 Dec. $2007<$ http://www.cic.gc.ca/english/work/caregiver/apply-how.asp>

${ }^{69}$ "Frequently asked questions: Working temporarily in Canada" Citizenship and Immigration Canada 31 Mar. 2007, 01 Dec. $2007<$ http://www.cic.gc.ca/english/information/faq/work/caregiver-faq01.asp>

${ }^{70}$ Ramirez, 15 .

${ }^{71}$ Velasco, Filipino Workers 136.
} 
an option." As two years of "satisfactory" live-in domestic service is critical to obtaining landed immigrant status, women are reluctant to push for better working conditions or report abusive employer practices. A bad reference could put future work opportunities in peril, while dismissal could lead to deportation if they are unable to find a new employer before their work permits expire.

The LCP requires domestic workers to have "flexible" working hours to meet their employer's lifestyles and needs, meaning that they can be called upon at any time of the day to do any type of chore. The blurring of this line between work and off-duty hours results in domestic workers being awakened to put children to sleep in the middle of night, walking pets first thing in the morning, shovelling snow, painting walls and entertaining guests at midnight. ${ }^{72}$ They often don't receive compensation for these long hours. A 1992 survey of 592 domestic workers in Toronto found that 65 per cent were routinely required to work overtime and 45 per cent of them did not receive any compensation. ${ }^{73}$ Part of the problem lay in the employers' definition of real work. Some of them discount the hours their caregivers were forced to spend working in their businesses, waiting for them to come home at night or playing with children. The survey also found that only 34 per cent of women who were paid for overtime felt they were actually paid what they were owed. The rest complained that they were not paid legal rates of overtime or were not compensated for all of the hours they worked. Ferrar argues that this is just part of the job. "We have to be kind because this is family," she

\footnotetext{
${ }^{72}$ The Philippines-Canada Human Resource Development Program, 24.

${ }^{73}$ Ibid.
} 
says. "We can't be counting minutes and seconds. There is lots of give and take in the lives of caregivers."

While the provincial governments set the maximum amounts that can be deducted from employees' salaries for room and board, there are no minimum standards for the food and accommodation that the employer must provide. Live-in caregivers have been housed in sub-standard facilities, such as laundry rooms, and fed inadequate or culturallyinsensitive food. ${ }^{74}$ Many domestic workers complain of a lack of privacy, loneliness and isolation, which "gnaws" at their mental health. ${ }^{75}$ Even Madulid found the loneliness hard to bear. "Being away from my family was the biggest sacrifice I made," she recalls. "It was tough when your immediate family was not around when you needed someone to talk to. Also at that time I didn't have any friends yet and it was a bit challenging being alone."

Despite the LCP's staunch assertion to domestic workers that they "have the right to privacy in your home...you should ask for a lock on the door of your room as well as a key to the house where you live and work," domestic workers complain of employers rifling through their personal belongings or inviting guests to stay in their bedroom. They've also complained of being locked out of their employer's house if they do not arrive at the home before a designated time. ${ }^{76}$ Some workers have been asked to go to extraordinary lengths for their employers, such as the Filipina domestic worker who donated her kidney to her sick employer in Toronto. Frustrated with the Canadian health

\footnotetext{
${ }^{74}$ Audrey Macklin, "Foreign Domestic Worker: Surrogate Housewife or Mail Order Servant?" McGill Law Journal. 37.3 (1992): 1.

${ }^{75}$ The Philippines-Canada Human Resource Development Program. Uneven Gains. 25.

${ }^{76}$ "Frequently asked questions: Working temporarily in Canada" Citizenship and Immigration Canada 31 Mar. 2007, 01 Dec. 2007. <http://www.cic.gc.ca/english/information/faq/work/caregiver-faq01.asp>
} 
care system, the employer claimed she was part of the family and asked for help. The domestic helper obliged. ${ }^{77}$

"I can't speak to specific cases," says Norris after hearing the allegations. "But if you speak to 10,11 caregivers versus the 5,000 that came in from the Philippines, I'm sure you would find an interesting variation of stories." The government values the temporary workers who come to Canada, she insists. "We don't just leave them high and dry. I think that some of them feel abandoned but making sure that they are not abused is a priority for the government."

The continuous vulnerability of the workers takes its toll, says Denise Spitzer, a Canada Research Chair in gender, migration and health who researches the health impacts of the LCP. "We do see a trend where people are finding that their evaluation of their health declines after they leave the LCP." Former nannies complain of general body aches and malaise along with diabetes and hypertension, says Spitzer. "I tend to see those kinds of complaints as being the embodiment of inequality."

Fifty -two countries have signed the International Convention for the Protection of Migrant Workers and their Families. Canada has thus far refused to sign, arguing that the LCP protects foreign domestic workers from abuse and exploitation. ${ }^{78}$ In reality, argues Velasco, "Canada is not the compassionate country that it is portrayed to be internationally." 79 Domestic workers have complained of being subject to various forms

\footnotetext{
${ }^{77}$ San Juan, 4.

${ }^{78}$ Velasco, Filipino Workers 135.

${ }^{79}$ Velasco, Fight Back 162.
} 
of abuse, ranging from insults and threats, to physical abuse from children when they do not get their wishes, to sexual harassment and assaults. ${ }^{80}$

The blatant lack of protections for domestic workers is legislated through the LCP, argues migrant welfare activist Judith Ramirez, because it structures a double standard between "citizen" and "migrant" so as to enable "modern-day slavery." must be noted that other countries are ahead of Canada when it comes to protecting the rights of domestic workers. In Hong Kong, contracts between employers and domestic workers are subject to regular monitoring and review. ${ }^{82}$ The minimal provisions required include minimum wage, one rest day per week, 7-day paid leave, 11 statutory holidays per year, free passage to and from their home country, insurance, medical and dental benefits, sickness allowance, work clothes and food allowances if they are not receiving household meals. $^{83}$

The perception of Canada as a just country is challenged by racial and class discrimination against Filipina domestic workers. The common practice that domestic workers call "apartheid" means they are not allowed to share eating utensils, drinking glasses, toiletries and laundry with their employers. Prior to being accepted in the program, domestic workers must pass medical examinations, giving this practice little basis other than cultural or racial biases. ${ }^{84}$ While domestic workers are required to attend

\footnotetext{
${ }^{80}$ The Philippines-Canada Human Resource Development Program, 26.

${ }^{81}$ Ramirez, 15.

${ }^{82}$ The Philippines-Canada Human Resource Development Program, 22.

${ }^{83}$ Ibid.

${ }^{84}$ Ibid.
} 
pre-departure training and orientation sessions before stepping foot in Canada, employers have no similar obligation to attend sessions, denying them of the chance to deepen their understanding of cross-cultural differences and their responsibility to protect the rights of domestic workers.

During the course of her research, Spitzer says she has talked to hundreds of caregivers and heard dozens of horror stories. They range from the non-payment of wages to workers being kept on a trial basis to racist comments and treatment. In northern Alberta, she discovered a new trend among single fathers working in the resource industry. "They will be working five days a week, or even weeks at a time in a work camp, and [caregivers] will be expected to take care of the children 24 hours a day, for weeks at a time." Her list of horror stories continues. "Of course, verbal abuse, physical abuse and rape," she says. "I've talked to at least two people who were raped by their employers, one woman on her first night in Canada, another person in a rural area by a prominent member of the community."

The plight of live-in caregivers has prompted their supporters to advocate that the live-in requirement be dropped from the LCP, but Norris defends this condition. "It allows them to learn the culture and adapt to the culture without having to worry about looking for residence and worrying about where to put their family or what schools to go to - it gives them that three-year time frame to adapt to society and then bring their families over and settle," she says. Ferrar adds that she appreciated the live-in condition. "It's one good thing about the LCP. You know what to expect when you get to Canada. You know you'll be living with a family. You know what your salary is going to be. You know how many children you'll have to take care of." 
The peculiar status of domestic workers as neither conventional workers nor family members further compromises their ability to assert their rights. Gifts tend to foster a relationship based on gratitude and often dissuade workers from tackling issues of wages and workload. In other cases, domestic workers have been accused of stealing items that were given to them as gifts. ${ }^{85}$ Velasco recalls that throughout her experiences as a domestic worker, "even the most liberal employer treated me like I was an object that she owned" and constantly reminded her that they had given her the opportunity to work in Canada. ${ }^{86}$ In Ferrar's case, she says that while she was treated like a family member, she had to respect the line between employer and employee. "You have to know where you stand and you have to act accordingly," she says, adding "it's the same thing as any other job."

Employers often capitalize on the domestic workers' desperate need for a job. An emerging trend, called sharing of nannies, provides domestic workers to families who couldn't otherwise afford a caregiver. As a result, the caregiver has more than one employer, double the workload but no corresponding pay increase. ${ }^{87}$ Another disturbing trend has been the practice of asking domestic workers to undertake a trial period, where they work without pay for a specific time. While this practice is illegal in Canada, caregivers have complained of being coerced into these arrangements. The alternative is unemployment, which endangers their opportunity to apply for landed immigrant status and threatens their financial viability. "If you pass three years and haven't made your 24

\footnotetext{
${ }^{85}$ Ibid., 24.

${ }^{86}$ Velasco, Fight Back 160.

${ }^{87}$ The Philippines-Canada Human Resource Development Program, 24.
} 
months of caregiving, you are in big trouble," says Ferrar. "You'll be sent home," she says.

The myth of Canada as a country where workers' rights are enshrined suggests that labour industries are well-regulated. While the placement agencies that connect Filipina women to domestic jobs in Canada are regulated, their operations are virtually unmonitored. Ontario bests most Canadian provinces by requiring placement agencies to hold a license, but licensing is contingent on merely paying an annual fee. Domestic workers have complained of placement agencies charging illegal fees, processing fraudulent applications and placing domestic workers with employers that have violated workers' rights in the past. ${ }^{88}$

The LCP's material promises are backed by Canada's continuous promotion of itself as safe, tolerant haven for cultures from around the world, yet Filipina domestic workers who arrive in Canada find themselves continually marginalized as poor, racialized women from the Global South. ${ }^{89}$ Velasco had long dreamed of working in Canada because she had "heard a lot of positive things about Canada, that it was a more open, democratic and welcoming country to immigrants. I was also impressed by its social policies and programs." 90 Her beliefs about multicultural Canada didn't involve the LCP, which works to continually exclude poor women of colour from Canadian society. The LCP creates non-citizens, says academic Rita Dhamoon, who are defined by their lack of "basic citizenship rights, including the choice of employer and domicile,

\footnotetext{
${ }^{88}$ Bakan and Stasiulis, Making the Match 321.

${ }^{89}$ Nandita Sharma, Home Economics: Nationalism and the making of "Migrant Workers" in Canada (Toronto: University of Toronto Press, 1992) 24.

${ }^{90}$ Velasco, Fight Back 158.
} 
access to social entitlements, freedom of mobility and the ability to grieve workplace discrimination." $" 91$ Although these women retain Filipino citizenship, the capacity and willingness of their home nation to speak out or take action on their behalf is ineffectual. ${ }^{92}$ Ferrar came to expect nothing from the Filipino government. "A Filipino nanny can't expect the Philippine embassy to help them with their immigration papers," she says. "You can't expect them to do anything about it. These are diplomats. And they are very diplomatic," she adds, carefully choosing her words.

The status of foreign domestic workers stands in sharp contrast to the citizenship rights of their employers - often white, middle- to upper-class wealthy professional couples with children - revealing what academic Sherene Razack calls the "racialized structure of citizenship that characterizes contemporary Canada. ${ }^{" 93}$ Norris insists that this is absolutely not true. Live-in caregivers, she says, "are recognized as Canadian citizens and have every single right as Canadian citizens to make their complaints and they are encouraged if there is an abusive case to make their complaint and to change employers."

In her book, Home Economics, Nandita Sharma argues Canada has a history of recruiting temporary migrant workers who are prevented by government policy "from ever becoming part of the Canadian family."94 This largely hidden aspect of Canadian society has rapidly expanded over the past 30 years, paralleling Canada's rise to prominence as the multicultural mosaic. The myth of Canada as multicultural haven started in the late 1960s when Canada opened its doors to successive waves of

\footnotetext{
${ }^{91}$ Rita Dhamoon "Negotiating Citizenship: Migrant Women in Canada and the Global System" Labour 59(2007): 268 .

${ }^{92}$ Stasiulis and Bakan, Negotiating Citizenship 113.

${ }^{93}$ Razack, 5.

${ }^{94}$ Sharma, 78 .
} 
newcomers from the Global South who were eventually granted full citizenship. The government paired this welcome with the funding of a broad range of programs designed to help newcomers integrate into Canadian society while retaining their own cultural identities. The resulting model of multiculturalism has been lauded around the world, says Ramirez, as an "enlightened approach to immigration and held up as an example to be emulated by countries that have been less successful than Canada in integrating large numbers of immigrants into their societies." ${ }^{95}$ While enabling the state to manage cultural differences, multiculturalism in Canada has essentially granted power to the dominant group to define, tolerate and limit differences. ${ }^{96}$ The degree and form that this tolerance assumes is in a constant state of flux, depending on the needs of the project of nation-building. ${ }^{97}$ This is evident in the fact that just as Canada was opening its door to skilled immigrants from around the world; it was also recruiting ever-increasing numbers of temporary workers, whose treatment by the state, says Sharma, "reveals a far less enviable picture."98 The policies that govern the lives of temporary workers "institute a permanent threat of deportation, unchecked working conditions and forced living circumstances" resulting in an "indentured or captive labour force." 999 Contrary to Canada's self-serving reputation of being a land that welcomes everyone equally regardless of race, government figures show that between 1973 and 2004 more than three-quarters of the workers recruited to Canada were migrant workers from the Global

\footnotetext{
${ }^{95}$ Ramirez, 14.

${ }^{96}$ Eva Mackey, The House of Difference: Cultural Politics and National Identity in Canada (London: Routledge, 1999): 70.

${ }^{97}$ Mackey, 70.

${ }^{98}$ Sharma, 34.

${ }^{99}$ Dhamoon, 269.
} 
South with temporary status and no access to permanent residence and Canadian citizenship. ${ }^{100}$ Sharma uses this data to argue that Canada's international reputation for racial tolerance masks government policies that "deny many migrants access to the entitlements of permanent residency and, therefore, Canadian citizenship while recruiting them to work in Canada under conditions deemed unconstitutional for Canadians.",101 This side of the Canadian mosaic is so deeply hidden that often domestic workers are not even aware of it. As Velasco points out, they are often so grateful to have a job in Canada that they believe they "owe" something to their employers because they were given this "opportunity." She continues, "it is difficult sometimes for many domestic workers to recognize that we are here because they need us. ${ }^{\prime 102}$ It is this reasoning that leads former workers to speak softly about their experiences in the LCP. "You have to be careful of what you say," explains Ferrar. "We do not want the caregiver program to be scrapped. It would be not be beneficial to Filipinos if the program couldn't continue." It is this attitude that Spitzer finds distressing. "I've sometimes heard truly horror stories—not from everybody, but many horror stories - and you ask people at the end was it worth it, and everyone at the end says yes," she says, her voice rising. "I think we have to ask ourselves why. Why is that acceptable? Why is that tolerable for us? How can we as citizens and as taxpayers, support a program that compels people to undergo two or three years of servitude, in order to be able to remain in this country?"

\footnotetext{
${ }^{100}$ Sharma, 133.

${ }^{101}$ Ibid., 87.

${ }^{102}$ Velasco, Fight Back 163.
} 
The LCP's lure is heightened by the state's consistent efforts to encourage immigration by promoting Canada as a land of opportunity. ${ }^{103}$ The Canadian government and private employment agencies have continually insisted that the LCP provides an invaluable opportunity for the advancement of citizenship rights for female migrants from the Global South. "The neat thing about the live in caregiver program is that it is one of the only programs that as a temporary foreign worker you can apply for permanent residence and bring over your family," says Norris. Others have posited the LCP as an ideological form of foreign aid. ${ }^{104}$ Yet few Canadians would willingly agree to work as domestic workers, as it is associated with inferior status, poor remuneration and difficult working conditions. In the quest to obtain formal Canadian citizenship, say sociologists Stasiulis and Bakan, domestic workers ironically fill "one of the most vulnerable noncitizenship niches constructed on an international scale." ${ }^{, 05}$ Ferrar admits that being a caregiver, "is not the ideal way of living." She adds, "but it depends on your life situation before you immigrate. I came to Canada to have a better life. It's a short-term sacrifice for a long-term gain." Yet when Filipina domestic workers fail to capitalize on the many opportunities within Canada, the LCP blames it on personal shortcomings rather than systematic hierarchies of power, stating in its material "you will improve your chances of getting another job if you have worked in one job for a fairly long time."106

\footnotetext{
${ }^{103}$ Mackey, 34.

${ }^{104}$ Sedef Arat-Koc, "Immigration policies, migrant domestic workers and the definition of citizenship in Canada" Deconstructing a Nation: Immigration, Multiculturalism and Racism in 90s Canada. Ed. Vic Satzewich (Halifax:Fernwood, 1992): 238-9.

${ }^{105}$ Stasiulis and Bakan, Negotiating Citizenship 122.

106"'The Live-In Caregiver Program: Extending Your Stay" Citizenship and Immigration Canada 22 Jun 2007, 01 Dec. 2007 <http://www.cic.gc.ca/english/work/caregiver/extend-stay.asp>
} 
The myth of Canada as a land of opportunity is mediated in two ways in the lives of Filipina domestic workers. The first is through class and the low value accorded to domestic work, reflected in the wages and immigration status of domestic workers. From paperwork and airfare from the Philippines to their arrival in Canada, the total cost of landing a job in Canada can run as high as US\$8,300. Additionally, applying for permanent residence and sponsoring one's family may range from US $\$ 2,000$ to US\$10,000. ${ }^{107}$ Along with the need to support their family back home financially, domestic workers bear the burden of repaying this cost, a near impossible feat given the wages they earn. Their low wages stem from the minimal value ascribed to domestic work, particularly that for which Canadians import foreign workers. This perception hampers the ability of domestic workers to use their caregiving experience to gain footing into Canada's job market once freed from the LCP. The integral relationship, on the other hand, between domestic work and the functioning of the economy, has gone unrecognized, reinforced by Canada's immigration application forms. In 1992, domestic work earned a mere two out of 10 points and zero points in terms of occupational demand, a hypocritical stance, Macklin writes, considering that the federal government actively recruits them. At this time, if domestic workers were to apply to Canada as independent migrants, they would have no chance of earning the requisite 70 points for admission to Canada. ${ }^{108}$ Their only hope for gaining entry is bypassing the points system entirely by applying to the LCP.

\footnotetext{
${ }^{107}$ Cecilia Tumolva, and Darla Tomeldan, "Domestic Workers and Caregivers' Rights: The Impact of Changes to BC's Employment Standards Regulation," Canadian Woman Studies. 23.3/4 (2004): 154.

${ }^{108}$ Macklin, On the inside Looking In 742-743.
} 
The second reality that discounts Canada as a land of opportunity for Filipina domestic workers, says Ramirez, is the government policies that seek to keep "migrant workers temporary on a permanent basis and deprive them of the geographical mobility and choice of employment enjoyed by Canadian citizens." 109 The lure of landed status brings highly-educated women from the Philippines to Canada with the dream of fulfilling their two years of domestic work, obtaining landed status in Canada and finding meaningful work in their area of speciality. Yet those who gain Canadian citizenship often remain segregated in jobs in homecare, laundry, janitorial, telemarketing, data entry services and factory work, despite the fact that Filipinas are one of the most highlyeducated immigrant groups in Canada. ${ }^{110}$ While many of the women who arrive as domestic workers were trained as teachers, nurses, accountants and engineers, their credentials are often not recognized in Canada. Velasco calls becoming a domestic worker in Canada "snapping the bait" lamenting that "now we have to remain in these jobs that are essentially domestic servitude. We discover this systematized compartmentalization into jobs for people of colour wherein we suffer the disappearance and devaluation of our skills and experience."111 Former domestic workers attribute their measly job prospects beyond the LCP to the consistent deskilling of domestic work, a process described as "unseen violence" by Velasco. ${ }^{112}$ This deskilling has been attributed to a loss of confidence while working as caregiver but also due to their financial situation. "The promise of being able to regain their professional status and fulfill the dreams of

\footnotetext{
${ }^{109}$ Ramirez, 14.

${ }^{110}$ Velasco, Filipino Workers 137.

${ }^{111}$ Ibid.

${ }^{112}$ Ibid., 136.
} 
being an educated professional in Canada are often stalled or derailed," says Spitzer, "especially because women will tend to forego their own investment in their own career paths in favour of remittances to family members or bringing family members to Canada." Often they take a short 6-month part-time or full-time course that enables entry into the most casualised and vulnerable parts of the employment sector; home support, elder care and nurses' aid. ${ }^{113}$ After her time in the LCP, Ferrar, trained as a midwife in the Philippines, took a six month diploma program and landed a secretary job. Madulid, who has a commerce degree from the Philippines, took a three-month program at a college and now works as an assistant to an accountant.

Canada as a land of opportunity suggests that everyone has equal opportunity to protect the sanctity of their family. But critics say the hypocrisy of this official state discourse is revealed through the racialization of the right to have a family. Approximately one-third of the women who came to Canada through the LCP in 2003 left children and partners behind in the Philippines with the median time of separation being five years. ${ }^{114}$ The inherent contradiction of separating a mother from her family in order to care for another's family is heightened by the fact that most Filipina domestic workers come to Canada simply to provide financial support for their family and secure a better future for their children. ${ }^{115}$ The decision to work thousands of miles away from their family is often framed in government discourse as a choice, replicating what Razack calls the "amnesia that allows white subjects to be produced as innocent, entitled, rational

\footnotetext{
${ }^{113}$ Geraldine Pratt "BETWEEN HOMES: Displacement and Belonging for Second-Generation FilipinoCanadian Youths," BC Studies, 140(Winter 2003/2004): 48.

${ }^{114}$ Ibid., 47.

${ }^{115}$ Geertje Lycklama, "Trade in Maids: Asian Domestic Helpers in Migration Theory and Practice" Trade in Domestic Helpers: Causes, Mechanisms and Consequences (Kuala Lumpur: Asia Pacific Development Centre, 1989) 43.
} 
and legitimate" and in ignorance of the state's continued decision to deny entry to the children and partners of foreign domestic workers. ${ }^{16}$ As pointed out by Bakan and Stasiulis, "the 'family' that is to be protected from unnecessary state intervention is the middle-class white Canadian family. The same state shows no hesitation in disrupting the lives of usually poor, rural women from developing countries."117

Domestic helpers who are able to gain citizenship and re-unite their family in Canada might find that while a romantic concept on paper, family reunification is much more difficult in reality. Their family, who have become accustomed to living a middleclass life in the Philippines, are often thrust into the lives of working poor in Canada. They are forced to reconcile years of separation from their parent within a span of a few minutes. Abigail Yao left the Philippines in 1990 to work in Canada as a domestic worker, leaving her two daughters in the care of her mother. After 15 years of trying, she finally managed to bring over her two daughters, aged 16 and 18 , to Canada. "But my daughters hardly know me," she laments. It's been two years since they reunited, "and we're still not comfortable with each other." Abigail readily admits that reconnecting with her daughters is the hardest thing she has ever had to do.

Still despite such heartbreaking stories, Filipinas continue to arrive in droves on Canada's doorstep, motivated by the chance to support their families back home and armed with dreams of one day of becoming part of the Canadian family. "There are things about the LCP that can be improved," says Ferrar. "But for now, we take what we can and make the best out of it. That's what helps us to survive." Their continued strength and determination in the face of institutional and overt discrimination based on

\footnotetext{
${ }^{116}$ Razack, 17.

${ }^{117}$ Bakan and Stasiulis, Making the Match 17.
} 
race, class and gender is best summed up by Velasco: "the Filipino workers are like bamboo trees. We are very flexible. We don't break easily."118

${ }^{118}$ Velasco, Filipino Workers 139. 


\section{Chapter 2: Transnational Families}

Every night, before Emily Jane Salayon goes to bed, she kneels for prayers. She only ever asks God for one thing; to take care of her family and keep them healthy and safe until she returns home to the Philippines. It always worked, until January 17, 2008.

While in Shanghai teaching English, Salayon received a phone call late at night from her husband. Her seven-year-old son, Raphael, had passed away quietly minutes before.

Two days later she returned home to the Philippines to bury her son. "I don't know what happened," she says, her eyes tearing up. "He was a cancer survivor, you know." Rigorous chemotherapy and a fierce will to live had beaten off cancer once nobody thought it would return.

It was the bills from his medical care that sent Salayon overseas to work. As she had studied English in university, she had little problem landing a job teaching English in China. "I thought it would be okay to go. The doctors told me that he was fine." Excited to lift her family out of the debt that was overshadowing their daily lives and confident about leaving her two sons in the hands of her husband and mother-in-law, she left.

She had only been gone four months before she came home. Twenty months remain in her teaching contract in China -and her massive bills have yet to be paid -- but she has no desire to return. "I don't know what to do. I don't want to go back." Her husband doesn't want her to go back either. "He worries now that something could happen to our four-year old son," says Salayon. Instead she spends her days pacing her 
home in the Philippines, agonizing over her decision to leave. Would things have been different if she had stayed? Could she have kept her son alive?

The prevalence of migration in the Philippines has given rise to a new family structure: the transnational family, whose immediate members are located in two or more nation states. ${ }^{119}$ In the Philippines, where more than two-thirds of the migrant workers are women, transnational families mean that mothering often happens from a distance. ${ }^{120}$ It's a hard pill to swallow in this conservative country, where family is of utmost importance. "It's not very easy," says Regina Sosing Ferrar who left her parents in the Philippines to come to Canada more than 15 years ago. "Especially for Filipinos. We are so attached to our families. It's so sad that we have to go through this but we are strong." A prolonged visit home can be painful too. "Its hard man -it's so hard," says Jose Pelayo, who has spent the last three years serving in the U.S. navy. "Nothing hurts more than that trip to the airport. I hold my daughter and my wife so tight and we all cry. I wait until the last possible minute to get on the plane. When the plane takes off, I stare at my country for as long as I can from the window—because I know that I won't get to see any of that for years."

Transnational families are neither new nor unique to the Philippines. Instances of families being spread across the world have been well-documented in Mexico, Haiti and among earlier immigrants to the United States. What is new in the Philippines is how

\footnotetext{
${ }^{119}$ Rhacel Salazar Parrenas "Migrant Filipina Domestic Workers and the International Division of Reproductive Labour," Gender and Society, 14.4(2000):575.

${ }^{120}$ Rhacel Salazar Parrenas, "Human Sacrifices: What Happens When Women Migrate and Leave Families behind? The Case of the Philippines Raises Some Troubling Questions," The Women's Review of Books 19.5(2002): 16 .
} 
many families are transnational, a number that is multiplying every_day. Transnational families have become so entrenched in local culture that a Christmas commercial for a popular local fast-food restaurant featured an OFW father coming home. The young son, who hadn't seen his father in years, didn't recognize him and shied away from his father's consistent advances. Unfazed, the father scooped up his son while the announcer wished everyone a Merry Christmas full of family reunions.

Not all OFWs head transnational families. Most of those who leave the Philippines are single, hoping to return home and marry after fulfilling their filial duties of remittances and taking advantage of the chance to see new lands. Others use overseas foreign work as an excuse to duck out of marriage and tradition. But a substantial chunk of the OFWs that leave the Philippines every day to work abroad do so solely in the interest of providing a better life for their children.

Endeavouring to care for their families, Filipinos face the ultimate paradox. The best jobs, in terms of being most able to secure their children access to education, healthcare and most likely upward mobility, lie worlds away, in Hong Kong, the Middle East, Europe and North America. So in order to financially care for their families, they make the ultimate sacrifice, moving far away, signing contracts for as long as five years with little time off and no provisions to return home for a visit. Often they are so dedicated to sending back as much money as possible that they are unable to afford the luxury of a visit home.

Migrant workers are often conceptualized as suspended in time, working and waiting to return home to their beloved Philippines. But the truth is that a number of Filipinos love their overseas home and hesitate to return to the Philippines. Some express 
shock when they do go back at how poor the Philippines is, and how dirty Manila is, compared to where they live now.

A Filipino domestic worker named Molly, interviewed by academic Nicole Constable, enthusiastically professed her love for Hong Kong, admitting readily that she did not miss her three-year-old son. "I don't miss him," she says, "because I have never lived with him!"121 Her maternal grandmother and her husband have looked after him since he was one week old. She went on to explain that she had much more "fun and freedom" than she would in the Philippines, where she would have to "learn to plant rice." 122 Instead Hong Kong and overseas migrant work had given Molly a chance to be a mother and a wife on her own terms, an empowerment that would be impossible if she had stayed in male-dominated Philippines. Other migrants echo the freedom she's found overseas. "For some people [migration] is a way of getting away from an abusive spouse," says Denise Spitzer, a Canada Research Chair in gender, migration and health, adding "some women who are lesbians say it's a bit easier to be living abroad."

As many Filipinas were working full time in the Philippines as well as heading families and households, their lives as domestic workers abroad sometimes found them doing less work than they were used to at home. ${ }^{123}$ This was the case of Vanessa, a domestic worker in Taiwan who used to manage a bookstore in the Philippines. "In the Philippines, I am exhausted. I wake up early. I cook. I wash," she told academic PeiChia Lan. "When my children come home after school, I am still working. They heat the

\footnotetext{
${ }^{121}$ Nicole Constable, "At Home but Not at Home: Filipina Narratives of Ambivalent Returns," Cultural Anthropology, 14.2(1999):215.

${ }^{122}$ Ibid., 215.

${ }^{123}$ Pei-Chia Lan, "Maid or madam? Filipina migrant workers and the continuity of domestic labor," Gender and Society, 17.2(2003):192.
} 
food I cook in the morning. Here, [the work is] easy. In the afternoon, I finish my work. I can just rest, watch HBO like this [crosses her legs and puts her feet on the table]. So look at me [points at her body], I have gained 10 pounds in the last six months.", 124

Some, like Filipina journalist Connie Veneracion, have applauded the women's liberation afforded by migration, writing in her column for the Manila Standard Today, "Until around 30 years ago, married women and mothers did not work abroad and leave their husbands and children behind. It took the threat of starvation for Filipinos to reconsider many of their outmoded notions about women and womanhood." 125 Spitzer says migration has the potential to be tremendously liberating. "Some people have done this because it's an adventure and it's a challenge and that makes you feel good about it. They have done amazing things, survived, flourished, found other people to connect with and all of those things can make people feel very good about themselves."

The liberating experiences of OFW women are paralleled with a literature of loss. Working for the past year and a half as a domestic worker for a family in Toronto has been a good experience for Joy Ann Guilermo, except for being apart from her eight-year old daughter. "Before I go to bed every night, I think of her. At that time of the day, she might be having breakfast or walking to school. I wonder who she's talking to, what she's eating. She's so far away. I miss her so much-it's so hard," she says. After a few seconds pause, she adds, "Pray for me that Canada will let me bring her with me." As Rosemary Samaniego, a widowed mother of three and a domestic worker in Italy since 1991, told Parrenas:

\footnotetext{
${ }^{124}$ Ibid., 192.

${ }^{125}$ Connie Veneracion, "Roots to Grow and Wings to Fly," Manila Standard Today, 29 Jan. 2008: A5.
} 
When the girl that I take care of calls her mother "Mama," my heart jumps all the time because my children also call me "Mama"...I begin thinking that at this hour I should be taking care of my very own children and not someone else's, someone who is not related to me in any way, shape or form... The work that I do here is done for my family, but the problem is they are not close to me but far away in the Philippines. Sometimes you feel the separation and you start to cry. Some days I just start crying while I am sweeping the floor because I am thinking about my children in the Philippines. Sometimes when I receive a letter from my children telling me that they are sick, I look up out the window and ask the Lord to look after them and make sure they get better even without me around to care after them. (starts crying). If I had wings, I would fly home to my children. Just for a moment, to see my children and take care of their needs, help them, then fly back over here to continue my work." 126

If the women are abroad working, what happens to the children left behind?

Their care often falls into the hands of female relatives, such as aunts and grandmothers, or in the hands of the eldest daughter in the migrant workers' family. ${ }^{127}$

The care duties also go to women who are too poor to emigrate. Some OFWs consider this a better means of providing care for their children, as they find it difficult to evaluate or criticize the care offered by relatives. Kin are often no cheaper than hired caregivers, as Filipino culture requires migrant parents to provide relatives with financial returns, referred to as utang na loob (debts of gratitude). ${ }^{128}$ The OFWs prefer to leave their children in the hands of local women who are less expensive to hire and not likely to leave the country themselves. ${ }^{129}$

\footnotetext{
${ }^{126}$ Rhacel Salazar Parrenas, "Mothering from a Distances: Emotions, Gender and Intergenerational Relations in Filipino Transnational Families," Feminist Studies, 27.2(2001):371.

${ }^{127}$ Elaine Bell Kaplan, "I don't do no windows: Competition between the domestic worker and the housewife," Competition: A feminist taboo?, eds. V. Miner and H.E. Longino, (New York: The Feminist Press, 1987).

${ }^{128}$ Lan, Maid or Madam 194.

${ }^{129}$ Dean Tiburcio Alegado, "The political economy of international labour migration from the Philippines," diss., University of Hawaii, Manoa, 1992.
} 
Their search for care to replace their own has become a booming industry in the Philippines. Local domestic service constitutes one of the largest categories of paid work for women. ${ }^{130}$ Many of these local domestic workers are rural women, recruited to work in the city to escape poverty in the provinces and lured by the prospect of accessing an urban, middle-class life. Households in the Philippines that are capable often hire several domestic workers who are specialized into different jobs. Many have yayas (nannies) and helpers (household workers) who live with them, in addition to cooks and laundry women who don't live with them. ${ }^{131}$

Parrenas calls this the "international transfer of caretaking," enabling classprivileged women to purchase the low-wage services of Filipino domestic workers, who in turn purchase the even-lower wage services of women left behind in the Philippines. She illustrates the term with the case of Carmen Ronquillo, a domestic worker for a professional woman in Rome, Italy. As she tells Parrenas, coming to Rome to be a maid was a difficult transition, as she "was not used to the work. You see, I had maids in the Philippines. I have a maid in the Philippines that has worked for me since my daughter was born 24 years ago. She is still with me."132 As a domestic worker in Italy, Ronquillo earns around USD\$20,000 a year, easily allowing her to afford a domestic worker that she pays around USD $\$ 480$ a year.

Aside from sending money, most OFW mothers remain actively involved in their children's lives from a distance - sometimes calling several times a week-showing their

\footnotetext{
${ }^{130}$ Elizabeth Uy Eviota, The political economy and gender, women and the sexual division of labour in the Philippines. (London: Zed Books, 1992) 8.

${ }^{131}$ Lan, Maid or Madam 194.

${ }^{132}$ quoted in Parrenas, International Division of Reproductive Labour 570.
} 
love by attempting to help their children solve problems related to homework and their peers. Studies have consistently characterized transnational motherhood by practices such as sending children to private schools, purchasing expensive gifts and providing children with generous allowances. ${ }^{133}$ Migrant women continue to be "socially defined as primary caregivers," argue Pierrette Hondagneu-Sotelo and Ernestine Avila in their exploration of transnational motherhood, and so "have to distinguish their transnational motherhood from an act of abandonment or disowning of their children."134 They are left with little option but to turn this love into a commodity, as evidenced by the words of Ruby Mercado, a domestic worker in Italy. "All the things that my children needed I gave to them and even more because I know that I have not fulfilled my motherly duties completely. Because we were apart (since 1983), there have been needs that I have not met. I try to hide that gap by giving them all the material things that they desire and want. I feel guilty because as a mother I have not been able to care for their daily needs. So because I am lacking in giving them maternal love, I fill that gap with many material goods..."135

The fathers of these children often remain uninvolved in their children's lives, whether out of disinterest or because they themselves are working in other parts of the Philippines and are able to return home only on weekends.

The misery of being away from children is exacerbated by the reality that they are looking after the children of others. As Guilermo confesses, "I feel guilty all the time.

\footnotetext{
${ }^{133}$ Pierrette Hondagneu-Sotelo and Ernestine Avila. “ 'I am here, but I am there': The meanings of Latina transnational motherhood," Gender and Society 11.5(1997).

${ }^{134} \mathrm{Ibid}$.

${ }^{135}$ Ibid.
} 
When I put my employer's two daughters to bed, I think about my daughter who doesn't have a mom to do that. When I clean out a cut on one of the girl's knees, I wonder if my daughter has anyone to do that when she falls down." Sometimes she not sure why she's across the world, she says, looking after somebody else's children while her daughter grows up without a mother. "If I didn't need the money, I would never do this. I would be with my baby."

Scholars have noted that what results is a phenomenon called "displaced mothering" or "diverted mothering" where the migrant mothers find emotional comfort in being surrogate mothers. ${ }^{136,137}$ By being the mothers to the children of their employers, write Brenda Yeoh and Shirlena Huang in their study of this phenomenon, migrant mothers "gain self-esteem in negotiating their identities vis-à-vis their employers. They are deeply touched when employer's children profess to prefer them over their biological mothers, evidence that empowers them and restores faith in their capabilities of motherhood despite having left their own children to work." 138 This phenomenon is exactly how Barbara Clausen remembers her domestic worker. "When we were in L.A., my mother was in the later stages of cancer. We hired a caregiver for her and this lady from the Philippines - the nicest, warmest lady you could imagine — went way above and beyond what was expected of her," she recalls. "She would say that my mother reminded

\footnotetext{
${ }^{136}$ Parrenas, International Division of Reproductive Labour 572.

${ }^{137}$ Sau-Ling Wong, "Diverted mothering: Representations of caregivers of color in the age of "multiculturalism," Mothering: Ideology, experience and agency, eds. E.N. Glenn, G. Chang and L. Rennie Forcey, (New York:Routledge, 1994) 69.

${ }^{138}$ Brenda Yeoh and Shirlena Huang, "Singapore women and foreign domestic workers: Negotiating domestic work and motherhood," Gender, migration and domestic service, ed. J. H. Momsen, (New York: Routledge, 1999) 297.
} 
her of her mother. And if she couldn't look after her own mother, she might as well look after mine."

While Filipinos unfailingly conceptualize OFWs as modern-day heroes who are sacrificing their own lives in order to better those of their family and the country, there is considerable national alarm about the consequences of transnational families. While Filipino culture considers it honourable for women to delay or sacrifice marriage in order to go abroad and send home money to parents and siblings, the sentiment is not extended to women who leave their children to work abroad. ${ }^{139}$ "I understand why they do it, but how can they do it?" asks Rhoda Banteras, a teacher who has opted to stay in the Philippines to raise her children. "Everybody knows that children with a mother abroad go crazy, cause trouble, get pregnant and start taking drugs." Her comments are echoed by Filipinos across the country. Almost everyone can tell you stories about OFWs who left behind children who went uncared for. These households, encouraged on the one hand by economic globalization, are discouraged by traditional Filipino expectations of cohabitation in the family. ${ }^{140}$ "They're in this double-bind because even though they're considered to be doing their familial duty, there's still a notion that women are meant to be at home, especially if they have children. They are meant to be caring for their children directly," says Spitzer. Proof, she adds, is in the fact that there are support groups and programs for children whose fathers are migrant workers, but nothing for children whose mothers are migrant workers.

\footnotetext{
${ }^{139}$ Constable, 212.

${ }^{140}$ Ibid., 381.
} 
OFW mothers are often demonized in the media as bad mothers who have abandoned their children, leaving them to become liabilities to society. ${ }^{141}$ The stereotype is not completely unfounded, says Cibella Lightfoot, an Australian aid worker in the Philippines. "Many of the street kids we work with are from families where one parent has gone abroad and left their children in the hands of someone who is incapable of caring for them." To Filipinos, says Parrenas, these women are not heroes, but "delinquent and uncaring, destroyers of home and family." in the Philippine Star said that OFW mothers were using a "materialistic approach" to child-rearing, resulting in children who are less disciplined and have fewer morals. ${ }^{143}$ Salayon, when she returned home, couldn't bear the accusing whispers and pointing. "They said my son was gone because I had left," she says, her voice shaking. "How can they say that he would be alive if I had stayed? How do they know that?"

Until the mid-1980s, the Filipino government could truthfully claim that the majority of their "economic heroes" were men or single women. But when women including many mothers -- began to dominate the flow of migration, disrupting the ideal model of a Filipino family, transnational families became a national crisis. Mothers who go abroad, says Spitzer, are "in a very ambivalent situation. Their funds obviously have a strong impact on the Philippine economy. But on the other hand they are seen as abandoning their children."

\footnotetext{
${ }^{141}$ Parrenas, Human Sacrifices 2.

${ }^{142}$ Ibid.

143“"Study shows OFWs using 'materialistic approach' to child rearing," The Philippine Star, 28 Jan. 2008:15.
} 
The perceived difference between having a mother versus a father overseas was highlighted in a survey by Victoria Paz Cruz of the Scalabrini Migration Centre, a migration think-tank based in the Philippines. While more than 80 per cent of the children she surveyed said they would advise their friends to let their parents work abroad, there was a staggering difference when the question was asked specifically for fathers and mothers. Almost 60 per cent would advise their friends to allow their fathers to go abroad, but only four per cent of children would advise that mothers be allowed to work abroad. ${ }^{144}$

Their qualitative answers explained the findings further, with one child noting, "Its better that fathers go because mothers can't do what fathers do. Mothers are closer to their children than the father. She's always present in times of difficulties and problems." ${ }^{\text {145 }}$ Paz Cruz found this point of view supported in interviews with children left behind, as the emotional toll seemed to be higher when the parent who leaves is the mother rather than the father. There seemed to be a greater understanding that the father is simply fulfilling his role as the provider, and is justified if he has to leave. In contemplating the absence of his father during his childhood, Filipino Rodney Catorce writes, "I have always thought about it, my Dad being so far away from us for more than 10 years now. I mean, how could he?...Sometimes I wonder what if Dad didn't gamble his luck abroad...Well, undoubtedly, we would not have missed him that much. He would not have missed us that much...He would have seen us grow up. Too bad, he was not able to. But then again, we would not be where we are now. We would not be living

\footnotetext{
${ }^{144}$ Victoria Paz Cruz, Seasonal Orphans and Solo Parents: The Impacts of Overseas Migration (Quezon City, Philippines: Scalabrini Migration Centre, 1987): 38.

${ }^{145}$ Ibid., 42.
} 
in our own house...I and my brothers and sisters would not be studying in great schools. Daddy would not have been a good provider... All these considered, I am glad he did. True, he is away, but so what?"146

Research has continually found that children left behind suffer the distance between themselves and their mothers through feelings of loneliness, insecurity and vulnerability and crave reuniting with their migrant parents. When Paz Cruz asked about their desire to have greater intimacy with their migrant parents, children responded "I want them to share with us in our daily life and I want our family to be complete," "so that they will be there when we need them" and "we can share our laughter and our tears." 147 The children's responses further revealed a struggle to understand why their family was separated, with Paz Cruz noting that few successfully understood their mother's decision to raise them from a distance.

Children often disagree with their mother's reasoning that the money they send back and the lifestyle they provide equals the love they are lacking. ${ }^{148}$ While 60 per cent of children surveyed do not wish for their parents to stop working abroad, they are less convinced that financial security is worth the emotional burden of separation. ${ }^{149}$

Tapping into the pulse of the Filipino migrant community is Tinig Filipino, a glossy magazine that describes itself as a "linking force around the world." It is distributed in more than a dozen countries and is mostly written by migrant workers,

\footnotetext{
${ }^{146}$ Rodney Catorce, "My Dad is Away, So What?" Tinig Filipino, June 1995: 9.

${ }^{147}$ Paz Cruz, 43.

${ }^{148}$ Parrenas, Mothering from a Distance. 376 .

${ }^{149}$ Paz Cruz, 43.
} 
serving to tie migrants around the world into one, global community. ${ }^{150}$ Loosely translated, its name means Filipino Voice and the magazine strives to provide a forum for dialogue regarding the lives of migrant workers. It's approximately fifty pages in length and is published in Hong Kong and Italy. Its multinational distribution hints at the proliferation of the Filipino Diaspora. A reoccurring theme in Tinig Filipino is the call by children for the return of their migrant parents, particularly mothers. One letter by a son reads, "Mom, come home. Even if it means that I won't get new clothes anymore, just being close to you will make me happy. Dad and I are so lonely here without you." 151 The note suggests that money and mothering are mutually exclusive and that the mother has chosen money.

A heartbreaking letter from Nina Rea Arevalo to her mother echoes this sentiment:

“...Mom, I am getting older and I need someone guiding and supporting me and that is you. I don't want to be rich. Instead I want you with me, Mom. Doesn't God say that a family should always be together through hardships and happiness? But why are you far away from us?

"Mom, Christmas is here again. That's why you should come home soon. I don't want anything else but you with me, Mom.

"Kuya and Ate [her siblings] read somewhere that Filipino workers in other shores are the heroes of our country. But Mom, come back and you will be the queen that I will be with every day.",152

\footnotetext{
${ }^{150}$ Rhacel Salazar Parrenas, "Transgressing the Nation-State: The Partial Citizenship and 'Imagined (Global) Community' of Migrant Filipina Domestic Workers" Signs 26.4(2001):1144.

${ }^{151}$ Liza Daguio, "Family Still Number One," Tinig Filipino February 1995: 40. Quotation has been translated from Tagalog to English.

${ }^{152}$ Nina Rea Arevalo, "Inay, Pasko na Naman," Tinig Filipino December 1994: 28. Letter translated from Tagalog to English.
} 
Others question the sporadic nature of visits home to the Philippines—often happening years apart. Alvin Ebona's father left for the US 15 years ago and never once visited. "I love him because he's my father," explained Alvin, "but I don't know him. He just sends me presents." Overcoming separation once reunited can be difficult, as Aimee Beboso recalls. Since she was just a few years old, her father had worked abroad in Saudi Arabia. "That's all I could remember was that my dad would disappear and come back every few years for a month," she says. "And then he would disappear again." At the time, it seemed almost normal to her. "Where I grew up, most of the men left. And they all even worked in the same plant in Saudi Arabia. We grew up in it-we thought it was normal."

They were reunited as a family in Canada when Beboso was a teenager. By that time she had realized that most people didn't have to go through life with an absentee father. She rebelled when he tried to assert his authority. "We recognized him as our dad, but we didn't really have a relationship with him. He was trying to impose 'I'm the dad — the padre de la familia-- and we would be like, no, mom's the padre de la familia," she recalls. "In high school I resented my father because I was like why are you imposing your rules on us, when mom always gave us the rules? Well you weren't there most of our lives, why all of sudden you just want to jump in? Well what about those years?" Years later, she saw things differently. "Now I have a different analysis that understands that my dad is part of a global movement and it's not necessarily his fault. I'm sure he didn't choose to leave. But to me as a child, coming from that perspective, he left us." 
The children left behind don't always believe that their OFW parents understand the sacrifices made at home to support a transnational family. Lina Galang brags that all it took was a reminder of these sacrifices to bring her seafaring husband home for good. "My son wrote to him and told him that life was too hard without him. He hated that his father wasn't there for his graduation and other big things in his life." It wasn't just her son who found it hard. "I had to be the mother and the father for all six of my kids," she says. Galang's husband, a seafarer for 15 years, came home when he realized how much his family needed him. The family spent a chunk of their savings on a hostel on the beach of Boracay, hoping that the revenue from foreigners would compensate for the loss of income. They've only been open two years, but so far their gamble has paid off. "Now we have a family that's together and have the same income," beams Galang. Much research shows that, in the long run, children with OFW mothers are often unharmed by their absence. When asked about inspiration, Therese Bascara, a college student whose mother has worked as a domestic worker since the early 1980 s, pointed out her mother to Parrenas. "She is the one suffering over there, so the least I can give back to her is doing well in school.",153

Yet the demonization of these women continues. The Filipino government is increasingly placing pressure on the women of families to return home, blatantly ignoring the reasons they migrated in the first place. There has been little questioning of the assumption that caring work is women's work, eliminating any possibility of national dialogue on the role that fathers should play in supporting families.

\footnotetext{
${ }^{153}$ Parrenas,
} 
As Parrenas writes, a reconfiguration of the gendered division of labour around the world would most easily heal transnational families. "The biggest impact of all would be for Filipino men and men around the world to start doing their share of the care work - which would reduce the demand for these service workers in the first place." 154 In absence of this, she says, the onus of caring for transnational families lies with the receiving countries. It is they, after all, who are benefiting from the separation of mothers from their families, and should be held accountable for their workers' children. In some sectors, such as seafaring, job contracts typically include two months vacation with subsidized travel home. Were domestic helper jobs around the world to adopt similar clauses, the duress transnational families experience could be lessened.

Spitzer says that countries who are importing caregivers should question their increasing demand for care work. "I think we have to ask ourselves-what is this care crisis about? Do we really have insufficient resources to address caregiving?" she asks. "Or do we have gendered expectations that say that women are in charge of this caregiving labour ergo it's their burden to deal with? Do we have workplaces that are inflexible and preclude having individuals take care of caregiving responsibilities?" Once these questions are addressed, she says the discussion can become productive. "Then, if we discover we still have a care gap, then we need to think about caregiving labour as something that we truly value."

Another possibility, mentioned earlier, is to enable domestic workers to bring their families with them. This is now permitted on a temporary basis on some countries,

\footnotetext{
${ }^{154}$ Ibid.
} 
such as Italy. ${ }^{155}$ Hampering this strategy, complain domestic workers, is the racism and xenophobia that their children would face. If they were to settle permanently, the women point out to Parrenas, "patterns of discrimination would condemn their children to service jobs in turn, whereas the reason the mother migrates in the first place is to protect her children from downward mobility.",156

From the transnational family emerges another social problem. After living away from the Philippines for years, sometimes decades, what happens when an OFW returns, especially for brief 10 or 12 day visits? Migrant mothers often complain of a loss of intimacy. As Ermie Contado explained to Parrenas:

When I came home, my daughters were teenagers already. (Starts crying.) When I saw my family, I dropped my bag and asked who were my daughters. I did not know who they were but they just kept on screaming "Inay, Inay!" [Mom, Mom!]. I asked them who was who and they said "I'm Sally and I'm Sandra." We were crying. I did not know who was who. Imagine! But they were so small when I left and there they were as teenagers..."157

\footnotetext{
${ }^{155}$ Ibid.

${ }^{156}$ Ibid.

${ }^{157}$ quoted in Parrenas, Mothering from a Distance 371.
} 


\section{Chapter 3: Gender and Migration}

When former Filipino president Ferdinand Marcos first conceived of an economy that would revive itself through the export of labour, it wasn't supposed to be about the women. The jobs he envisioned were mostly male-oriented construction and manufacturing jobs in the Middle East during and after the Gulf War. But in the 1990s, the demand for these jobs started to dry up, while women's advancement in developed nations was creating a growing demand for caregivers. So the benefits of migrant labour were passed to women who were willing to work abroad. Filipinas showed they were willing, leaving in droves and handing over the care of their children to husbands and parents. $^{158}$

"Care work is probably the biggest export of the Philippines right now," says Denise Spitzer, a Canada Research Chair in gender, migration and health. "And you cannot talk about caregiving without talking about gender."

Today two-thirds of Filipino overseas workers are women, a number that is steadily growing. ${ }^{159}$ And two-thirds of this feminized migrant workforce is employed as domestic workers, while many of the others work as nurses or in some sort of service industry. ${ }^{160}$ The export of women has worked well for the Philippines in some ways, says Spitzer. "The find is that women are better remitters than men," she says. "So it's

\footnotetext{
${ }^{158}$ Cecilia Tarcoll "Migrating 'for the sake of the family?' Gender, life course and intra-household relations among Filipino migrants in Rome" Philippines Sociological Review 44.1-4(1996).

${ }^{159}$ Parrenas, Human Sacrifices 16.

${ }^{160}$ Antonio Tujan "Health Professionals Migration and It's Impact on the Philippines" Asia Pacific Research Network 31 Mar. 2002, 24 Dec. 2007

$<$ http://www.aprnet.org/index.php?a=show\&t=journals\&i=5>
} 
very much tied into being a dutiful daughter, the good girl who remits money back home to the family."

The demand for male and female migrant labour varies across the globe, resulting in a bifurcated flow of migrants from the Philippines. Women often migrate to destinations in need of entertainment and service workers while males are deployed to areas of heavy production and construction jobs. ${ }^{161}$ Filipino men then constitute the majority of migrant workers in the Middle East, while Filipinas dominate everywhere else. In 1996 Filipinas made up almost 85 per cent of Filipino migrants in Hong Kong, more than 75 per cent in Singapore and nearly 80 per cent in Italy. ${ }^{162}$

It's a trend that has signalled a new day for this conservative, male-dominated Asian culture, heavily influenced by the machismo attitudes of their Spanish colonizers. Filipinas are migrating independently, differentiating themselves from the classic mold of migrants as they are neither dependent on men nor migrating as secondary parties. Where these women end up depends on the level of immigrant integration and policies in their receiving nations. Professional Filipinas, owing to their direct recruitment in the 1960s and 1970s, tend to be concentrated in the United States, while Filipinas in every other destination tend to be segregated in low-wage service sectors. ${ }^{163,164}$ The illegal trafficking of Filipinas has led to their concentration in sex industries, especially in Japan,

\footnotetext{
${ }^{161}$ James Tyner, "The Social Construction of Gendered Migration from the Philippines," Asian and Pacific Migration Journal 3.4(1994).

${ }^{162}$ Philippine National Statistical Coordination Board, Women and Men in the Philippines. (Makati City, Philippines: Philippine National Statistical Coordination Board, 1999).

${ }^{163}$ Yen Le Espiritu, Filipino America Lives (Philadelphia: Temple University Press, 1995).

${ }^{164}$ Catholic Institute for International Relations (CIIR). The Labour Trade: Filipino Migrant Workers Around the Globe. London: Catholic Institute for International Relations, 1987.
} 
but also in the Middle East. ${ }^{165}$ A shocking number of Filipinas have also entered Australia and countries such as Canada, Germany, Finland, Norway and the United States as mail-order brides. ${ }^{166}$

Parrenas argues that the prominent role that women play in Filipino migration is facilitated by Filipino culture and it's more egalitarian nature between the sexes as compared to most Asian countries. ${ }^{167}$ Examples abound; Filipinas have comparable access and attainment of education as compared to Filipino men, women have a high rate of participation in the productive labour force and their kinship system is bilateral. ${ }^{168}$ The Philippines has elected two female presidents in the last 20 years while other women have held positions of power in government since the country's independence.

But all is not equal. A 2003 survey showed that nine per cent of Filipino women have been victims of domestic abuse. And like women around the world, Filipinas are expected to reproduce the family life while men are expected to provide financially for the family. ${ }^{169}$

The increasing migration of women from the Philippines has highlighted the manner in which gender issues intersect with economic, cultural, social and political matters of the Philippines. ${ }^{170}$ While this crossing of borders may be liberating and

\footnotetext{
${ }^{165}$ Osteria Trinidad. Filipino Female Labour Migration to Japan: Economic Causes and Consequences. (Manila: De la Salle University Press, 1994).

${ }^{166}$ Roland Tolentino, "Bodies, Letters, Catalogues: Filipinas in Transnational Space," Social Text 48.14.3(1996): 49-76.

${ }^{167}$ Parrenas, Mothering from a Distance 381.

${ }^{168}$ Eviota.

${ }^{169}$ Parrenas, Mothering from a Distance 381.

${ }^{170}$ Yeoh, Huang and Gonzalez, 115.
} 
empowering as it gives Filipinas the chance to act as agents of change in their lives, academics Lin Lean Lim and Nana Oishi point out that "their status as women, as migrants or non-nationals, and as workers in gender segregated labour markets makes international female migrant workers particularly vulnerable to various forms of discrimination, exploitation and abuse. ${ }^{171}$ This is evident in considering the lives of domestic workers in Canada, discussed earlier, who are neither traditional employees, nor members of the family where relationships are governed by factors outside of the market. $^{172}$

The shattering of typical gender roles for the sake of economics wreaks havoc on marriages and has resulted in drastic changes in the relationships of Filipino couples. Filipino migrant women often mock their "domesticated" husbands who stay at home and perform most of the domestic tasks, calling them "househusbands" or "huswife." 173 Even more frequently, these women complain that their husbands are unable to adequately perform their tasks as househusbands, especially when it comes to budgeting to meet the needs of the house. Implicitly these women had hoped that when they crossed borders in order to provide for their families, their husbands would readily reverse roles and pick up where their wives had left off. What Filipina migrants have more often found is that there is no guarantee that their husbands will adjust to the shifting of social positions and

\footnotetext{
${ }^{171}$ Lin Lean Lim, and Nana Oishi, "International Labour Migration of Asian Women: Distinctive Characteristics and Policy Concerns." Asian Women in Migration, eds. G. Battistella and A. Paganoni. (Quezon City: Scalabrini Migration Centre, 1996) 23.

${ }^{172}$ Shirley Huang, and Brenda Yeoh, "Ties that Bind: State Policy and Migrant Female Domestic Helpers in Singapore," Geoforum, 27.4(1996):488.

${ }^{173}$ Margold, Jane A. "Narratives of masculinity and transnational migration: Filipino workers in the Middle East." Bewitching women, pious men: Gender and body politics in Southeast Asia, eds. A. Ong and M.G. Peletz. (Berkeley: University of California Press, 1995).
} 
take over the domestic duties. Instead many women complain that their husbands spend their hard-earned money on excessive drinking or gambling, now that they have been freed from the duty of breadwinning for the family. ${ }^{174}$

In the conservative, devoutly Catholic Philippines, spousal cheating has become a major concern. As researcher Pei-Chia Lan documented in her conversation with three Filipina migrant workers in Taiwan, women often worry that their husbands will fill their loneliness with other women.

Helen: You remember Lisa? She went home for a vacation and came back again. She caught her husband with another woman. [Everybody sighs.]

Claudia: Many families are into troubles when one of them works abroad. Because the wife works abroad, she sends a lot of money to the husband. Every day is like his birthday. Then the man has a concubine and the woman has a relationship abroad. Because they feel lonely!!

Olivia: When the wife is not there, the husband finds himself so miserable and he thinks, "I earn less than my wife" so he finds another woman!

The problem has become so pervasive that the Filipino media has coined the term "Saudi Syndrome," describing the anxiety felt by migrant workers in the Middle East who worry that their wives may be cheating on them in the Philippines. ${ }^{175}$ It's widely held that husbands left behind are more likely to cheat than wives left behind, as explained by Olivia in the earlier conversation, who points out that the domesticated

\footnotetext{
${ }^{174}$ Lan, Maid or Madam 193.

${ }^{175}$ Fe R. Arcinas, Cynthia Banzon-Bautista and Randolf S. David, The odyssey of the Filipino migrant workers to the Gulf region. (Quezon City: University of the Philippines Press, 1986).
} 
husband feels inferior and miserable with an endangered masculinity as his wife has become the family's primary breadwinner.

Many Filipinas migrate abroad before they are married and once they have served their filial duty, return to the Philippines with hopes of getting married. For them, migration has been conceptualized as a form of population control. The export of women has been found repeatedly to result in better family planning through the postponement of marriage, while those who return overseas after marriage benefit from the interruption to the fertility patterns of married couples. ${ }^{176}$

However upon their return to the Philippines, many of these women struggle to find suitors, as Filipinas who have been overseas workers are less desirable as wives for Filipino men. Their stint in foreign, metropolis cities around the world leaves Filipino men assuming that they are too liberated and less likely to conform to rural lifestyles and the traditional norms of femininity, including the gendered division of labour. ${ }^{177}$ This phenomenon is particularly visible among Filipinas who have worked in Japan, often as hostesses, singers and dancers in bars and hotels, referred to as Japayuki. Both in Japan and the Philippines, these women are commonly maligned as prostitutes, an image that persists so strongly that all Filipinas who have worked overseas are subject to suspicion in the Philippines for being potentially associated with the sex industry. ${ }^{178}$

\footnotetext{
${ }^{176}$ Andrew Gonzalez, "Higher Education, Brain Drain and Overseas Employment in the Philippines: Towards a Differentiated Set of Solutions" Higher Education, 231(1992): 31.

${ }^{177}$ Lan, Maid or Madam 202.

${ }^{178}$ Nobue Suzuki, "Between two shores: Transnational projects and Filipina wives in/from Japan," Women's Studies International Forum 23.4(2000).
} 
Filipinas unable to find anyone willing to marry them often turn to the international market. The Philippines is a major source of mail-order brides, who are sent around the world to anyone capable of paying for them. Filipinas are considered ideal traditional wives, unlike Taiwanese and Western women who are perceived to have long been liberated from traditional gender roles. Those who purchase mail-order brides are often widowed or divorced, lower-class and not favoured by women in their own country, says Roland Tolentino in his study of the Filipino mail-order industry, and they attempt to "fulfill their nostalgia for a pre-feminist family romance by constructing an ideal domestic sphere sustained by the household labour of servile foreign wives."179 So they turn to mail-order brides, who are often stigmatized internationally as docile, subservient Oriental women or, in the Philippines, as greedy women willing to deceive foreign husbands in exchange for a passport to a better life. ${ }^{180}$ Often times, as Pei-Chia Lan points out in her analysis of the mail-order bride industry, these women are neither, but simply "active agents managing to improve their well-being within structural and ideological constraints."

Ironically for mail-order brides, the experience of overseas domestic work is often perceived as a positive qualification. Lan observed a group of Filipina domestic workers in Taiwan as they read and discussed an application for an international pen pal club, in which success often yields an international marriage. One of the women was embarrassed by the question that asked about her profession. "How did you answer this?

\footnotetext{
${ }^{179}$ Tolentino, 67-71.

${ }^{180}$ Elizabeth M. Holt, "Writing Filipina-Australian bodies: The discourse on Filipina brides," Philippine Sociological Review 44(1996).

${ }^{181}$ Lan, Maid or Madam 203.
} 
What's your profession?" she asked her friend. Another domestic worker replied bluntly and without hesitation, "It's okay to say caretaker or domestic helper. They like that because they are all old and they like people who can take care of them."182

Lan argues that the similarities between being caregivers and unpaid housewives is part of the "driving force" that pushes domestic workers into international marriages. ${ }^{183}$ To support this argument she points to the case of migrant domestic workers getting married to their bosses. In Taiwan, she observes, it is not uncommon for Taiwanese middle-aged, widowed or divorced men to propose to their migrant workers, often hired to care for their old or ill mothers. It's often perceived as an attempt to secure the same level of domestic servitude for free, and domestic workers weigh the security of an international marriage against their current salary before deciding whether to accept. ${ }^{184}$ Many female migrants who become spouses continue to work as domestic workers parttime, taking advantage of the fact that this informal job can be performed without knowing the local language or legitimate working papers. ${ }^{185}$

\footnotetext{
${ }^{182}$ Ibid., 203.

${ }^{183}$ Ibid.

${ }^{184}$ Ibid.

${ }^{185}$ Ibid.
} 


\section{Chapter 4: Brain Drain}

The Filipino experiment with the export of human capital has left theorists torn as to whether a country can actually lift itself out of poverty through migration alone, given that receiving countries, acting in their own interests, often exhibit preference for skilled or highly-educated migrants. In the Philippines, this preference has resulted in a statesanctioned brain drain, as migrating workers often include professional and skilled workers. In 1980, more than 36 per cent of overseas foreign workers were college graduates while an additional 13 per cent had completed some college. ${ }^{186}$ The brain drain is exacerbated by the fact that, once abroad, many of the migrants are placed in low- or semi-skilled employment, as the very professions that earned them deployment, such as medicine, are treated as non-transferable skills.

While the majority of those migrating out of the Philippines are unskilled, the staggering impacts of skilled worker migration on the Philippines must be considered. This category includes those with university degrees or extensive experience in a specific field. It ranges from highly-skilled specialists, to senior managers and physicians. ${ }^{187}$ In 2003, one-third of the Filipinos who left the country were considered professional or technical workers. ${ }^{188}$ Their migration, like that of their low-skilled counterparts, often

\footnotetext{
${ }^{186}$ Maruja M. B.Asis, "The Overseas Employment Program Policy," Philippine Labour Migration, eds. G. Battistella and A. Paganoni, (Quezon City, Philippines: Scalabrini Migration Centre, 1992).

${ }^{187}$ Organization for Economic Co-operation and Development (OECD). SOPEMI: Trends in International Migration: Continuous Reporting System on Migration, Annual report, 1997 (Paris: OECD, 1998) 21.

${ }^{188}$ Philippine Overseas Employment Administration 17 Feb. 2008, 15 Apr. 2008

$<$ http://www.poea.gov.ph/>
} 
encompasses a search for better opportunities for them and their families and hope for a better lifestyle. ${ }^{189}$

The numbers given above are estimates, as there exists little data that comprehensively demonstrates the extent to which the highly-skilled migrate from developing to developed nations. The lack of data, says academic Robyn Iredale, is due to the difficult nature of collecting such information and the "invisibility" of much of this migration as well as the unwillingness of both sending and receiving countries to acknowledge migration of the highly-skilled. ${ }^{190}$

But this data is sorely needed. When it comes to trying to attract highly- skilled and entrepreneurial immigrants, Australia, Canada and the United States have become competitors. In making their decision, potential migrants take each country's recruitment attempts into consideration, as well as rates of economic growth and opportunities for employment, particularly within their field of training.

The continued loss of skilled professionals in developing nations has gone largely unnoticed, allowing this brain drain to be advantageous to developed countries, and constituting what academic Vijay Naidu calls a form of "development aid from the developing to the developed countries." ${ }^{, 191}$ While the practice is not new, economic globalization and an increasing gap between sending and receiving countries have silenced any dialogue on the subject.

\footnotetext{
${ }^{189}$ Robyn Iredale, "Migration Policies for the Highly Skilled in the Asia-Pacific Region," International Migration Review, 34.3(2000):882.

${ }^{190}$ Ibid., 885.

${ }^{191}$ Vijay Naidu, panel discussion, at Workshop on Asia-Pacific Migration: Will the Financial Crisis Represent a Turning Point?, Australian National University, Canberra. 17-18 October 1998.
} 
When the subject does arise, it is often pointed out that brain drain cannot be considered a complete loss. The loss of highly-skilled professionals is not necessarily permanent or without benefits for the sending countries, as sometimes migrants return home with new skills, capital with which to invest and international networks. And almost always, migrants send back remittances that stimulate the economy.

The Philippines has felt both the benefits and disadvantages of skilled migration. The country is at great risk of extensive brain drain, given the country's obsession with migration and the high rates of university participation. The level of college attendance in the Philippines is comparable to most developed nations, besting advanced countries such as Israel, Japan, Sweden and Australia. ${ }^{192}$ In 1978, the country's population stood at 40 million people, with three-quarters of a million students enrolled in more than six hundred colleges and universities. In comparison, China with twenty times the population had only half a million students attending college. ${ }^{193}$

The Philippines has a long history of migratory professionals. ${ }^{194}$ In 1975 , just over 35,000 Filipino professionals left the country in search of work. Twenty-two years later, the Philippines had become one of the top sources in Asia for skilled professionals, exporting nearly 750,000 highly-skilled professionals in 1997 . The bulk of these professionals arrive in North America.

\footnotetext{
${ }^{192}$ UNESCO Statistical Yearbook 1968, cited in Education for National Development, Report of the presidential Commission to Survey Philippine Education, (Makati, Rizal, Philippines, December 1970) 31 .

${ }^{193}$ Daniel H. Perlman, "Higher Education in the Philippines: An Overview and Current Problems." Peabody Journal of Education, 55.2(1978): 119.

${ }^{194}$ Tujan, 3.
} 
Migration has the potential to drain a country of its brightest, most highlyeducated and most entrepreneurial citizens. And when it happens, as is commonly the case in the Philippines, it deprives the state of revenue and of the investment they made in educating and training these professionals. Throughout the $1960 \mathrm{~s}$, the Philippines ranked second, bested only by India, in the number of scientists and engineers migrating to the United States. ${ }^{195}$ The lack of engineers is often blamed for hampering the development of infrastructure across the Philippines. In health and education, the loss of professionals can seriously impact the supply and quality of essential services. "We feel the absence, especially the teachers - we cannot get teachers to stay in these rural areas," says Agnes Hortez, a rural development officer on the island of Palawan. "And most areas don't even have nurses - just one midwife for the whole region."

The loss of teachers is a story that's all too familiar to Carmelita Padaen. As the principal of an elementary school in a far-flung rural Filipino village, she's watched teachers rotate in and out of her school. "As soon as they get papers to go abroad, they leave. And then we don't have enough teachers. If we do get someone new, then we have to train them." The school is desperately lacking teachers - there are only six teachers for 254 students. "Just enough to have one for each class level. Nothing more," says Padaen.

But it is the migration of health professionals that is worrisome. While its not a new trend-the Philippines was the leading source of physicians and surgeons in the 1960s to the US - it has combined with the export-friendly policies of the Filipino

\footnotetext{
${ }^{195}$ Ibid.
} 
government to currently be happening in record numbers. ${ }^{196}$ "Over the last 10 years, they've had over 100,000 nurses go abroad," says Joanne Lazarus, a Canadian anthropologist who studies the effects of migration on the Filipino health-care system. "Because of a lack of staff, 1,000 hospitals have shut down in the Philippines in the past two years. In some places in [the southern island of]Mindanao, hospitals have not had an actual doctor or nurse working in 10 years. They've actually got midwives running the place."

For every 100 doctors trained in the Philippines, only 25 remain permanently. "We are investing more in the overdevelopment of Europe and petrodollar-rich Arab kingdoms," writes San Juan in his book Filipinos Everywhere, "than in our country where we are witnessing, in slow motion, the irreversible collapse of the health-care system." 197

The situation for nurses and physical therapists is even worse, says Mel Garcia, the executive secretary of the Alliance of Health Workers, a union that represents most of the government hospital workers in the country. ${ }^{198}$ In 1998, of the 130,000 nurses registered in the Philippines, 70,000 were employed abroad. ${ }^{199}$ Countries such as Ireland, Saudi Arabia and the United Kingdom are increasingly recruiting Filipinos to meet desperate shortages of nurses and physical therapists. Their willingness to take these jobs is rewarded with salaries several times better than the US $\$ 200$ the average Filipino nurse

\footnotetext{
${ }^{196}$ Ernesto Pernia, "The Question of Brain Drain from the Philippines," International Migration Review, 10.1(1976): 63 .

${ }^{197}$ San Juan, vi.

${ }^{198}$ Tujan, 3.

199 "More RP nurses are employed abroad," The Philippine Star. August 18, 1989:1
} 
makes in one month. Dr. Jojo Carabeo, president of the Health Alliance for Democracy, says that Filipino nurses often work in hospitals as trainees for three to six months and leave the country as soon as they have the experience needed to go abroad. ${ }^{200}$ They leave behind a hospital system perpetually staffed by nursing trainees and a country facing a severe shortage of nurses willing to stay in the country. The problem is compounded by the resulting lack of experienced nurses to teach incoming students and help alleviate the shortage. ${ }^{201}$

According to a study done six years ago on Manila hospital staff, 13 out of the 18 nurses who worked in the operating room at the Jose Reyes Memorial Hospital had pending visa applications to work abroad. At the Tondo Medical Centre, nurses often worked shifts of 16 to 24 hours, just to maintain the requisite number of nurses on duty at all times. They used to work eight-hour shifts, before the migration bug hit their staff hard. It was a similar situation at the San Lazaro Hospital, where an entire ward was staffed by three nurses - one of whom was charged with administration, leaving just two people to perform all of the nursing duties. ${ }^{202}$

The demand abroad for Filipino nurses is so high that it has given rise to a new phenomenon in the Philippines, where licensed doctors are taking further studies in nursing in order to be able to migrate abroad more easily. ${ }^{203}$ "Can you imagine," chuckles Randy Veloso, a retired banker in the Philippines, "a doctor taking a nursing course just to leave the country?" The practice has become so widespread that there are at least 45

\footnotetext{
${ }^{200}$ Ibid., 4.

${ }^{201}$ Gonzalez, 23.

${ }^{202}$ Tujan, 4.

${ }^{203}$ Ibid., 1 .
} 
schools in the Philippines that offer abbreviated courses specifically to doctors who want to become nurses. Those who manage health-care in the Philippines call the trend unsurprising, given that doctors in the Philippines receive only slightly more than the P10,000 (US\$200) a month that nurses make in government hospitals. While it varies, the pay is often lower in private hospitals and can drop as low as P5,000 (US\$100) per month. ${ }^{204}$ Lazarus has made this the focus of her research in the Philippines and has been astonished at how common nursing medics, as they are known, have become. "This year, they've got 5,000 doctors retraining to be nurses. Eighty per cent of all government physicians are either retraining right now, or have already done so."

The low pay of doctors is just part of the reason for nursing medics, she says. Nurses are much more in demand abroad than doctors, as Lazarus discovered when she analyzed who was recruiting Filipinos for health-care jobs abroad. She crunched data for one particular day in July and found that while there were 403 openings for doctors in 25 countries around the world, there were 43,000 posting for nurses on the same day. While Australia led the demand for doctors, the United States was the top recruiter of nurses with just under 20,000 jobs available. Doctors becoming nurses can then be understood as an inevitable result of this uneven demand, she says. "The doctors have jumped on the money train." They see it as their way into the United States.

As a result of the increased international demand for nurses, nursing schools have proliferated across the country. In 1999 there were 170 of them in the Philippines. A mere six years later, the number had almost tripled to 470 . "It's clear that they're doing it for migration, because less and less nurses are taking the Filipino board exam," says

\footnotetext{
${ }^{204}$ Ibid., 1 .
} 
Lazarus. The board exam is mandatory for any nurse who wants to practice in the Philippines.

The trend of nursing medics has created a drastic shortage of doctors in a healthcare system that was already understaffed. "Now it's so bad that the Ministry of Health is trying to decide whether they should ban any of the doctors from leaving the country," says Lazarus. What's worse is that the shortage shows no signs of improving. At the University of Philippines Manila (UP Manila), the most prestigious university in the country, applications to the medical school have fallen to record lows. "They were unable to fulfill its freshman quota in 2007," she says. "Meanwhile at the college of nursing, they've got 14,000 applications for 70 spots."

UP Manila refuses to accept nursing school applications from doctors that are retraining. "They don't want their school associated with nursing medics," says Lazarus. In her research, she found that there was often a stigma associated with doctors becoming nurses. Half of the doctors she interviewed didn't even tell their families that they were retraining. But others, she says, had families who were supportive. "For many families, it's just seen as somebody else going abroad," she explains. "Migration is part of the Philippines psyche."

What amounts to a blow for the health-care sector of the Philippines is not always a gain for the receiving countries. Many Filipino nurses, nursing aides and teachers work as domestic workers overseas, as the placement and other related fees to become a domestic worker are lower than those for a health-care professional. Other nurses find themselves unable to work in health-care when they do not have the funds to take, or do not pass, their licensure exams abroad. The case is similar with doctors, many of whom 
are unable to get licensed abroad. In Canada, many Filipino paediatricians and internists work as pulmonary aides and therapist assistants, while the US has more than its share of former doctors from the Philippines working as pharmacy aides. ${ }^{205}$

The root cause of skilled migration from the Philippines lies in the low salaries and poor working conditions that plague both the private and public sector, making it difficult for highly-skilled health professionals as well as scientists, engineers and academics to achieve a satisfactory lifestyle. Most professionals find themselves relying on additional sources of income to support their families, such as their spouse's money, inheritances or consulting on the side for multinationals and international agencies. ${ }^{206}$ The attraction to working overseas is then understandable, but does not lessen the problem of highly-trained manpower leaving the country.

Their realization of migration's potential for harm has the best of policy-makers struggling to come up with solutions. A simple remedy would be for the sending countries to ensure that they adequately provide career incentives for their best and brightest to stay, including appropriate pay, satisfactory working conditions and upward mobility. But for countries like the Philippines, saddled with an enormous foreign debt and tremendous pressure by the international financial institutions to liberalize their economies, there just aren't the funds available to enable such strategies.

Other strategists have coined the phrase, "train and retain" referring to the earlier mentioned suggestion of barring badly-needed professionals from leaving the country. ${ }^{207}$

\footnotetext{
${ }^{205}$ Ibid., 1 .

${ }^{206}$ Gonzalez, 26.

${ }^{207}$ Report of the Global Commission on International Migration, 25.
} 
This approach is widely acknowledged to be inconsistent with human rights, in that it restricts freedom of mobility for certain sectors of the population. It also counters the increasingly global tendencies of the market for labour and is very difficult to implement and regulate. If put into practice, highly-skilled migrants who do make it out of the country through illegal means would be discouraged from returning, believing that they might be penalized if they did.

A second solution calls for the receiving states to financially compensate the sending countries for their loss in labour and expertise. Critics have attacked this solution for being impractical, as professionals tend to work in more than one receiving country, begging the question as to which country should provide the compensation. It would be difficult to assess where the funds being paid out should be directed and a system would be needed to ensure that the compensation payments would actually be reinvested into training and retaining strategies.

Others have called for a code of conduct among receiving countries to regulate the migration of highly-skilled professionals. Yet there is little evidence demonstrating that these codes have any impact. Countries where an informal code has been put into place, such as Malawi with its burgeoning AIDS-affected population, continue to see their health-care professionals being lured away by recruitment campaigns from developed nations. $^{208}$

There has been some success in campaigns that call for foreign aid and investment to be redirected towards countries, and specific sectors within these countries, that have been hard hit by the loss of professionals through migration. For example, co-

${ }^{208}$ Ibid., 23. 
investment programmes seek to establish a cooperative relationship, whereby the receiving nations invest in the education and training of workers within the sending nation in an effort to create a mobile and global pool of professionals that can benefit either country. This is the aim behind the UK Department for International Development's investment in the healthcare capacity of India. ${ }^{209}$

Lastly strategists call on the receiving nations to better foresee and plan for their labour needs, so as not to rely as heavily on the professionals of the developing world. Better investment in their own citizens, combined with an improved focus on impending and projected gaps in the national labour market would lessen the recruitment pressures on the highly-skilled in developing nations. As stated in the 2005 Report of the Global Commission on International Migration, "It is irresponsible for the world's more prosperous states to ignore these responsibilities and then to look for a quick solution to their human resource problems through the active recruitment of professional personnel from developing regions. ${ }^{, 210}$

While these strategies may hold some promise, their application to the Philippines seems unlikely. Those who defend migration point out that many of the highly-skilled migrants who go abroad often return to the Philippines to retire, bringing back their skills and the money they earned. Others say that the remittances they send, often higher than other migrant groups because of the skilled nature of their work, more than compensates for any brain drain.

Others maintain that migration is sustaining the underdevelopment of the Philippines. As Ross Jeambey, a Peacecorps volunteer in the Philippines explains, "One

\footnotetext{
${ }^{209}$ Ibid., 26.

${ }^{210}$ Ibid.
} 
of our best teachers went to China to become a domestic helper. I begged her not to go she's our most qualified teacher, we can't lose her." She ended up leaving anyway, says Jeambey. "Think about the thousands of children she would have taught." 


\section{Chapter 5: Democratic Impacts}

In the quest to become developed, communities around the world embark on staggeringly different journeys. Some seek access to potable water as the first step, some pave the way for social freedoms while others enable development through technology.

Regardless of the path that they take, theorists believe that one of the key factors in achieving development is the creation of a burgeoning middle-class. It is they who will demand democracy and push for it to be continually upheld. It is the middle-class who will pay taxes to support the continued expansion of infrastructure. It is they who will interact with the state as both providers and receivers.

It's a formula that has worked before for the Philippines. In 1986, it was the middle-class, armed with dreams of a better Philippines, who marched for days in Manila's People's Power Movement. Their march culminated in the world's first bloodless revolution by deposing then-president Ferdinand Marcos, the once democratically-elected president who declared martial law, stifled opposition and the media, and killed his political rivals to stay in power. People's Power came together again in 2001 to drive out corrupt movie-actor president Joseph Estrada.

But the formula has stopped working as of late in the Philippines-and the explanation is simple. The country's middle-class now lives abroad, dreams of going abroad and is sustained by someone abroad. "That's what happens when your middleclass leaves," says Hannah Yao, a Filipina whose parents helped to depose Marcos but who now live in Canada. "There's no one there to fight for everyone, to care about things, to make things work from the inside." 
What's emerged is a country mired in a democracy that is more apparent on paper than a real practice. Rigged elections, coup attempts, insurgencies and division now characterize Filipino politics. $^{211}$ Elitism dominates. Since 1987 , two out of every three members of the House of Representatives belong to families who have held elective posts for at least two generations. They have been getting richer, with fewer and fewer representatives from the lower- and lower-middle classes. ${ }^{212}$ Migration, says David Wurfel, author of Filipino Politics: Development and Decay, is "draining the pool of leadership for reformist or even revolutionary politics. Of course it's less likely to drain the pool of revolutionary politics and more likely to drain the pool of reformists."

In 2006, a wide range of groups waged a coup to wrestle power from President Gloria Macapagal-Arroyo, who has headed the country since 2001. The attempted coup came as Filipinos celebrated 20 years of liberation from the reign of Marcos. Their attempts failed and in response, she declared a state of emergency, further plunging the country into crisis. ${ }^{213}$ The state of emergency lasted for three weeks, finally quelled by widespread opposition to the harsh measures. The Supreme Court would later rule that the official acts committed under the emergency proclamation were illegal.

The failed revolt, say scholars, are indicative of a deep malaise within Filipino politics. Filipinos are disillusioned with the notion of democracy. In the 22 years since

\footnotetext{
${ }^{211}$ Michael J. Montesano, "The Philippines in 2003: Troubles, None of Them New," Asian Survey, 44.1(2004):93.

${ }^{212}$ Sheila S. Coronel, Yvonne T. Chua, Luz Rimban, and Booma C. Cruz, The Rulemakers: How the Wealthy and Wellborn Dominate Congress (Quezon City: Philippine Center for Investigative Journalism, 2004).

${ }^{213}$ Sheila Coronel, "The Philippines in 2006: Democracy and Its Discontents," Asian Survey, XLVII $.1(2007): 175-182$.
} 
they took to the streets to demand democracy, it has yet manifest a more accountable government or a more equitable or prosperous society. Money and patronage continue to speak loudly in Filipino politics, as the power of Congress also remains in the hands of the political families who have ruled the Philippines for generations. ${ }^{214}$ The country has continued to be divided by a growing gap between the rich and poor, and, as Sheila Coronel notes in her exploration of Filipino politics, the middle-class, "once the agent of democratic reform, is increasingly impoverished and looking to overseas migration, rather than political action as the outlet for their frustrations." 215 It's more than an outlet, says Ross Jeambey, an American Peacecorps volunteer based in the region since 2005. "People think they can fix things by going abroad." And the government is more than happy to oblige their wishes as fostering emigration alleviates unemployment and defuses mass unrest. $^{216}$

What results is a divisive politics that is further driving the Philippines into instability and, in a circular pattern, increasingly driving its own citizens to seek migration abroad. The communist insurgency is gaining strength. The military express frustration that politicians have wreaked havoc on the country and dream of using their force to bring change to the country. Even the traditional political families, the elite for whom democracy has bestowed enormous benefits, are nervous. The entrenchment of electoral politics has turned into a popularity contest, with movie stars, news anchors and sports celebrities consistently winning national positions. ${ }^{217}$

\footnotetext{
${ }^{214}$ Ibid., 177.

${ }^{215}$ Ibid., 177.

${ }^{216}$ San Juan, 110.

${ }^{217}$ Coronel, 177.
} 
The vulnerability of overseas migrants, and the state's inability to protect them, has shed light on the diminished sovereignty of the Philippines and further turned the middle-class away from politics. The government's failure to protect Flor Contemplacion, as discussed earlier, and other Filipinos who have faced similar fates abroad is embarrassing to Filipinos and a reminder of the gross power imbalances between sending and receiving nations. ${ }^{218}$ The failure has also brought into the limelight the conundrum facing the Filipino government. It relies on the deployment of foreign workers around the world to generate foreign currency but lacks the strength to protect these workers should anything happen to them while abroad. The fate of overseas workers is not in the hands of the government of the Philippines, but instead left to receiving nations - a reality that has driven millions of Filipinos away from politics. As elucidated by Veronica Plandano, a domestic worker in Hong Kong:

We are called the living heroes or the new heroes. Yet why are we called 'heroes' when we are slaves in other countries?... Why does the government, instead of supporting our college graduates and youth and pushing them to strive in our country, actually allow them to leave the country yet without any sufficient protection as citizens? $?^{219}$

Migrant workers and their families are also turning away from the government because they can't understand how migration is helping the country in the long-term. As Bobby Gutierrez writes in Tinig Filipino, "In the latest survey, almost 6.5 million Filipinos are working in rich countries like Saudi Arabia, USA, Japan, Hong Kong, etc. And some of us are proud of it because we contribute a big amount of dollars in our

\footnotetext{
${ }^{218}$ Parrenas, Transgressing the Nation-State 1129-1154.

${ }^{219}$ Veronica Plandano, "Bayan, Kailan Pa?" Tinig Filipino, October 1995:60. Translated from Tagalog to English.
} 
national treasury every year. However, in my humble opinion, it is quite unfair because we spread our talent, knowledge and expertise to other countries instead of using them in our homeland. Perhaps it is one of the reasons why our country's economy is still way down below..."220 Gutierrez' comments demonstrate a glaring ignorance of the fact that much of the remittances sent back to the Philippines are used to pay down the $\$ 1.8$ billion in annual interest on loans from the World Bank and International Monetary Fund. ${ }^{221}$

Still the words of migrant workers and their families carry weight—often as much as the government themselves. As Parrenas writes, migrant workers' "sense of entitlement that they have gained from their position as the 'economic heroes' of the nation has reinforced their nationalist identity and empowered them to speak for and against their government.",222

Their harsh words have motivated some actions from the Filipino government. It aims to protect overseas workers through maintaining official contracts with receiving states. The Department of Labor and Employment (DOLE) monitors overseas contract workers through two agencies; the Philippines Overseas Employment Agency (POEA), responsible for keeping track of exiting workers, and the Overseas Workers Welfare Agency (OWWA), which services migrants in receiving nations. The OWWA offers pro bono legal assistance, counselling and insurance coverage as well as offers small loans for housing and start-up costs for small businesses. ${ }^{223}$ But the OWWA is subject to the

${ }^{220}$ Bobby Gutierrez, "Solving the Root Cause of Poverty," Tinig Filipino January 1995:31.

${ }^{221}$ Rosca, 522-27.

${ }^{222}$ Parrenas, Transgressing the Nation-State 1142.

${ }^{223}$ Ibid. 
laws of the jurisdictions in which it operates, greatly restricting their powers to help Filipinos. For example, an OWWA welfare centre in Saudi Arabia that was offering shelter to runaway maids was shut down because the Saudi government considered it to be foreign intervention into national affairs. ${ }^{224}$ In the same vein, the standards of employment stipulated by the POEA are virtually ignored in receiving countries and it is beyond the jurisdiction of the Filipino government to see to their enforcement. ${ }^{225}$

The Filipino government's ineffectiveness when it comes to protecting migrants can't always be blamed on a loss of jurisdiction. In 1990, 4,128 Filipino workers complained of being swindled during the recruitment process to work abroad, while 1,137 complained of being recruited by illegal operations. Despite the fact that these violations took place in the Philippines, within the government's jurisdiction, no action was taken and little has been done since to monitor the activities of recruitment agencies. ${ }^{226}$ "Leeches," is how Randy Veloso, a retired Filipino banker, describes the Filipino recruitment agencies. "They suck your blood." Rona Panizale, who used recruitment agencies to obtain her placement in the Netherlands agrees. "It's Filipinos taking advantage of these people. These organizations pocket a ton of money."

The recruitment agencies have their critics. "I haven't heard of one that is actually for the people," says Filipino-Canadian Aimee Beboso. Her family has lost thousands of dollars to recruitment agencies in their attempts to bring her cousin to Canada. "They're

\footnotetext{
${ }^{224}$ Mary Lou Alcid, "Legal and Organizational Support Mechanisms for Foreign Domestic Workers," The Trade in Domestic Workers: Causes, Mechanisms and Consequences of International Migration, eds. Noeleen Heyzer, Geertje Lycklama, A. Nijehold and Nedra Weerakoon, (London: Zed, 1994) 176.

${ }^{225}$ Christine Chin, In Service and Servitude: Foreign Female Domestic Workers and the Malaysian "Modernity" Project. (New York: Columbia University Press, 1998).

${ }^{226}$ Ibid., 195.
} 
usually there for the money. It's disheartening because they're taking advantage of their own people. They really squeeze money out of individuals that are looking for a better life."

The harsh words aren't how Heidi Santos would describe her business, Global Excellence Recruiting in Manila. "I'm here to help people realize their dreams," says Santos, herself a former domestic worker in Hong Kong. "We've sent people all over the world - from the U.S. to Italy to Canada to work, and they come back to visit me so happy - they're making money and taking care of their families because of us." She's quick to dismiss any allegations of wrong-doing by agencies, claiming that it's all about finding the right one. "There are agencies who just take people's money and don't place them. And when people complain about them, they dismantle the agency and put up one the next day in a different name." She's not like that, she says. She's one of the good ones. "After all, look at how many Filipinos are abroad. Some agencies are doing their job right."

The middle-class have also taken it upon themselves to attack the government for doing little to ease the flow of remittances, including the facilitation of low-cost money transfers from abroad to the Philippines. Even less has been done to encourage families to invest their remittances in household expenditures that could promote their welfare and employment gains, such as education, instead of non-productive consumption like TV's.

Those who seek to improve how the country is being run find little agreement on how to do it. Arroyo and her party have focused much of the debate on their proposal to move towards a unicameral, district-based parliamentary system, as opposed to the bicameral congress that currently exists. Arroyo argues that a parliamentary government 
is less prone to the paralyzing gridlocks between executive and legislative bodies that have hampered law and policy-making. As can be expected, the proposals have faced stiff opposition from the Senate, who stand to be eliminated if the proposal succeeds.

Arroyo was threatened with impeachment for the second time in 2006. She survived the first attempt in 2005, after her allies dismissed allegations of corruption and election fraud. The second attempt was based on the same charges as well as allegations of political killings perpetrated or tolerated by the military in the attempt to repress dissent against her government. ${ }^{227}$

The impeachment attempts have placed Arroyo and her forces on the offensive, says an Amnesty International report that documented intensified military operations in communist areas as well as a record-number of killings of left-leaning activists working for NGOs. At least 51 political killings took place in the first half of 2006, compared to the 66 that happened in all of 2005, a pattern condemned by Amnesty International. ${ }^{228}$ The report went on to ask whether the intensified operations against insurgents were not waged in response to national security threats, but instead efforts to demonstrate the close links between the government and the military while countering any potential future electoral success of left-leaning parties.

Opponents attribute the staying power of the unpopular Arroyo to the lack of a charismatic alternative, combined with public cynicism when it comes to politics. In December 2007, the People's Power Movement tried again to force out President Arroyo. "About 100 people showed up," says Jeambey. "They're trying to mimic the revolution

\footnotetext{
${ }^{227}$ "cPhilippines: Political Killings, Human Rights, and the Peace Process" Amnesty International, 15 Aug. 2006, 15 Apr. 2008 <http://web.amnesty.org/library/Index/ENGASA350062006>.

${ }^{228}$ Coronel, 179.
} 
of the 80 's, but people are apathetic." The apathy, he says, is to be expected from a population with eyes cast on foreign lands, oblivious to what's happening at home. "It's true all the way from the lower middle-class to the upper middle-class," agrees Wurfel. "Even among the leaders of the NGO movement, you'll find people transferring abroad."

There have been some positive developments in Filipino politics in the past year. Negotiations with the country's Muslim insurgents have been significantly less bloody and parties are hopeful that the 29-year insurgency might end soon. Despite sporadic outbursts of violence between these guerrillas and government troops, the negotiations have made substantial progress. Mediated by Malaysia, the talks have resulted in the settlement of nearly 80 per cent of the contentious issues and fighting has diminished significantly, allowing a degree of normalcy to return to some of the Muslim areas of the Philippines. ${ }^{229}$

Ironically, as migration is causing the middle-class of the Philippines to turn away from politics, the remittances that they send back constitute the bright spot of Filipino politics. In 2006 , the same year that turmoil in the government plagued the nation's politics, remittances from more than eight million overseas Filipinos exceeded $\$ 15$ billion, representing a 15 per cent increase from the year before. ${ }^{230}$ Strong economic growth, buoyed by an increasing number of remittances from abroad has characterized the Arroyo government, leading her supporters to point out that economics are her strength. Her opposition have been quick to retort that it is migrant workers that are the

\footnotetext{
${ }^{229}$ Carolyn O. Arguillas, "Dialogue Is the Only Option, Mindanao Leaders Tell GRP, MILF," Mindanews.com 11 Oct. 1I, 2006, 15 Apr. 2008

$<$ http://mindanews.com/index.php?optioncom_content\&taskview\&id1048\&Itemid75>

${ }^{230}$ David Llorito, "Philippine Economy on the Mend," Asia Times Online, 26 Oct. 2006, 15 Apr. 2008 $<$ http://www.atimes.com/Southeast_Asia/HJ26Ae01.html>
} 
country's heroes and without labour migration, the rate of unemployment would increase by 40 per cent and most likely send the country into political and economic chaos. ${ }^{231}$

Much of the strong economic growth has been confined to the middle- and upperclasses of Filipino society. A 2006 study, co-authored by the Asian Development Bank and the United Nations, named the Philippines among the region's worst off when it came to achieving the UN's Millennium Development Goals. The report cited the Philippines' failure to meet targets for several goals, including lowering child malnutrition, improving access to education, reducing carbon dioxide emissions, ensuring potable water access in urban areas and increasing forest cover. The country's progress was likened by the report as being on par with Bangladesh, Myanmar and Papua, New Guinea. $^{232}$ As Sheila Coronel writes in her analysis of Filipino politics,

"Those countries are hardly the company that Arroyo wants to keep, but the comparison is nonetheless an indicator of the paradoxical state of the Philippines in 2006. It is a country marked on the one hand by internecine rivalries among its elites, a restless military and a communist insurgency that feeds on mass poverty, and on the other by booming shopping malls, thriving call centers and a lively stock market. The Philippines has always been a country where paradoxes thrive." 233

As Filipinos have given up hope in organized political processes to bring about change, they have turned to outside structures, organizing and networking themselves through nongovernmental organizations (NGOs). Relative to countries around the world, the Filipino experience with NGOs came late in 1986, but came fiercely when it did. It

\footnotetext{
${ }^{231}$ Stephen Castles and Mark J. Miller, The Age of Migration: International Population Movements in the Modern World, $2^{\text {nd }}$ ed. New York: Guilford, 1998.

232 "Many Asian Countries Falling Short of MDG Targets, Joint Report Says," Asian Development Bank, October 2006, 15 Apr. 2008 <http://www.adb.org/Media/Articles/2006/10790-regional-MDGs/>

${ }^{233}$ Coronel, 182 .
} 
was civil society, composed of church groups, NGOs and labour and business associations that backed the People's Power Movement in deposing Marcos and sweeping Corazon Aquino to power. ${ }^{234}$ The expansive academic literature that then emerged on the role that civil society played in bringing democracy to the Philippines placed high hopes on NGOs as new actors in Filipino society. It was NGOs, theorists hoped, who could ensure an actual transition to democracy rather than the simple restoring of elite rule masquerading as liberal democracy.

Filipino NGOs have not disappointed, especially within the current OFW-crazed Philippines. Migration has enabled Filipinos to transcend the state to some extent and in doing so, they have enlisted the few organizations capable of echoing this transcendence. NGOs, many having evolved from their counter political status during Marcos' regime, play a prominent role in the lives of Filipinos, including migrants.

As mentioned earlier, workers from the Philippines are largely marginalized and remain vulnerable due to the combination of being both a migrant and a temporary worker. Despite this, there remains little political will on the part of receiving nations, and little ability on the part of the Philippines to enforce their social and legal rights. As pointed out by Sasha Courville and Nicola Piper in their discussion of the role of NGOs in the lives of Filipinos, "based on their class, gender and ethnicity, migrants are typically trapped between the diplomatic concerns of elite and intergovernmental politics at both ends of the migration chain. Alternative mechanisms therefore are needed." 235

\footnotetext{
${ }^{234}$ Karina Constantino-David, "From the Present Looking Back: A History of Philippine NGOs," Organizing for Democracy: NGOs, Civil Society and the Philippine State, eds. G. Sidney Silliman and L. G. Noble (Honolulu: University of Hawai'i Press, 1998).

${ }^{235}$ Sasha Courville and Nicola Piper. "Harnessing Hope through NGO Activism," Annals of the American Academy of Political and Social Science, 592(2004):47.
} 
Enter the NGOs. "They are very, very important," says Beboso, who volunteers with the Philippines Migrant Society of Canada, an organization that works to protect the rights of Filipino migrant workers in Canada. While migrants focus on meeting their basic needs and surviving, she says, NGOs look at the bigger picture for them. When her family first arrived in Canada, it was these organizations that helped them settle into their new home in Timmins, Ontario. "My mom thrived thanks to the Filipino community there. I can't imagine if it was just us, and nobody else." NGOs, says academic Arnel de Guzman, have been able to patch some of the "yawning gap between rhetoric and practice" when it comes to the Filipino government's consistent promises to protect the rights of migrant workers and their continued failure to do so. ${ }^{236}$

Their offerings of solutions that can cross borders are imperative for migrant workers, many of whom go virtually ignored in their receiving countries. Some, like those in Taiwan, find themselves caught in a country that has little prerogative to treat them humanely. There are an estimated 30,000 migrants in Taiwan, according to the Chinese Association of Human Rights. All of them are denied the freedom to organize and enforce their rights, a situation that is further complicated by the fact that Taiwan is not a member of the ILO, the UN and has no human rights commission. Any responsibility for the protection of migrant rights falls upon executive or judiciary bodies and NGOs. ${ }^{237}$

\footnotetext{
${ }^{236}$ quoted in Ibid., 195.

${ }^{237}$ Graziano Battistella, "The Human Rights of Migrant Workers: Agenda for NGOs," International Migration Review, 27.1(1993): 192.
} 
The NGO system to protect Filipino migrants seems to have evolved in tandem with the push to migrate. Unlike their counterparts around the world, Filipino NGOs are envied for their ability to work within a more open political system with relatively easy access to elite allies within the government structure. Much of this is due to the prominence of migration among middle-class families in the Philippines; as DeParle writes, "Woe now to the Filipino [politician] who appears not to have migrant welfare in mind. $" 238$

An example of this strength can be seen in MIGRANTE, the most successful of migrant-oriented NGOs from the Philippines in terms of grassroots support and transnational networks. It is staffed by activists who were once migrants, who work together with a tremendous amount of grassroots support to address the root cause of migration in the Philippines. While this is the focus of MIGRANTE's work at home in the Philippines, their offices abroad are vested in lobbying for better protection of migrant workers in receiving countries. Other NGOs, such as Kalayaan, mimic the international networks of migrants. Based in London, Kalayaan, caters predominantly to Filipinos and is linked with the European social service and workers' rights organization, Solidar. ${ }^{239}$ Here in Canada, several NGOs fall under the MIGRANTE banner and are active in helping Filipino migrants adapt to life in Canada. Danielle Norris, spokesperson from Citizenship and Immigration Canada speaks highly of the services these groups offer to new migrants. "A lot of the NGOs are in a good spot—-they've developed communities for live-in caregivers who have come in," she says. "If a Filipino woman

\footnotetext{
${ }^{238}$ Deparle, 4.

${ }^{239}$ Don Flynn and Eleonore Kofman, "Women, Trade and Migration," Gender and Development, 12.2 (2004):70.
} 
arrives as a live-in caregiver, they know where her community is, they're able to establish her, they're able to help her achieve her goals on that side to settle into society so that when she brings her family over, it's an easier transition."

One of these NGOs is the Ottawa Homemakers Association (OHMA). Regina Sosing Ferrar, motivated by her experiences as a caregiver, is a prominent member. Part of the service that they offer lies in their networking, she says. "Once we see a Filipino for the first time, we treat them like a long lost cousin." She pauses, adding that it's this cultural quirk that has allowed Filipinos to survive the distinction of being the most globalized workforce in the world.

The collective efforts of NGOs working to advance migrant welfare have had some large successes. In 1995, the Migrant Workers and Overseas Filipinos Act was passed, further protecting OFWs, and the International Convention of the Rights of All Migrants and Their Families (ICMR) was ratified. In 2004 they were instrumental in passing the Absentee Voting Bill, which enabled Filipinos working overseas the right to cast their vote in national elections for the first time. ${ }^{240}$

These groups have drawn tremendous strength from their linkages with international human rights organizations. Through efforts by the International Labour Organization and other United Nations branches to protect migrants, NGOs in the Philippines have been able to increase their reach, spread their message of collective hope and work internationally. ${ }^{241}$ Working together, NGOs and the ILO have launched a global campaign to boost the ratifications of the ICMR (which has yet to be signed by

\footnotetext{
${ }^{240}$ Courville and Piper, 49.

${ }^{241}$ Ibid., 50.
} 
any of the labour receiving countries), initiated the appointment of a UN Special Rapporteur on the Human Rights of Migrants in 1999 and oversaw the official launching of International Migrants Day on December 18 by the United Nations in $2000{ }^{242}$

These NGOs report that through consciousness-raising, or the sharing of their own stories and experiences as workers abroad, migrants begin the journey to empowerment. In understanding that the emotions of being separated from their families and working in countries with unfamiliar languages and cultures are shared experiences, the possibilities for change emerge - as elucidated by the director of a migrant worker NGO called Hope Migrants' Center:

We call the Center "Hope" because we try to give the workers a sense of hope amidst the misery and sufferings of their working conditions. Their hope for a more just and equitable working conditions lies in their courage to stand up for their human dignity and rights. ${ }^{243}$

Many of these NGOs fell into advocacy unwittingly. Most started by offering services to migrants, specializing in immediate crisis relief. The OHMA began by offering seminars with immigration officers and labour law experts to help caregivers understand their rights. They organized food nights, dances and field trips to Montreal and sugar shacks in the countryside. "It's important for our sanity," says Ferrar. "It also helps our member adjust to Canadian culture." As time went on and patterns began to emerge, they began to engage in advocacy and empowerment programs. Some of this shift in mission, says Courville and Piper, can be attributed to changes within the migration process itself, as the workers began to make prolonged stays abroad and

\footnotetext{
${ }^{242}$ P.A. Taran, "Human rights of migrants: Challenges of the new decade" International Migration. 38.6(2000).

${ }^{243}$ quoted in Courville and Piper, p. 51.
} 
demand different actions from NGOs, particularly concerning the protection of their rights. From rights advocacy came the search for solutions that tackled the root causes of migration, leading eventually to today's dominant philosophy among NGOs that advocacy must be in part the provision of social and legal services and in part the mobilization of migrant communities based on their economic and political strengths. ${ }^{244}$ Now the OHMA has been rolled into the Philippine Migrant Society of Canada, whose overall focus is on migrant rights and advocacy. While there are migrant workers and others who welcome the change, some like Ferrar don't agree. "They should stay focused on caregivers and the things that are beneficial to caregivers. Caregivers need to know how their degrees can be accepted here, what is life after the caregiver program, those things" she says. "Human rights has is beauty of its own, but it's a big enormous task." Other NGOs have shifted their interest to reintegration savings programs, discussed later on in this chapter, which encourage migrant workers to save their capital and invest in small businesses when they return home to the Philippines. The hope is that savings programs in all overseas communities could help to end the vicious cycle of circular migration by using their wages to develop a vibrant local economy in the Philippines.

These NGOs are limited in what they can achieve and much of their achievements depend on their transnational linkages. The importance of this was highlighted when, egged on by Filipino NGOs, Filipino domestic workers across Asia began to make headway in demanding their rights and raising their salary expectations - and were quickly replaced by Indonesians. ${ }^{245}$

\footnotetext{
${ }^{244}$ Ibid., 53.

${ }^{245}$ Battistella, 194.
} 
Despite the great number of groups and the strength of Filipino NGOs focused on migrant welfare, there continues to be some friction and conflict between the Filipino government and NGO relations when it comes to labour migration. ${ }^{246}$ And like their counterparts around the world, Filipino NGOs cite a lack of resources, funding, training and access to information as limiting factors. ${ }^{247}$

The prominence of NGOs in the Philippines has shifted the discussions around migration significantly, says Chiho Ogaya, who has extensively studied the discourses that define the lives of Filipina migrants. In order for NGOs to accomplish their goals, they must present migration as a "social problem" that needs to be remedied. This discourse contrasts sharply with government efforts to paint overseas foreign workers as "modern heroes." Ogaya writes that NGOs find a middle ground between both views, arguing that "overseas employment is economically necessary, but socially unnecessary and that the government is not fulfilling its responsibility as it is failing to create domestic job opportunities."248

Like the transnational NGOs that aim to protect the rights of migrant workers, overseas workers have developed relationships that transcend the states of their home and receiving countries. As they are no more than partial citizens overseas, Filipinos continue to regard the Philippines as "home" and the country continues to retain their

\footnotetext{
${ }^{246}$ May-An C. Villalba, "Protecting Migrant Workers Rights: Government-NGO conflict and cooperation." Philippine Democracy Agency, Vol. 2. eds. Marlon A. Wui and Ma. Glenda S. Lopez. (Quezon City: The Philippines: Third World Studies Centre, 1997).

${ }^{247}$ Marina Tzvetkova, "NGO Responses to Trafficking in Women," Gender and Development, 10.1(2002): 60-68.

${ }^{248}$ Chiho Ogaya, "Social Discourses on Filipino Women Migrants," Feminist Review 77(2004): 180.
} 
nationalistic loyalties. ${ }^{249}$ But simultaneously, they create a global community to sustain them, perceiving themselves part of an international community or an "imagined community." 250 Their community is based on an understanding of their presence in various countries around the world and bonded by their shared experiences.

Exemplifying this is Tinig Filipino. The magazine is run exclusively by a Filipina editor, Linda Layosa, formerly a domestic worker in Hong Kong. She began writing for Tinig Filipino when it was in its nascent stages. One year later, the owners turned to her for help with their lagging sales.

Layosa restructured the magazine's format, shifting the reliance from staff writers to an open invitation to Filipino migrants and their families to submit written pieces, from articles to poetry. The restructuring struck a chord with migrant workers' desperate need to address their experiences and share in social issues. Tinig Filipino often has a backlog of submissions. ${ }^{251}$

Parrenas, in her content analysis of Tinig Filipino over a period of 17 months, found that the most regularly addressed issue was transnational family life-particularly the difficulty of raising children from a distance. Work troubles, hassles with employers and government regulatory agencies and the trials and tribulations of love also figured prominently. As Parrenas writes, "I often felt as though I was listening to a conversation among migrant Filipino domestic workers, as the magazine regularly features reader

\footnotetext{
${ }^{249}$ Parrenas, Transgressing the Nation-State.

${ }^{250}$ Benedict Anderson, Imagined Communities: Reflections on the Origin and Spread of Nationalism (New York: Verso, 1983).

${ }^{251}$ Parrenas, Transgressing the Nation-State 1132.
} 
responses to previously published articles." ${ }^{252}$ Continuous debates that punctuated her analysis included whether it was considered abuse to leave behind children in order to migrate, with most readers saying it was, and an ongoing consensus that underemployment is an agonizing experience. ${ }^{253}$

Their imagined community is multinational, a needed characteristic given that families in the Philippines are often multinational. For example, Ruth Mercado works in Rome, her oldest sister works as a barmaid in Switzerland, her brother drives a tricycle in Manila while her other sister looks after the elderly in Saudi Arabia. Her parents live at home in the Philippines, networking with their children and depending on remittances from three different countries. ${ }^{254}$

Feature columns in Tinig Filipino include "Life in Italy," "Life in Saudi" and "Life in Singapore." 255 Through the sharing of experiences, the magazine fosters the realization that despite differences in geography, legality, politics and economics, the fundamental narrative of migrating for work is the same. The realization sets the stage for bonds that span continents, further contributing to an imagined community.

The strength of this imagined community and its ability to resonate with Filipinos who are absent citizens from their home country and partial citizens in their receiving nations, is epitomized through Filipinos' often ambivalent visits home. A mother who has spent four years working in Hong Kong and is excited to go "home for good" to her husband and children asks, "but why...is it hard now to leave this land of milk and

\footnotetext{
${ }^{252}$ Ibid.

${ }^{253}$ Ibid.

${ }^{254}$ Parrenas, Transgressing the Nation-State 1144.

${ }^{255}$ Parrenas, Transgressing the Nation-State 1151
} 
honey? Am I one of those who fear to go back to our country for good?"256 Another domestic worker, Betty Atiwa, echoes her sentiment, saying "For me, going back home is both pleasant and depressing. Pleasant in the sense that that I could see and live in my beloved country and be with my family again. Depressing because I will see poverty again." 257 It's a catch 22-as returning home brings to them to the very situations they had hoped to escape through migration.

Along with showcasing the shared experiences of Filipino migrants around the world, Tinig Filipino also attempts to publish relevant laws and policies of various countries, such as standardized contract changes. In the past, it has also published a listing entitled "Seeking Help?" that lists various community organizations offering help to migrant workers. In presenting their readers an alternative to the Filipino government's OWWA, Tinig Filipino acknowledges the role it plays in creating a global community and providing for this community beyond the nation-state. ${ }^{258}$

Here in Ottawa, Ferrar attempts to replicate the success of Tinig Filipino on a local level, with her weekly radio show and a bi-monthly newsletter that she describes as a "bridge between Canada and the Philippines." Her radio show, also called Tinig Filipino and broadcast for the past seven years on the Carleton University radio station, features headlines from the Philippines as well as events happening in the local Filipino community. Prominent Filipinos as well as members of the community-at-large, ranging from the federal minister of the environment, John Baird and Ottawa mayor Larry O'Brien have also appeared on the show. "Filipinos are very invisible in the

\footnotetext{
${ }^{256}$ Bing Cerdenola Villaruz, "Should I Go or Should I Stay?" Tinig Filipino, October 1995:62.

${ }^{257}$ Ibid, 62.

${ }^{258}$ Parrenas, Transgressing the Nation State 1150.
} 
community," she says when asked why she created the show. "We are strong, we have lots of contributions to society, but we are not as recognized as other communities. This show is a venue to unite our community and gain recognition."

In October 2008, delegates from around the world will gather in the Philippines for the Global Forum on Migration and Development. At the heart of their conference will be the question that has been asked time and again by Filipinos abroad and at home: Is migration the solution to global poverty?

Traditionally migration has been conceived as an action that negatively affects development—but as the remittances that migrants send home continue to grow exponentially, proponents have shifted the debate to argue that migration and migrants can actually enhance a country's development. "Mother's milk for poor countries," one Asian paper called remittances when they first started to surpass the world's foreign aid budget. $^{259}$

The shifting recognition is good for receiving countries. In Canada there is a movement to consider the remittances migrants send home as foreign aid. In doing so, Canada would reach its target of contributing 0.7 per cent of its GDP to foreign aid. ${ }^{260}$

The comparison between remittances and official development assistance (ODA) is often evoked, despite the fact that the characteristics, mode of operation, and role that each play on the international stage differ substantially. While remittances are private transfers between individuals, ODA flows between governments. ODA is often

\footnotetext{
${ }^{259}$ Devesh Kapur and John McHale, “Migration's New Payoff,” Foreign Policy, 139(2003):49.

${ }^{260}$ Personal communication with John Schram, former CIDA ambassador and professor at the Norman Patterson School of International Affairs.
} 
transferred on the basis of need and flows from rich to poor countries, while remittances flow to both rich and poor countries, often indiscriminate of need. Case in point: In 2004, France, Spain, the United Kingdom, Belgium, Portugal and the US were among the top recipients of remittances from around the world. ${ }^{261}$ Only a few of the world's least developed countries are in the top 20 remittance recipient countries, a fundamental hindrance to the unleashing of development through remittances alone. ${ }^{262}$

Still remittances have many advantages as compared to ODA. They are a more stable source of income, as opposed to ODA which changes with the whims of the donating government and are often subject to the conditions of international financial institutions. Remittances are insulated from the speculative behaviour of private investors and money managers. ${ }^{263}$ They feed directly into households, with the only intermediary being a formal or informal money transfer agency. The development enabled through remittances depends on how the funds are used; fundamentally a choice between consumption or investment, or a bit of both. The decision as to how to use remittances rests entirely on the receiver, while ODA is a bilateral or multilateral transfer of funds to the government of another country and its terms and conditions of use is negotiated between governments.

ODA does have some advantages. While remittances are fairly stable cash flows, the amount being sent is variable, subject to many conditions. The number of workers in a receiving country, the earnings of the worker, the percentage of earnings that they are

\footnotetext{
${ }^{261}$ Bimal Ghosh, Migrants' Remittances and Development: Myths, Rhetoric and Realities (International Organization for Migration Geneva, Switzerland, Den Haag: the Hague Process on Refugees and Migration, 2006) 25.

${ }^{262}$ Ibid., 25.

${ }^{263}$ Kapur and McHale, 50.
} 
able to save and the percentage that they are able to remit all influence what comes back to a sending country. ${ }^{264}$ The agencies that transfer remittances from one country to another, whether formal and informal, can absorb up to 10 to 20 per cent of the principal. $^{265}$

Remittances are also incredibly volatile, changing rapidly with the world economy. "Filipinos are being really hurt by the drop in US currency," says Alice Rotan, a foreign aid worker based in the Philippines. "When I came here, just two years ago, one US dollar was worth 52 pesos. Now it's 40 pesos to a dollar." The plunging US economy has had a strong impact on remittances and critics worry that the worst is still to come. "A labour-exporting country such as the Philippines," writes Glenis C. Balangue for the Filipino think-tank IBON, "is bound to suffer the consequences of over-dependence on labour export as labour markets constrict due to the global economic crisis." 266

Development theorists have debated voraciously about what sending countries should be doing with remittances. Some economists argue that they should be left alone, as they are a private gift between parties. Others argue that migrants' income, or at the very least, the remittances they send home, should be taxed. ${ }^{267}$ Repeated attempts by the government of the Philippines to cash in on the money being earned by migrants have failed, whether it be the allowance for overseas workers to spend up to US\$2,000 in tax-

\footnotetext{
${ }^{264}$ M.G. Quibria, “Migrant Workers and Remittances: Issues for Asian Developing Countries," Asian Development Review, 4.1(1986):90.

${ }^{265}$ World Bank, Global Economic Prospects: Economic Implications of Remittances and Migration, 2006. (Washington, D. C: World Bank, 2005).

${ }^{266}$ Balangue, 7 .

${ }^{267}$ Ghosh, 44.
} 
free stores upon their return home or requirements that migrants remit a minimum percentage of their earnings through the state-owned banking channel. ${ }^{268}$

Regardless of the state's interference, theorists say, remittances have the potential to unleash enviable development on a country. They are community-focused, relying neither on socialism or capitalism. They are self-motivated. They are sustainable, grassroots development that often puts money exactly where it needs to be-in the households of developing nations. Remittances don't require any costly bureaucracy and the money stands little chance of falling into the hands of corrupt government officials.

Remittances are often first spent on basic subsistence needs and better housing, contributing to the welfare of the family and raising the family's standard of living. In the Philippines, research has found that remittances directly fuel human capital development, through increased spending on education, more schooling for children and reduced child labour. ${ }^{269}$ Households have been found to consume both necessary and discretionary items, such as debt repayment and the purchase of housing and land. ${ }^{270}$ Remittances are often likened to income and risk insurance, allowing the household to work towards prosperity. ${ }^{271}$ A steady stream of remittances can improve the credit rating of a household, providing access to loans from financial institutions. Families connected to overseas contract workers were found to increase their level of investment in property from US $\$ 550$ before the migration to US $\$ 2,750$ after the migration. The household

\footnotetext{
${ }^{268}$ M.I Abella, "Labour Migration from South and South-East Asia: Some Policy Issues" International Labour Review, 123.4(1984):491-506.

${ }^{269}$ Ghosh, 52.

${ }^{270}$ Stahl and Arnold, 904.

${ }^{271}$ Ghosh, 52.
} 
personal savings increased from US\$140 to US\$2,100 and the monthly expenditure on education jumped from US\$26 to US\$48. One-third of migrant workers increased the amount that they spend on personal effects such as jewellery and watches. Sixty percent spend more on household appliances, such as new stoves, refrigerators and washing machines. Thirty-five per cent bought TV's, cassettes and stereos. ${ }^{272}$ But the development enabled through remittances often depends on who receives the money. Men tend to use remittances to purchase consumer items like televisions and cars, while women spend the money on health-care, food and schooling. ${ }^{273}$

At the community level, remittances are used to build modern housing, upgrade technology for farm production and serve as capital to grow income-generating small business enterprises. There is a long tradition of remittances being pooled by migrants abroad and transferred home to build schools, medical facilities and community centres, thereby enacting small-scale community development. ${ }^{274}$

These findings echo studies that say households linked to overseas workers save a significant portion of their earnings, but do not invest these savings in productive activities. ${ }^{275}$ Governments, private businesses and NGOs have been working to change this pattern through the promotion of economic reintegration strategies, mentioned earlier, aimed at helping migrants generate income through careful investment of their savings, including using them to start up small businesses in the Philippines. The

\footnotetext{
${ }^{272}$ Stahl and Arnold, 911.

${ }^{273}$ DFID/World Bank. International Conference on Migrant Remittances: Report and Conclusions' (London, 2003) 9.

${ }^{274}$ Ghosh, 53.

${ }^{275}$ Stahl and Arnold, 91 I.
} 
strategy, touted as a solution to the circular migration from the country, has been met with mixed reviews.

Reintegration programs work primarily with migrant women, training them overseas how to budget, invest and save money as well as how to facilitate the creation of savings groups and credit cooperatives. The migrant women are put in touch with organizations in the Philippines who suggest suitable investment opportunities. Some women write business plans while others seek out small and medium enterprises where migrant women could become owners and managers. According to Lalen Valesco, a staff member at Hong Kong NGO that is active in offering these training programs, the main impediment in getting these programs underway is the psychological barriers that migrant women have when it comes to holding back some of their earnings rather than sending it all back to their families. ${ }^{276}$

The poster girl for reintegration programs is Elsa Belarmino, formerly a migrant worker in Taiwan and now a successful entrepreneur in the Philippines. She was one of the first members of the reintegration program for migrant workers in Taiwan.

After graduating from university with a degree in Food and Nutrition, Belarmino was unable to find a decent job in the Philippines, instead spending years working for minimum wage at a Chinese fast-food chain. At the age of 25 , her family mortgaged their small piece of land to pay for her placement fee and she began life as a domestic worker in Taiwan.

"I hated life in Taiwan - I had to work so hard, usually 15 hours a day, with no time off," she says. Her employer had a fondness for late-night mahjong parties, forcing

${ }^{276}$ Kathleen Weekley, "Saving pennies for the State: A new role for Filipino migrant workers?" Journal of Contemporary Asia 01-04 Aug 2004. 1. 
Belarmino to wait on them until the early hours of the morning. The next morning she would be expected to rise early to do the laundry and prepare breakfast for the children of her employer. Her second placement was a better experience, her employer allowing her to take holidays and time off to attend church.

It was at church that she became acquainted with the Hope Workers' Centre reintegration program. After years of saving and a mere few months before her contract in Taiwan was up for renewal, Belarmino's sister informed her about the auction of a rice mill in her home province. "I knew right away that I needed to buy the mill. That was where my future was, not in Taiwan," says Belarmino. She was short of the capital needed to buy the mill and proposed the investment to her savings group. They declined, but she soon found other migrant workers willing to invest.

Today Belarmino works again in the Philippines, this time managing the mill. The NGO that introduced her to the idea of reintegration savings is still involved, now helping her with environmental scanning and feasibility studies. In its formative stages, the mill is breaking even and Belarmino is hoping to turn a profit in the coming years. "I'm home, I have a job and I can support my family," she says enthusiastically, stooping to bend and touch her land. "This is what every migrant worker should be working towards," she says, dragging her fingers through the mineral-rich dirt. She's become an enthusiastic advocate for migrant workers-come-entrepreneurs and shares her story time and again to encourage other migrant workers to end the pattern of migration by successful reintegrating into the Philippines.

Despite its success stories, reintegration strategies have been met with much criticism on the grounds that the strategy does not challenge the economic system that 
forces cross-border migration in the first place. They argue that teaching migrants to become entrepreneurs simply indoctrinates migrants deeper into the capitalist system that drives contemporary economic migration. ${ }^{277}$ The programs have been attacked for downloading responsibilities by suggesting individualist solutions to structural problems, creating self-motivating stakeholders who are ultimately the only ones responsible for their failures. Others have pointed out that the current zeal for reintegration programs undermines the global campaign for the protection of migrant rights by shifting focus to the individual and away from collective rights.

These criticisms emerge when the members of reintegration programs encounter difficulties, says Kathleen Weekley in her study of the successes and failures of reintegration programs. As one migrant worker told her in Hong Kong, "I set up my sarisari store[convenience store] but you know, in the barrio[neighbourhood], your neighbour will ask "can I borrow the bawang [garlic]?" If you don't agree to that, then you'll be an outcast in the barrio. And you know, there are so many migrant workers in our barrio and suddenly there are four or five sari-sari stores ... So, I'm here again [in Hong Kong] and I will save again Peso400,000 (US\$10,000), but I don't know where to invest. This time, I will listen attentively to the training!" Another woman Weekley encountered had saved enough to buy three hectares of land in the Philippines, which she used to plant onions, garlic and a few other vegetables to sell. One year later, she returned to Hong Kong to work. When asked about the land she replied that she had had to sell two hectares and kept one for family consumption, and that it was nearly impossible to sell garlic as "our

\footnotetext{
${ }^{277}$ Weekley, 1.
} 
garlic was too small. The garlic from Taiwan is big and cheap and ours is small and expensive. Now what would you buy? Big and cheap!... So, I can't go home."278

Despite these shortcomings, some continue to see the merits of reintegration strategies. Some NGOs are lobbying the Filipino government to echo the tax breaks and infrastructure support they offer to foreign companies in export-processing zones to migrants wanting to invest their savings in the Philippines.

Reintegration strategies aside, there still exists little evidence of remittances stimulating economic growth in the Philippines. As Beboso points out, "if [migration] had been so beneficial to the country, why do people keep leaving? The whole idea of migrant labour or opening borders to those in the developing world is to eradicate poverty, but it hasn't changed." Remittances have not been linked, in any convincing way, to sustained economic growth within a country, nor have they been shown to be a catalyst for economic growth. An OECD study of the impacts of remittances concluded that despite the benefits, including acting as welfare safety nets for those in the home country and alleviating poverty in the short-term, remittances "cannot create the right conditions for genuine development and are often criticized for their low impact on the structural causes of poverty. ${ }^{279}$

The OECD's assessment of remittances reflects their perils - they have been found to lead to flamboyant consumption in some households as well as add pressure to a country's import bill through increased demand for imported luxury goods.

Overdependence on remittances also makes economies vulnerable to changes in

\footnotetext{
${ }^{278}$ quoted in Weekley, 1.

${ }^{279} \mathrm{~F}$. Gubert, "Migrant remittances and their impact on development in the home economies: The case of Africa" Migration, Remittances and Development (Paris: OECD, 2005).
} 
remittances, should there be a sudden decline in the economies of the receiving countries. Some economists have purported that, in the long run, remittances increase a country's dependency on receiving nations, play a role in creating economic and political instability and distort development. ${ }^{280}$ "If anything, the Philippines in the 70s and 80 s was one of the better economies," says Beboso. "Now it's dwindling—its debt has increased, so basically now we're just putting stopgaps in certain things. Migration is a band-aid solution for everything else and it's compensating for the fact that we no longer have industries and our resources have been ransacked."

Others point to the dearth of evidence that remittances are ever used productively. In their study examining how remittances are spent, Castles and Kosack found that they are used more for consumption than enterprises, concluding that they were consistently an unlikely source of development. ${ }^{281}$ In 1982 , the United Nations took the stance that remittances "... generally have failed to contribute to development in the sending countries and have actually had a number of negative side effects...Typically little or none of the migrants' savings has been invested in capital-generating activities." ${ }^{282}$ Their stance came from the consistent research that found that remittances, while helpful, had done little to encourage long term development in the Global South. What remittances had done, according to academics Smart, Teodosio and Jimenez, was foster dependency. While remittance "pay levels are high relative to the Philippines, savings and asset

\footnotetext{
${ }^{280}$ Charles B. Keely and Bao Nga Tran, "Remittances from Labour Migration: Evaluations, Performance and Implications." International Migration Review, 23.3(1989):500.

${ }^{281}$ S. Castles and G. Kosack, Immigrant Workers and Class Structure in Western Europe (London: Oxford University Press, 1973).

${ }^{282}$ United Nations. International Migration Policies and Programmes: A World Survey. (New York: United Nations, 1982):42.
} 
accumulation does not appear to be sufficient to set workers up as independent entrepreneurs and at the same time permit maintenance of a higher family standard of living," they write. "In fact, Middle East employment risks a vicious circle whereby workers return home on a seemingly permanent basis but because savings are soon consumed they find that they have to return overseas in order to meet lifestyle expectations. ${ }^{283}$

Roy Banteras' life exemplifies the cycle they describe. He was lucky once, he's quick to say, because he worked as a seafarer from 1976 until 2000 . The US\$1,900 he earned monthly went a long way in looking after his six children, who range in age from 15 to 27 years. Life on the ships was "sometimes good, sometimes bad," he says, adding "It's so hard to be so far from your family for so long." He worked a radio officer and was let go when the job became computerized. He now works as a cab driver in Manila, making $\$ 600$ a month if he works 80 to 90 hours a week. His family, accustomed to triple the income, are struggling to make ends meet. He's been trying desperately to get back on the ships, but applications are often limited to men under the age of 35 years. At 51 years old, he's starting to accept that he's unlikely to be offered another job abroad. His newest strategy is to spend the rest of his family's dwindling savings to send one of his children abroad. He's not picky about where they go or what they do and he's decided that he'll send away whichever one gets accepted first. "I know that its not the best solution, but I don't know what else to do. What would you do if you were me?" he asks, smiling sheepishly.

\footnotetext{
${ }^{283}$ John E. Smart, Virginia A. Teodosio and Carol J. Jimenez, "Skills and earnings: issues in the developmental impact on the Philippines of labour export," Asian Labour Migration: Pipeline to the Middle East, eds. F. Arnold and N. M. Shaw (Boulder, CO: Westview Press, 1986) 123.
} 
Other academics use stories like Banteras' to show that remittances yield benefits at both the grassroots and the national level. They argue that remittances act as a stimulus to indigenous industries and contribute immensely to the supply of investment capital available in sending countries. ${ }^{284}$ While many remittances do enter the Philippines via informal channels, a substantial proportion still arrive in the country via traditional banking channels, serving as a monetary base from which banks can expand their loan portfolios.

These theories often profess a narrow view of remittances, ignoring the flight of human capital that is needed to generate remittances in the first place. San Juan asks eloquently in his book Filipinos Everywhere, "are the opportunities of consuming images and experiences offered by the wages of indentured labour enough to compensate for the nullity of citizenship and the loss of intimacy and the support of family and community?"285 Theorists answer that it depends on many factors, most prominently being the selectivity of international migration. In essence they argue that the benefits of remittances being sent home by migrants must be weighed against how much capital, both human and financial, migrants are taking abroad with them. ${ }^{286}$ As migrants from the Philippines tend to be from the middle- to upper-classes of the socioeconomic hierarchy, there exists much potential for the flight of sorely-needed human capital from the

\footnotetext{
${ }^{284}$ Stahl and Arnold, 915.

${ }^{285}$ San Juan, 133.

${ }^{286}$ J. Edward Taylor, Joaquin Arango, Graeme Hugo, Ali Kouaouci, Douglas S. Massey and Adela Pellegrino, "International Migration and National Development," Population Index, 62.2(1996): 190.
} 
country. ${ }^{287}$ In this case, the loss of migrants works against any development being achieved through remittances, for instance by slowing scientific and technological development, leading to lower productivity and lower wages for workers. The loss of capital also tends to widen the gap between developed and developing nations by concentrating the skill and expertises in developed countries. ${ }^{288}$ After finishing a degree in nutrition, Aimee Beboso's cousin came to Canada to work in the LCP. She earned her citizenship in just under four years, then started work at Wendy's. "She's kind of stuck there," says Beboso. "But if you ask her, she's completely happy with her life. But to me, I'm like, well why move? Why move? Why even go to school if you're not going to use it? And then what kind of country are we leaving in the Philippines if we're picking up all of these professionals and then dumping them into another country - what's the future of the Philippines?"

The fact that is it mostly middle- to upper-class households who are receiving remittances suggests that rather than enacting development, remittances are increasing inequality in the Philippines, a country that already demonstrates one of the highest levels of inequality among Asian countries. ${ }^{289}$

The loss of capital is negated when migrants come home, says one Canadian working at the embassy in the Philippines, bringing with them "ideas, goods and capital" gleaned from their stints abroad. "Every Filipino doesn't want to leave the Philippines -

${ }^{287}$ Edita A. Tan and Dante B. Canlas. "Migrants' saving, remittance and labour supply behaviour: The Philippines case." To the Gulf and Back: Studies on the Economic Impact of Asian Labour Migration, ed. Rashid Amjad (Geneva: International Labour Office, 1989).

${ }^{288}$ Taylor et al., 192.

${ }^{289}$ World Bank, From Plan to Market: World Development Report 1996 (New York: Oxford University Press, 1996). 
it's just for money," he adds. Balikbayan returning to the Philippines for their retirement years have spawned an entire industry of luxury home builders, exclusive neighbourhoods and services catering to this moneyed class. The struggle of Filipinos to balance their loyalty to their home country but also achieve the best life possible for themselves and their family is illustrated by a conversation between two Filipino women, Duchess Villar and Felly Masson. Both women migrated to the United States more than 30 years ago and had returned home for a visit. When asked whether migration is a blessing or blight to the Philippines, they couldn't decide:

Villar: It's helping the country - it's the only way things are changing here. Masson: yeah, but the country is losing all of its best workers - its brain drain. You're an accountant, I'm a teacher - we could be here helping our country. Villar: But we come back. We're all planning to retire here. And we send so much money back to the country.

Masson: But where does the money go? To our corrupt government?

Villar: That hasn't changed. It was corrupt before we left and it's still corrupt. That's why we had to leave, to give our families something better than this.

Their words ring with the multiple responsibilities that weigh upon Filipino migrants. They must secure a good life for them and their families but they also feel an obligation to do what is best for their country. The current government's campaign to recognize OFWs as modern-day heroes can then be dissected as a clever promotion designed to put their worries to rest, as they are told daily in national discourse that their migration is the best thing they can do for their country. 
But as Villar and Masson acknowledge, along with millions of Filipinos around the world, things are not as simple as they seem. Migration thrusts Filipinos into the most vulnerable of living situations, tears apart families, drains the country of its highlyskilled and erodes the democratic process. Yet these challenges of migration aren't enough to dissuade Filipinos from migrating abroad. Johnny Romero, father of two and migrant hopeful, waited hours in a line that snaked around the Philippines Overseas Employment Administration building. He explains, "Life would be better if I could work overseas." He shrugged when asked to clarify, repeating his words firmly. "Just better." 


\section{Conclusion}

While migration has given Filipinos the chance to earn money, explore other parts of the world, and, in some cases, become citizens of another country, they bear tremendous social costs in doing so. They have complained of being placed in exploitative and vulnerable positions abroad in jobs that often require fewer skills than they actually possess.

While the majority leaving the Philippines are single, a growing number are migrating in order to financially support their children, choosing to provide care for someone's else's family to do so. Most of these Filipino parents are mothers, a trend that is changing traditional gender relations in this Asian country, but not without criticism of the women concerned.

It's not just domestic workers who are leaving the Philippines. The country's health-care system is desperately short-staffed due to the migration of health-care professionals while rural schools go without teachers. Even the politics of the country have been altered by migration - setting one's eyes on going abroad is now part of the culture, more than a determination to stay and try to reform their corruption-plagued government.

The Philippine government actively exports its citizens around the world to work, but doesn't have the jurisdiction to ensure that they are being adequately protected while abroad. Keeping migrant workers from being exploited ultimately falls in the hands of receiving countries like Canada, who benefit from the cheap labour at the expense of the development of the Philippines. Most receiving countries, including Canada, have regulations regarding the treatment of migrant workers, but often these are not strictly 
enforced. It is NGOs who have risen to the challenge of fighting for the legal and social rights of migrant workers; from organizing social activities to information seminars, these groups have proved crucial players in Filipino migration. Development theorists have questioned whether these social impacts on Filipinos and their country outweigh the economic benefits of this migration strategy; as workers abroad send home remittances to invest in the health care, education and upward mobility of their families. Little of it is invested back into the economy of the Philippines, causing a circular migration pattern whereby the children of OFWs often find themselves abroad working in similar jobs as their parents. The repetitive nature of this migration suggests that, overall, it is not the ideal development strategy but instead one that has come at a costly price to Filipinos and their culture. 
Interviews:

Abigail Yao, former domestic worker in Canada, now a Canadian citizen, Jan. 30, 2008.

Agnes Hortez, rural development officer for the island of Palawan, Feb. 8, 2008.

Aimee Beboso, Philippine Migrant Society of Canada, Jan. 16, 2008.

Alice Rotan, American PeaceCorps volunteer based in the Philippines, Jan. 30, 2008.

Alvin Ebona, son of an OFW, Feb. 8, 2008.

Annabelle Padua, sister of an OFW, Feb. 9, 2008.

Anonymous, Human Resources and Social Development Canada, Dec. 14, 2007.*

Anonymous, Human Resources and Social Development Canada, Dec. 14, 2007.*

Anonymous, IBON, Feb. 18, 2008*

Anonymous, MIGRANTE, Feb. 18, 2008.*

Anonymous, Department of Foreign Affairs and International Trade, Feb. 4. 2008.*

Barbara Clausen, former employer of a domestic worker, Jan. 16, 2008.

Carmelita Padaen, school principal, March 2, 2008.

Cathy Devera (and family), moving to Canada to work as a domestic worker, Jan. 31, 2008.

Christian Castro, sales representative for Kraft in the Philippines, Feb. 1, 2008.

Christian Lopez-Vito, OFW serving in the American Navy, Feb. 2, 2008.

Cibella Lightfoot, Australian aid worker in the Philippines, Feb. 7, 2008

Danielle Norris, spokesperson for Citizenship and Immigration Canada, April 8, 2008.

David Wurfel, professor emeritus at the University of Windsor and author of Filipino Politics: Development and Decay, April 14, 2008.

Denise Spitzer, Canada research chair in gender, migration and health, April 11, 2008.

Duchess Villar, Filipina living in the United States since 1972, Feb. 8, 2008.

\footnotetext{
* Each of these sources has requested to remain anonymous. Their identity has been shared with Prof. Barbara Freeman, the supervisor of this thesis.
} 
Elsa Belarmino, former OFW, Feb 27, 2008.

Emily Jane Salayon, OFW, Feb. 15, 2008.

Felly Masson, Filipina married to an American and living in the United States for more than 30 years, Feb. 8, 2008.

Gabriel Gonzales, Former OFW, Jan. 27, 2008

Glory Romero, wife of OFW hopeful, Jan. 24, 2008.

Hannah Yao, Filipino-Canadian, Jan. 30, 2008.

Heidi Santos, manager of Global Excellence Recruitment, March 6, 2008.

Ivy Castro, sales representative for Shell in the Philippines, Feb. 1, 2008.

Ivy Tamgga, soon-to-be OFW, Feb. 14, 2008.

Jessie Gasner, aid worker formerly based in the Philippines, Jan. 28, 2008.

Joanne Lazarus, anthropologist studying the Filipino health-care system, April 4, 2008.

Johnny Romero, OFW-hopeful, Jan. 24, 2008.

Jose Pelayo, OFW, March 8, 2008.

Joy Ann Guilermo, OFW, March 12, 2008.

Joy Madulid, former domestic worker in Canada, April 9, 2008

Kei Naito, Former aid worker in the Philippines, Jan. 16, 2008.

Lauren Greig, aid worker in the Philippines, Feb. 4, 2008.

Lina Galang, wife of a former seafarer, Feb. 15, 2008.

Linda Bogaert, anthropologist specializing in Filipino culture, Jan. 26, 2008.

Lorena Dumagues, domestic worker in Hong Kong. First interviewed her in April 2005 and again on April 1, 2008.

Mimi Celdran, principle of a school and former OFW who returned to care for her sick son, Feb. 10, 2008.

Nestor Pulin, wife moving to Canada to become a domestic worker, Jan. 31, 2008. 
Peter and Veronica Davison, Canadian couple who employ a Filipina domestic worker, Jan. 8, 2008.

Peter Matheson, retired supervisor of construction sites in Saudi Arabia, Feb. 2, 2008.

Randy Veloso, retired banker in the Philippines, Feb. 10, 2008.

Regina Sosing Ferrar, former domestic worker in Canada and now an advocate for the rights of caregivers, April 13, 2008.

Rhoda Banteras, school teacher in the Philippines, Feb. 20, 2008.

Rona Panizale (and family), daughter of an OFW who is moving to The Netherlands in a few months to work as a nanny, Feb. 13, 2008.

Ross Jeambey, American PeaceCorps volunteer based in the Philippines, Jan. 28, 2008.

Roy Banteras, former OFW, Feb. 12, 08

Vicky Manahan, domestic worker in Canada, Feb. 16, 2008 
Bibliography:

Abella, Manolo. "International Migration and Development." Philippine Labour Migration. Eds. Graziano Battistella and Anthony Paganoni. Quezon City, Philippines: Scalabrini Migration Centre, 1992. 22-40.

---. "Labour Migration from South and South-East Asia: Some Policy Issues" International Labour Review, 123.4(1984):491-506.

“About us." Migrante International. n.d. 29 Sept. 2007. <http://www.migrante.org/>

Addleton, J. "The impact of international migration on economic development in Pakistan." Asian Survey 24.5(1984):574-596.

Alcid, Mary Lou. "Legal and Organizational Support Mechanisms for Foreign Domestic Workers." The Trade in Domestic Workers: Causes, Mechanisms and Consequences of International Migration. Eds. Noeleen Heyzer, Geertje Lycklama, A. Nijehold and Nedra Weerakoon, London: Zed, 1994. 161-177.

Alegado, Dean Tiburcio. "The political economy of international labour migration from the Philippines." Diss., University of Hawaii, Manoa, 1992.

Anderson, Benedict. Imagined Communities: Reflections on the Origin and Spread of Nationalism. New York: Verso, 1983.

Arat-Koc, Sedef. "Immigration policies, migrant domestic workers and the definition of citizenship in Canada." Deconstructing a Nation: Immigration, Multiculturalism and Racism in 90s Canada Ed. Vic Satzewich, Halifax: Fernwood, 1992.

Arcinas, Fe R., Cynthia Banzon-Bautista, and Randolf S. David. The odyssey of the Filipino migrant workers to the Gulf region. Quezon City: University of the Philippines Press, 1986.

Arevalo, Nina Rea. “Inay, Pasko na Naman.” Tinig Filipino December 1994: 28.

Arguillas, Carolyn O., "Dialogue Is the Only Option, Mindanao Leaders Tell GRP, MILF." Mindanews.com 11 Oct. 2006, 15 Apr. 2008.

$<$ http://mindanews.com/index.php?optioncom_content\&taskview\&id 1048\&Itemi d75>

"Many Asian Countries Falling Short of MDG Targets, Joint Report Says," Asian Development Bank, October 2006, 15 Apr. 2008 http://www.adb.org/Media/Articles/2006/10790-regional-MDGs/>

Asis, Maruja M.B. “The Overseas Employment Program Policy."Philippine Labour 
Migration Eds. G. Battistella and A. Paganoni, (Quezon City, Philippines: Scalabrini Migration Centre, 1992) 68-112.

Athukorala, P. "International contract migration and the reintegration of return migrants: The experience of Sri Lanka." International Migration Review 24.2(1990):323-346.

Balangue, Glenis. “OFW Remittances: Lifeblood of the Economy?” IBON Facts \& Figures 29.1(2006):1-8.

Barber, Pauline Gardiner. "Locating Gendered Subjects in Vocabularies of Citizenship." Women, Migration and Citizenship,_Eds. Evangelia Tastsoglou and Alexandra Dobrowolsky. Hampshire: Ashgate Publishing Limited, 2006.

Bakan, Abigail, and Daiva Stasiulis. "Introduction" Not One of the Family, eds. A. Bakan and D. Stasiulis. Toronto: University of Toronto Press, 1997. 3-7.

--.. "Making the match: Domestic Placement Agencies and the Racialization of Women's Household Work" Journal of Women in Culture and Society, 20.21(1995):303-335.

Basch, Linda, Nina Glick-Schiller, and Christina Szanton Blanc. Nations Unbound: Transnational Projects, Postcolonial Predicaments and Deterritorialized NationStates. Langhorne, PA: Gordon and Breach Science, 1994.

Battistella, Graziano. "The Human Rights of Migrant Workers: Agenda for NGOs" International Migration Review 27.1(1993):191-201.

Bell Kaplan, Elaine. "I don't do no windows: Competition between the domestic worker and the housewife." Competition: A feminist taboo? Eds. V. Miner and H.E. Longino, New York: The Feminist Press, 1987.

Calliste, Agnes. "Canada's Immigration Policy and Domestics from the Caribbean: The Second Domestic Scheme. Race, Class, Gender: Bonds and Barriers." Socialist Studies/Etudes Socialistes. Nov. 51989.

"Canada: The new frontier for Filipino Mail-Order Brides." Status of Women Canada 29 Oct. 2003, 01 Dec.

2007.<http://www.swccfc.gc.ca/pubs/pubspr/0662653343/200011_0662653343_9 _e.html>

Castles, Stephen, and Mark J. Miller. The Age of Migration: International Population Movements in the Modern World. $2^{\text {nd }}$ ed. New York: Guilford Press, 1998.

Castles, S., and G. Kosack. Immigrant Workers and Class Structure in Western Europe. London: Oxford University Press, 1973. 
Catholic Institute for International Relations (CIIR). The Labour Trade: Filipino Migrant Workers Around the Globe. London: Catholic Institute for International Relations, 1987.

Catorce, Rodney. “My Dad is Away, So What?” Tinig Filipino , June 1995: 9.

Chin, Christine. In Service and Servitude: Foreign Female Domestic Workers and the Malaysian "Modernity" Project. New York: Columbia University Press, 1998.

Cobb-Clark, D., and M. Connolly. "A Worldwide Market for Skilled Migrants: Can Australia Compete?” International Migration Review 31.3(1997):670-693.

Constable, Nicole. "At Home but Not at Home: Filipina Narratives of Ambivalent Returns." Cultural Anthropology, 14.2(1999): 203-228.

Constantino-David, Karina. "From the Present Looking Back: A History of Philippine NGOs." Organizing for Democracy: NGOs, Civil Society and the Philippine State. Eds. G. Sidney Silliman and L. G. Noble. Honolulu: University of Hawai'i Press, 1998.

Coronel, Sheila S. "The Philippines in 2006: Democracy and Its Discontents" Asian Survey XLVII-1(2007):175-182.

Coronel, Sheila S., Yvonne T. Chua, Luz Rimban, and Booma C. Cruz. The Rulemakers: How the Wealthy and Wellborn Dominate Congress Quezon City: Philippine Center for Investigative Journalism, 2004.

Courville, Sasha, and Nicola Piper. "Harnessing Hope through NGO Activism." Annals of the American Academy of Political and Social Science 592(2004):39-61.

Daenzer, Patricia. Regulating Class Privilege: Immigrant Servants in Canada, 1940s 1990s. Toronto: Canadian Scholars' Press Inc., 1993.

Daguio, Liza. "Family Still Number One." Tinig Filipino February 1995: 40.

Deparle, Jason. "A good provider is one who leaves." The New York Times 22 April 2007. 15 April 2008

$<$ http://query.nytimes.com/gst/fullpage.html?res=9D04E7D6113FF931A15757C0 A9619C8B63\&sec=\&spon=\&pagewanted $=2>$.

DFID/World Bank. International Conference on Migrant Remittances: Report and Conclusions', London, 2003.

Dhamoon, Rita. "Negotiating Citizenship: Migrant Women in Canada and the Global System." Labour 59(2007):267-269. 
Diamond, David "One nation, overseas." Wired.com June 10, 1999. April 15, 2008 $<$ http://wired.com/wired/archive/10.06>

Espiritu, Yen Le. Filipino America Lives. Philadelphia: Temple University Press, 1995.

Eviota, Elizabeth Uy. The political economy and gender, women and the sexual division of labour in the Philippines. London: Zed Books, 1992.

Flynn, Don, and Eleonore Kofman. "Women, Trade and Migration." Gender and Development, 12.2(2004):66-72.

"Filipino overseas worker remittances rise by 26 pct in March" People's Daily Online 15 May 2007. 27 Oct. 2007.

<http://english.people.com.cn/200705/15/eng20070515_374856.html>

Friedman-Kasaba, Kathie. Memories of Migration: Gender, Ethnicity and Work in the Lives of Jewish and Italian Women in New York, 1870-1924. Albany, NY: SUNY Press, 1996.

"Frequently asked questions: Working temporarily in Canada." Citizenship and Immigration Canada 31 Mar. 2007, 01 Dec. 2007.

$<$ http://www.cic.gc.ca/english/information/faq/work/caregiver-faq01 .asp>

Fudge, Judy. "Little Victories and Big Defeats: The Rise and Fall of Collective Bargaining Rights for Domestic Workers in Ontario" Not One of the Family: Foreign Domestic workers in Canada, Eds. Stasiulis, Daiva and Abigail B. Bakan. Toronto: University of Toronto Press, 1997.

Ghosh, Bimal. Migrants' remittances and development : myths, rhetoric and realities, International Organization for Migration, Geneva, Switzerland, Den Haag: the Hague Process on Refugees and Migration, 2006.

Gonzalez, Andrew. "Higher Education, Brain Drain and Overseas Employment in the Philippines: Towards a Differentiated Set of Solutions." Higher Education, 23.1(1992): 21-31.

Goss, Jon and Bruce Lindquist. "Conceptualizing International Labour Migration: A Structuration Perspective” International Migration Review 26.2(1995): 317-51.

Government of Canada Site. 26 October 2007. Government of Canada. Retrieved on 2007-10-26

$<$ http://www.canada.gc.ca/>

Human Development Reports. United Nations Development Programme. 26 Oct. 2007 $<$ http:/hdr.undp.org/reports/global/2001/en/clips/>. 
Gubert, F. "Migrant remittances and their impact on development in the home economies: The case of Africa." Migration, Remittances and Development. Paris: OECD, 2005.

Gutierrez, Bobby. "Solving the Root Cause of Poverty." Tinig Filipino January 1995:31.

Harris, Nigel. The New Untouchables: Immigration and the New Worker. London: B. Tauris and Company, 1995.

Holt, Elizabeth M. "Writing Filipina-Australian bodies: The discourse on Filipina brides." Philippine Sociological Review, 44(1996):58-78.

Hondagneu-Sotelo, Pierrette, and Ernestine Avila. "I am here, but I am there: The meanings of Latina transnational motherhood." Gender and Society 11.5(1997):548-571.

Huang, Shirley, and Brenda Yeoh. "Ties that Bind: State Policy and Migrant Female Domestic Helpers in Singapore." Geoforum, 27.4(1996): 479-493.

Iredale, Robyn. "Migration Policies for the Highly Skilled in the Asia-Pacific Region" International Migration Review, 34.3(2000):882-906.

Jong, G. F. D. "Expectations, gender, and norms in migration decision-making." Population Studies 54.3(2000):307-319.

Kassam, Ashifa. "Leaving family to keep them alive." CBC.ca 12 May 2006, 14 Jan 2008. <http://www.cbc.ca/news/viewpoint/vp_kassam/20060512.html>

Kapur, Devesh, and John McHale, "Migration's New Payoff." Foreign Policy, 139(2003): 48-57.

Keely, Charles B., and Bao Nga Tran, "Remittances from Labour Migration: Evaluations, Performance and Implications," International Migration Review, 23.3(1989):500525.

Lan Pei-Chia. "Bounded Commodity in a Global Market: Migrant Workers in Taiwan." Paper presented as the 1999 Annual Meeting of the Society for the Study of Social Problems, Chicago. 6-8 Aug. 1999.

---. "Maid or madam? Filipina migrant workers and the continuity of domestic labor." Gender and Society, 17.2(2003):187-208.

Lauby, J., and O. Stark. "Individual migration as a family strategy: Young women in the Philippines." Population Studies, 42.3(1988):473-486. 
Lim, L., and N. Oishi. "International Labour Migration of Asian Women: Distinctive Characteristics and Policy Concerns" Asian Women in Migration. Eds. G. Battistella and A. Paganoni. Quezon City: Scalabrini Migration Centre, 1996. 2353.

"Live-in Caregiver. Ontario Prevailing Wage Rates and Room and Board Rates, effective February 1, 2007." Ontario Provincial Government 15 February 2007, 26 Oct. $2007<$ http://www1.servicecanada.gc.ca/en/on/epb/fwp/lic.shtml>

"The Live-In Caregiver Program: How to Apply" Citizenship and Immigration Canada 31 Mar. 2007, 01 Dec. $2007<$ http://www.ci.gc.ca/english/work/caregiver/applyhow.asp>

"The Live-In Caregiver Program: Extending Your Stay" Citizenship and Immigration Canada 22 Jun 2007, 01 Dec. 2007

$<$ http:/www.cic.gc.ca/english/work/caregiver/extend-stay.asp $>$

Llorito, David. "Philippine Economy on the Mend," Asia Times Online, 26 Oct. 2006, 15 Apr. $2008<\mathrm{http}: / /$ www.atimes.com/Southeast_Asia/HJ26Ae01.html >

Lycklama, Geertje. "Trade in Maids: Asian Domestic Helpers in Migration Theory and Practice" Trade in Domestic Helpers: Causes, Mechanisms and Consequences. Kuala Lumpur: Asian and Pacific Development Centre, 1989. 21-62.

Mackey, Eva. The House of Difference: Cultural Politics and National Identity in Canada, London: Routledge, 1999.

Macklin, Audrey. "Foreign Domestic Worker: Surrogate Housewife or Mail Order Servant?" McGill Law Journal 37.3(1992):1

--. "On the inside looking in: Foreign domestic workers in Canada." Maid in the Market, eds. Wenona Giles and Sedef Arat-Koc. Halifax: Fernwood Publishing, 1994.

Makilan, Aubrey. "Filipina caregiver in Canada killed, another dream ending in tragedy." Bulatlat 7-13 Oct. 2007, 01 Dec. $2007<$ http://www.bulatlat.com/2007/10/filipinacaregiver-canada-killed-another-dream-ending-tragedy $>$

Margold, Jane A. "Narratives of masculinity and transnational migration: Filipino workers in the Middle East" Bewitching women, pious men: Gender and body politics in Southeast Asia.. Eds. A. Ong and M.G. Peletz. Berkeley: University of California Press, 1995.

Martin, Philip. "Migration and Trade: The Case of the Philippines." International Migration Review 27.3 (1993):639-45. 
Massey, D. S. "Social structure, household strategies, and the cumulative causation of migration." Population Index, 56.1(1990):3-26.

Montesano, Michael J. "The Philippines in 2003: Troubles, None of Them New" Asian Survey, 44.1(2004):93-101.

"More RP nurses are employed abroad," The Philippine Star. August 18, 1989:1

Naidu, V. Panel Discussion at Workshop on Asia-Pacific Migration: Will the Financial Crisis Represent a Turning Point? Australian National University, Canberra. 1718 Oct. 1998.

Ogaya, Chiho. "Social Discourses on Filipino Women Migrants" Feminist Review, 77(2004):180-182.

Organization for Economic Co-operation and Development (OECD). SOPEMI: Trends in International Migration: Continuous Reporting System on Migration, Annual report, 1997. Paris: OECD, 1998.

Organisation for Economic Co-operation and Development. Migrants' children and employment : The European experience. Paris, France; Washington, D.C.: Organisation for Economic Co-operation and Development; OECD Publications and Information Center, 1983.

Parikh, Rita. "I Could Put This House on Fire: The Everyday Resistance of Filipina Domestics in Canada," M.A. Thesis, Norman Paterson School of International Affairs, 1994.

Parrenas, Rhacel Salazar. "Human Sacrifices: What Happens When Women Migrate and Leave Families behind? The Case of the Philippines Raises Some Troubling Questions" The Women's Review of Books 19.5(2002): 16.

---. "Migrant Filipina Domestic Workers and the International Division of Reproductive Labour." Gender and Society 14.4(2000):560-580.

---. "Mothering from a Distance: Emotions, Gender and Intergenerational Relations in Filipino Transnational Families." Feminist Studies, 27.2(2001): 361-390.

---. Servants of Globalization: Women, Migration and Domestic Work. Stanford: Stanford University Press, 2001.

---. "Transgressing the Nation-State: The Partial Citizenship and 'Imagined (Global) Community' of Migrant Filipina Domestic Workers." Signs 26.4(2001):1129-1154. 
Paz Cruz, Victoria. Seasonal Orphans and Solo Parents: The Impacts of Overseas Migration, Quezon City, Philippines: Scalabrini Migration Centre, 1987.

Perlman, Daniel H. "Higher Education in the Philippines: An Overview and Current Problems." Peabody Journal of Education, 55.2(1978):119-126.

Pernia, Ernesto. "The Question of Brain Drain from the Philippines" International Migration Review, 10.1(1976):63-72.

The Philippines-Canada Human Resource Development Program. Uneven Gains. Ottawa: North-South Institute, 1996.

Philippine National Statistical Coordination Board. Women and Men in the Philippines. Makati City, Philippines: Philippine National Statistical Coordination Board, 1999.

Philippine Overseas Employment Administration 17 Feb. 2008, 15 Apr. 2008 $<$ http://www.poea.gov.ph/>

"Philippines: Political Killings, Human Rights, and the Peace Process" Amnesty International, 15 Aug. 2006, 15 Apr. 2008 <http://web.amnesty.org/library/Index/ENGASA350062006>.

"The Philippines." The World Factbook, Central Intelligence Agency. 15 April 2008 $<$ www.cia.gov/library/publications/the-world-factbook/geos/rp.html>

Plandano, Veronica. “Bayan, Kailan Pa?” Tinig Filipino October 1995:60.

Pratt, Geraldine. "BETWEEN HOMES: Displacement and Belonging for SecondGeneration Filipino-Canadian Youths," BC Studies, 140(Winter 2003/2004): 4167.

Quibria, M.G. "Migrant Workers and Remittances: Issues for Asian Developing Countries." Asian Development Review, 4.1(1986):78-99.

Ramirez, Judith. "Indentured Servitude." Rev. of Home Economics: Nationalism and the making of "Migrant Workers, by Nandita Sharma. Literary Review of Canada 14,2(2006):14-15.

Razack, Sherene H., "Introduction" Race, Space and the Law: Unmapping a White Settler Society. Ed. Sherene H. Razack. Toronto: Between the Lines, 2005. 1-20.

Global Commission on International Migration. Migration in an interconnected world: New directions for action. Switzerland: SRO-Kundig, October 2005.

Rodriguez, E. R. "International migrants' remittances in the Philippines." The Canadian 
Journal of Economics / Revue Canadienne d'Economique 29.2 (1996) : S427S432.

Rosca, Ninotchka. "The Philippines' Shameful Export.” Nation 260.15(1995):522-27.

San Juan E. Filipinos Everywhere: Displaced, Transported Overseas, Moving On in the Diaspora. Quezon City, Philippines: IBON Books, 2006.

Schecter, Tanya. Race, Class, Women and the State. Montreal: Black Rose Books, 1998.

Scott, Joan. "Experience." Feminists Theorize the Political, Eds. Judith Butler and Joan W. Scott. New York: Routledge, 1992. 22-40.

Sharma, Nandita. Home Economics: Nationalism and the making of "Migrant Workers" in Canada. Toronto: University of Toronto Press, 2006.

Smart, John E., Virginia A. Teodosio, and Carol J. Jimenez. "Skills and earnings: issues in the developmental impact on the Philippines of labour export" Asian Labour Migration: Pipeline to the Middle East. Eds. F. Arnold and N. M. Shaw. Boulder, CO: Westview Press, 1986. 101-124.

Stahl, Charles W., and Fred Arnold. "Overseas Workers' Remittances in Asian Development" International Migration Review 20.4(1986):899-925.

Stasiulis, Daiva, and Abigail B. Bakan. "Negotiating Citizenship: The case of foreign domestic workers in Canada." Feminist Review 57(Autumn 1997): 112-139.

Stasiulis, Daiva, and Abigail B. Bakan. Negotiating Citizenship: Migrant Women in Canada and the Global System. Toronto: University of Toronto Press, 2005.

Status of Women Canada. Canada's National Report to the United Nations for the Fourth World Conference on Women. Ottawa: Status of Women, September 1995.

"Study shows OFWs using 'materialistic approach' to child rearing." The Philippine Star 28 Jan. 2008: 15.

Suzuki, Nobue. "Between two shores: Transnational projects and Filipina wives in/from Japan." Women's Studies International Forum 23.4(2000):431-44.

Tadiar, Neferti Xina. "Domestic Bodies of the Philippines." Sojourn 12.2(1997):153-191.

Tan, Edita A., and Dante B. Canlas. "Migrants' saving, remittance and labour supply behaviour: The Philippines case." To the Gulf and Back: Studies on the Economic Impact of Asian Labour Migration. Ed. Rashid Amjad. Geneva: International Labour Office, 1989. 223-54. 
Taran, P. A. "Human rights of migrants: Challenges of the new decade." International Migration, 38.6(2000):7-51.

Tarcoll, Cecilia. "Migrating 'for the sake of the family?' Gender, life course and intrahousehold relations among Filipino migrants in Rome." Philippines Sociological Review 44.1-4(1996):12-32.

Taylor, J. Edward, Joaquin Arango, Graeme Hugo, Ali Kouaouci, Douglas S. Massey, and Adela Pellegrino. "International Migration and National Development." Population Index, 62.2(1996):181-212.

Taylor, J. E., J. Arango, G. Hugo, A. Kouaouci, D.S. Massey, and A. Pellegrino. "International Migration and Community Development" Population Index 62.3(1996):397-418.

Trinidad, Osteria. Filipino Female Labour Migration to Japan: Economic Causes and Consequences. Manila: De la Salle University Press, 1994.

Tolentino, Roland. "Bodies, Letters, Catalogues: Filipinas in Transnational Space" Social Text 48.14.3(1996): 49-76.

Tujan, Antonio."Health Professionals Migration and It's Impact on the Philippines." Asia Pacific Research Network 31 Mar. 2002, 24 Dec. 2007 $<$ http://www.aprnet.org/index.php?a=show\&t=journals\&i=5>

Tumolva, Cecilia, and Darla Tomeldan. "Domestic Workers and Caregivers' Rights: The Impact of Changes to BC's Employment Standards Regulation." Canadian Woman Studies. Special Issue: Benefiting Women? Women's Labour Rights, 23.3/4(2004): 153-156.

Tyner, James. "The Social Construction of Gendered Migration from the Philippines." Asian and Pacific Migration Journal 3.4(1994):589-615.

Tzvetkova, Marina. "NGO Responses to Trafficking in Women." Gender and Development, 10.1(2002): 60-68.

UNESCO. Living in two cultures : The socio-cultural situation of migrant workers and their families. Aldershot, England; Paris, France: Gower; Unesco Press, 1982.

UNESCO Statistical Yearbook, 1968, cited in Education for National Development. Report of the presidential Commission to Survey Philippine Education. Makati, Rizal, Philippines, December 1970.

United Nations. International Migration Policies and Programmes: A World Survey. New York: United Nations, 1982. 
Velasco, Pura. "Filipino migrant workers amidst globalization." Canadian Woman Studies (Spring/Summer 2002): 131-140.

--. " "We can still fight back," Not One of the Family: Foreign Domestic Workers in Canada. Eds. A. Bakan and D. Stasiulis. Toronto: University of Toronto Press, 1997. 157-164.

Veneracion, Connie. "Roots to Grow and Wings to Fly." Manila Standard Today 29 Jan. 2008: A5.

Villalba, May-An C. "Protecting Migrant Workers Rights: Government-NGO conflict and cooperation." Philippine Democracy Agency, Vol. 2. Eds. Marlon A. Wui and Ma. Glenda S. Lopez. (Quezon City: The Philippines: Third World Studies Centre, 1997).

Villaruz, Bing Cerdenola. “Should I Go or Should I Stay?” Tinig Filipino, 1995:62.

Weekley, Kathleen. "Saving pennies for the State: A new role for Filipino migrant workers?" Journal of Contemporary Asia 01-04 Aug. 2004. 1.

Wong, Sau-Ling. "Diverted mothering: Representations of caregivers of color in the age of "multiculturalism." Mothering: Ideology, experience and agency. Eds. E.N. Glenn, G. Chang and L. Rennie Forcey. New York: Routledge, 1994.

"Working temporarily in Canada: The Live-In Caregiver Program" Citizenship and Immigration Canada 31 March 2007, 26 Oct. 2007 $<$ http://www.cic.gc.ca/English/work/caregiver/index.asp>

World Bank. Global Economic Prospects: Economic Implications of Remittances and Migration, 2006. Washington, D. C: World Bank, 2005.

World Bank. From Plan to Market: World Development Report 1996 New York: Oxford University Press, 1996.

Yeoh, Brenda S.A., Shirlena Huang, and Joaquin Gonzalez III. "Migrant Female Domestic Workers: Debating the Economic, Social and Political Impacts in Singapore.” International Migration Review 33.1(1999):114-36.

Yeoh, Brenda S., and Shirlena Huang. "Singapore women and foreign domestic workers: Negotiating domestic work and motherhood" Gender, migration and domestic service, Ed. J. H. Momsen. New York: Routledge, 1999.

Young, J. P. "Intimate allies in migration: Education and propaganda in a Philippine village" Comparative Education Review 26.2(1982):218-234. 
Zlotnick, Hania. "The South-to-North Migration of Women." International Migration Review 29.1(1995):229-54. 